UNIVERSIDADE DE SÃO PAULO

FACULDADE DE ECONOMIA, ADMINISTRAÇÃO E CONTABILIDADE DEPARTAMENTO DE ADMINISTRAÇÃO PROGRAMA DE PÓS-GRADUAÇÃO EM ADMINISTRAÇÃO

TESE DE DOUTORADO

SOCIEDADE COOPERATIVA DE PRODUÇÃO AGROPECUÁRIA:ESTUDO DOS GANHOS INDIRETOS DOS COOPERADOS

Pedro Einstein dos Santos Anceles

Orientador: Prof.-Dr. Cláudio Antônio Pinheiro Machado Filho

SÃO PAULO 


\title{
SOCIEDADE COOPERATIVA DE PRODUÇÃO AGROPECUÁRIA: ESTUDO DOS GANHOS INDIRETOS DOS COOPERADOS
}

\author{
Tese apresentada ao Departamento de \\ Administração da Faculdade de \\ Economia, Administração e \\ Contabilidade da Universidade de São \\ Paulo como requisito parcial para \\ obtenção do título de Doutor em \\ Ciências. \\ Orientador: Prof.-Dr. Cláudio \\ Antônio Pinheiro Machado Filho
}

Versão Corrigida

(versão original disponível na Faculdade de Economia, Administração e Contabilidade)

São Paulo 
Prof.-Dr. Marco Antonio Zago Reitor da Universidade de São Paulo

Prof.-Dr. Adalberto Américo Fischmann

Diretor da Faculdade de Economia, Administração e Contabilidade

Prof.-Dr. Roberto Sbragia

Chefe do Departamento de Administração

Prof.-Dr. Moacir de Miranda Oliveira Júnior Coordenador do Programa de Pós-Graduação em Administração 

DOS GANHOS INDIRETOS DOS COOPERADOS

Tese apresentada ao Departamento de Administração da Faculdade de Economia, Administração e Contabilidade da Universidade de São Paulo como requisito parcial para obtenção do título de Doutor em Ciências.

Orientador: Prof.-Dr. Cláudio Antônio Pinheiro Machado Filho

\section{SÃO PAULO}


FICHA CATALOGRÁFICA

Elaborada pela Seção de Processamento Técnico do SBD/FEA/USP

Anceles, Pedro Einstein dos Santos

Sociedade cooperativa de produção agropecuária: estudo dos ga-

nhos indiretos dos cooperados / Pedro Einstein dos Santos Anceles. --

São Paulo, 2014.

$172 \mathrm{p}$.

Tese (Doutorado) - Universidade de São Paulo, 2014.

Orientador: Cláudio Antônio Pinheiro Machado Filho.

1. Cooperativas 2. Governança corporativa 3. Ambiente institucional 4. Direito de propriedade 5. Bem-estar econômico e social 6. Ganho indireto do cooperado I. Universidade de São Paulo. Faculdade de Economia, Administração e Contabilidade. II. Título.

CDD -658.047 


\section{AGRADECIMENTOS}

Agradeço à Universidade Federal de São Paulo, Faculdade de Economia, Administração e Contabilidade (FEA-USP), em particular, ao Curso de Administração, pela possibilidade ímpar de realizar e concluir as atividades de estudos, pesquisas e aprimoramentos para obtenção do título acadêmico de Doutor em Administração.

Sou grato ao Curso de Administração da Universidade Federal de Santa Maria (RS) por testemunhar o grande esforço em promover o DINTER, demonstrando o compromisso em oportunizar a busca do conhecimento científico em prol do aperfeiçoamento dos docentes e para o atendimento da demanda dos alunos da instituição.

Agradeço, também, a todos os professores do DINTER e ao Prof.-Dr. Decio Zylbersztajn, pela orientação inicial e a toda a equipe do PENSA que, de maneira incansável, me auxiliou para bem cumprir as tarefas de pesquisa, ensino e acompanhamento acadêmico.

Faço um agradecimento especial ao meu orientador, Prof.-Dr. Cláudio Antônio Pinheiro Machado Filho, que não mediu esforços no sentido de proporcionar uma excelente orientação acadêmica para a obtenção do título de doutor.

Agradeço, outrossim, às sociedades cooperativas de produção agropecuárias e agroindustriais do Estado do Rio Grande do Sul, em nome do Dr. Alcenor Pagnussatt, que atenderam à solicitação de pesquisa e prestaram importantes informações. Obrigado aos técnicos, dirigentes e cooperados, tanto àqueles que foram incluídos na efetivação da pesquisa, quanto aos demais não mencionadas neste relatório.

A minhas filhas, Eliana Karsten Anceles e Elisângela Karsten Anceles, que sempre estiveram a meu lado, ofertando-me o apoio necessário para a conquista do conhecimento.

A minha esposa Lídia Anceles, deixo meu reconhecimento pela companhia que me fez nas várias etapas do curso de Doutorado, sempre com o propósito de me auxiliar a atingir o objetivo final.

E por fim, agradeço à fé divina, como semente que caiu em boa terra, vem produzindo frutos cada vez melhores. 


\section{RESUMO}

A tese discute o tema contemporâneo do ganho indireto dos cooperados de sociedades cooperativas de produção agropecuária e agroindustriais. Procura responder por quais diferentes maneiras essas organizações adicionam valor econômico aos cooperados, e mostra como os cooperados percebem as diferentes categorias de benefícios econômicos e não econômicos. Foi realizada análise da cooperação na linha teórica da Nova Economia Institucional (NEI), com ênfase no mapeamento das percepções econômicas e não econômicas dos cooperados nas relações existentes com a sociedade cooperativa de produção agropecuária e, ainda, na ótica da teoria da renda, com a análise dos benefícios econômicos e sociais do cooperado produtor rural, pessoa física dentro da sociedade cooperativa de produção agropecuária. Para o estudo de caso, utilizaram-se entrevistas com técnicos especializados, como fonte de informações e aplicação de questionários aos cooperados, cuja finalidade foi extrair dados qualitativos das sociedades cooperativas de produção agropecuárias e agroindustriais, de objetos sociais variados, localizadas no Estado do Rio Grande do Sul. Constataram-se transferências indiretas pelas sociedades cooperativas que são percebidas pelos cooperados, na forma de ganhos pecuniários e não pecuniários. Os ganhos não pecuniários são relacionados ao status, conforto, conhecimento, segurança, entre outros, descritos como privilégios no âmbito dessas organizações. Tais ganhos não são voltados ao aumento de riqueza, mas contribuem para o aumento do bem-estar de todos os cooperados. Então, em última análise, é possível concluir que os cooperados percebem os ganhos indiretos das mais variadas formas, principalmente pela melhoria do bem-estar econômico e social.

Palavras-chave: Cooperativa agropecuária. Cooperados. Ganho indireto. Ganho nãoeconômico. Estudo de caso. 


\begin{abstract}
The thesis discusses a contemporary theme on the indirect gain of members of the agricultural production cooperative society. It seeks to answer by which different ways these organizations add economic value to the cooperative member and shows how the members realize the various categories of economic and non-economic benefits. An analysis of cooperation was conducted under the theoretical framework of the New Institutional Economics - NIE, emphasizing the mapping of economic and noneconomic perceptions of the existing cooperative relations with agricultural production cooperative society and yet from the perspective of the theory of income, analysis of the economic and social benefits of the cooperative member rural producer as individual into the cooperative agricultural production. To the case study, it were used as a source of information interviews with technical experts and applied questionnaires to cooperative members, viewing to obtain qualitative data of agricultural and agroindustrial production cooperative societies, of various corporate social purposes, located in the state of Rio Grande do Sul, Brazil. Forms of indirect transfers from cooperative societies were detected, which are perceived by the cooperative members as pecuniary and non-pecuniary gain. The non-pecuniary gain is related to status, comfort, knowledge, security among others, described as privileges within those organizations.

These gains are not geared to increasing wealth, but contribute to increase the wellbeing of all cooperative members. Therefore, in the end, one can conclude that the cooperative members realize the indirect gains in the most variable ways, mainly by improving economic and social well-being.
\end{abstract}

Keywords: Agricultural Cooperative. Cooperative members. Non-economic gain. Indirect transfer. Case study. 


\section{SUMÁRIO}

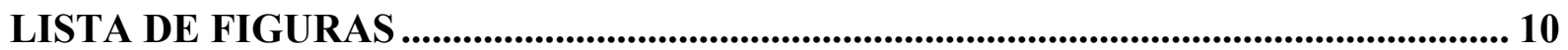

LISTA DE QUADROS ................................................................................................... 11

1 INTRODUÇÃ O ............................................................................................................... 12

1.1 Apresentação em linhas gerais da pesquisa............................................................ 12

1.2 O problema de pesquisa ..........................................................................19

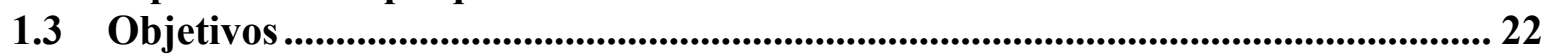

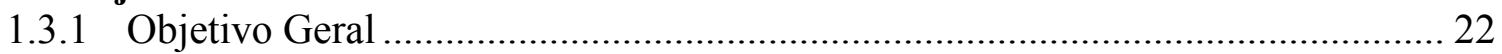

1.3.2 Objetivos Específicos .............................................................................. 22

1.4 Estrutura da Tese.............................................................................................................. 23

2 A COOPERAÇÃO E SUAS PARTICULARIDADES................................................. 26

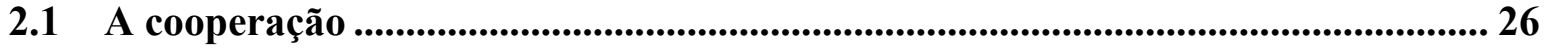

2.20 ambiente institucional .............................................................................................. 34

2.3 A dimensão do direito de propriedade................................................................. 38

2.4 Sociedade cooperativa de produção agropecuária ...................................................... 42

2.4.1 A Firma e suas Particularidades .................................................................... 42

2.4.2 O Tamanho da Firma.................................................................................... 47

2.5 Competitividade das sociedades cooperativas ...................................................5 50

2.5.1 Fundamentos da competitividade .................................................................. 52

3 A SOCIEDADE COOPERATIVA DE PRODUÇÃO AGROPECUÁRIA E SUA

CAPACIDADE DE GERAR RENDAS ............................................................................56

3.1 Patrimônio líquido das sociedades cooperativas.......................................................... 56

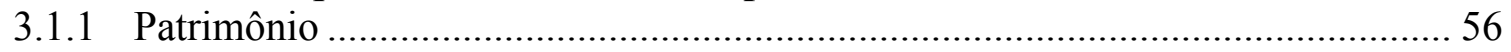

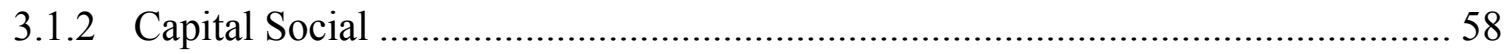

3.1.3 Demonstração do Resultado do Exercício............................................................. 60

3.1.4 Lucros ou Prejuízos Acumulados ......................................................................... 64

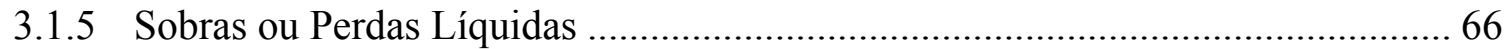

3.1.6 Ajustes de Avaliação Patrimonial .................................................................. 72

3.2 Sociedade cooperativa e a geração de resultado econômico e financeiro .............. 73

3.2.1 Ganhos competitivos de eficiência .................................................................... 75

4 O COOPERADO PESSOA FÍSICA E A TEORIA DA RENDA................................... 88

4.1 A renda do cooperado pessoa física produtor rural ................................................... 88

4.2 A Renda auferida pelo cooperado .............................................................................. 89

4.2.1 Teoria da Renda e sua Mensuração .................................................................... 89

4.3 Geração de valor econômico para o cooperado pessoa física ................................. 95

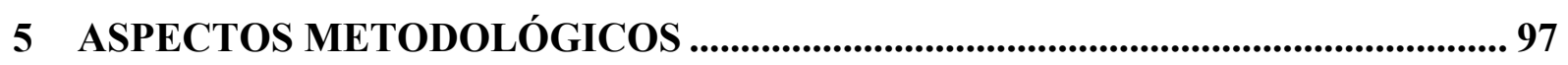

5.1 Sociedade Cooperativa Agroindustrial "A"

5.2 Sociedade Cooperativa Agroindustrial "B" ................................................................. 98

5.3 Sociedade Cooperativa Agroindustrial " $\mathrm{C}$ " .................................................................. 98

5.4 Sociedade Cooperativa Agroindustrial "D" ............................................................98

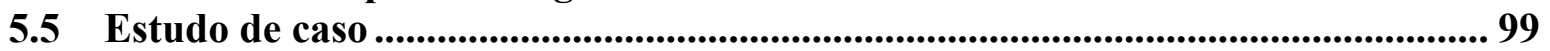

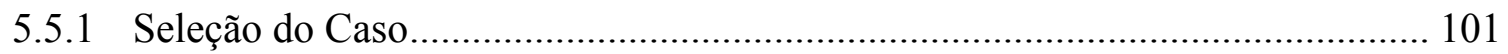

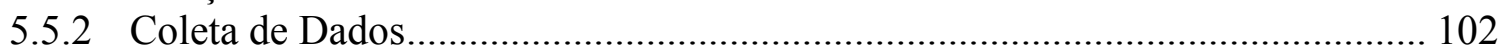

5.6 Questões de pesquisas......................................................................................................... 103 


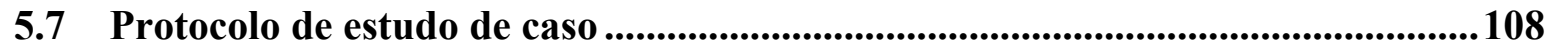

6 ANÁLISE E DISCUSSÃO DO RESULTADO..........................................................112

6.1 As sociedades cooperativas no contexto da análise ..............................................112

6.1.1 Sociedade Cooperativa Agroindustrial "A" ......................................................... 112

6.1.2 Sociedade Cooperativa Agroindustrial "B" ......................................................... 112

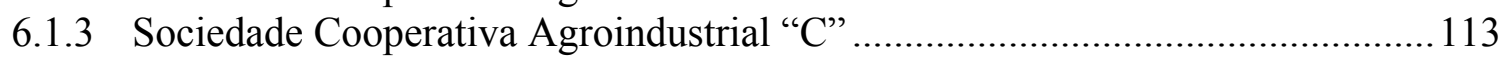

6.1.4 Sociedade Cooperativa Agroindustrial " $D$ " ..................................................... 113

6.2 O ambiente competitivo das sociedades cooperativas..........................................114

6.3 É visível o instituto da cooperação? ................................................................119

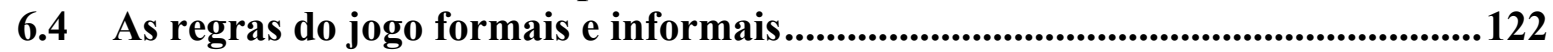

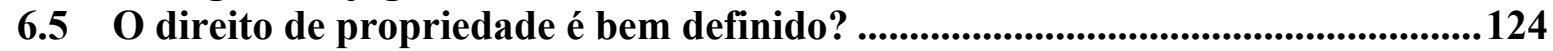

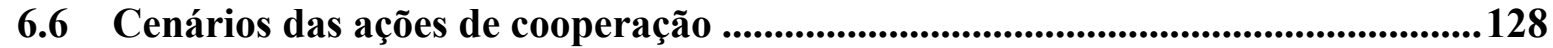

6.7 Sociedades cooperativas e ganhos indiretos dos cooperados...............................133

6.8 Mapeamento das percepções econômicas e não-econômicas dos cooperados.... 141

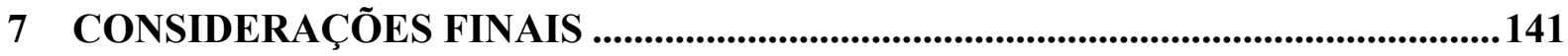

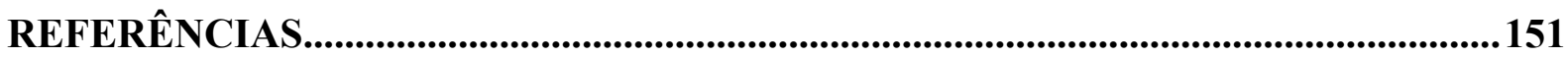

APÊNDICE 1 - Roteiro de entrevista para técnicos especializados ..............................162

APÊNDICE 2 - Questionário aplicado a cooperados pessoa física .................................164

APÊNDICE 3 - Termo de Consentimento de Livre Esclarecimento (TCLE)................170 


\section{LISTA DE FIGURAS}

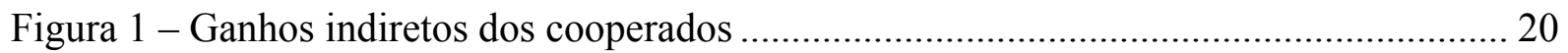

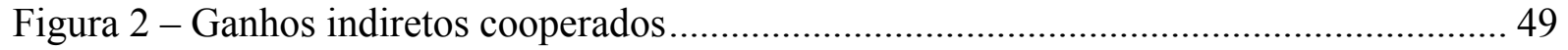

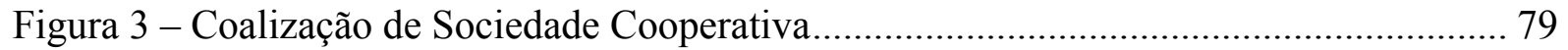

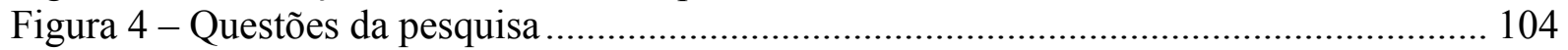

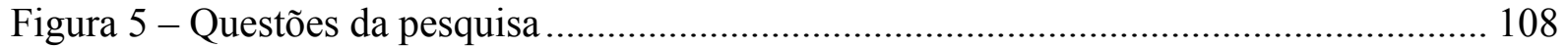

Figura 6 - Sociedades Cooperativas: geração de rendas e ganhos indiretos. ....................... 116

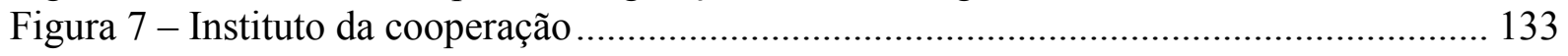

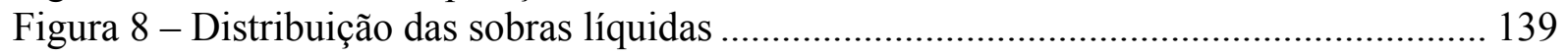




\section{LISTA DE QUADROS}

Quadro 1 - Principais contas de patrimônio líquido da sociedade cooperativa .......................57

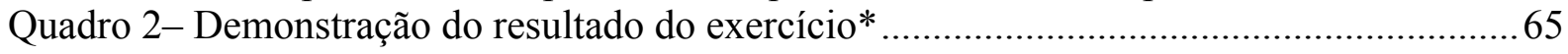

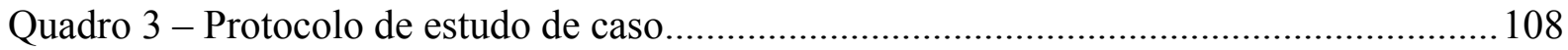

Quadro 4 - Solidariedade, finalidade social e econômica.................................................. 118

Quadro 5 - Cooperação e relação contratual ....................................................................... 119

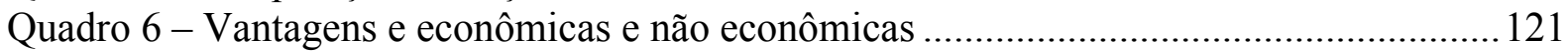

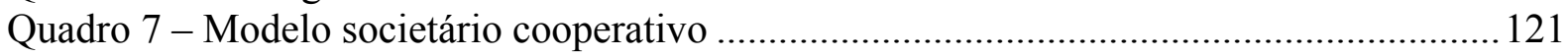

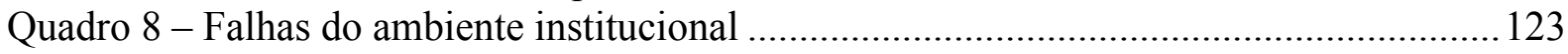

Quadro 9 - Direito de propriedade ............................................................................ 125

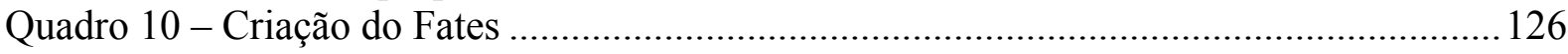

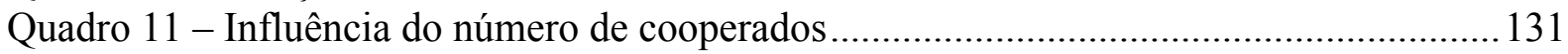

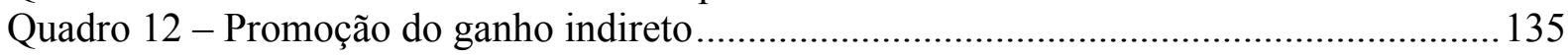

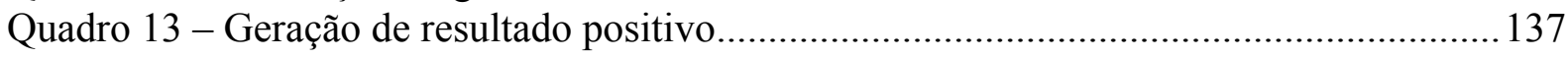

Quadro 14 - Capacidade de geração de resultado ................................................................ 138 


\section{INTRODUÇÃO}

\subsection{APRESENTAÇÃO EM LINHAS GERAIS DA PESQUISA}

A tese apresenta como título: "Sociedade cooperativa de produção agropecuária: estudo dos ganhos indiretos dos cooperados". E a questão central do estudo consiste em saber: Por quais diferentes maneiras, a sociedade cooperativa de produção agropecuária, inclusive a agroindustrial, adicionam valor econômico e social indireto para o cooperado, no espaço temporal anual em que se desenvolvem as atividades operacionais dessa organização?

O tema pesquisado é contemporâneo e apresenta empatia, bem como interesse dos integrantes das organizações cooperativas. A matéria é complexa, mas desperta curiosidade de pesquisadores, da comunidade científica em geral e demais entidades públicas e privadas.

Em consonância com os princípios cooperativos, a sociedade cooperativa de produção agropecuária, inclusive a agroindustrial, apresenta como escopo a solidariedade social e a comunhão de interesses, cuja finalidade é a prestação de serviços aos cooperados. Assim, esta organização, de cunho eminentemente comunitária, ganha o merecido relevo no ambiente econômico, procurando realizar uma justa e equitativa distribuição da riqueza produzida aos cooperados.

A exteriorização das atividades, meios e fins repercutem, economicamente, como atividades operacionais ou negociais. Ela diz respeito ao vínculo que rege os negócios internos entre os cooperados da sociedade cooperativa, bem como aos negócios externos, contratados por terceiros, caracterizados pelas operações de industrialização, compra e venda de produtos com respaldo contratual. A organização visa aos mesmos fins, ao assegurar ao cooperado a busca pelo preço justo dos seus produtos, eliminando, ao colocá-los no mercado, a etapa lucrativa repassada ao próprio cooperado.

O modelo societário, inclusive seu enquadramento como sociedade de pessoas e não de capital, direciona as atividades com o intuito de promover ganho direto aos cooperados, quantificado pelo aumento de rendimentos e receitas ou pela redução de custos e despesas, resultando em aumento de produção e produtividade e, consequentemente, melhor 
comercialização dos produtos agropecuários. Simultaneamente, pode proporcionar ganho indireto, de melhoria econômica qualificada pelo desenvolvimento de várias atividades realizadas pela organização, como assistência técnica e profissional, extensão rural e aquelas decorrentes de serviços prestados em benefício comum dos cooperados, ou seja, sempre com o foco em negócios agropecuários, desenvolvidos pela entidade.

O ganho indireto do cooperado, decorrente da aprendizagem que, em parte resulta da economia, da escala de produção rural, pode ser definido como uma modalidade de renda, sendo externalizado pela melhoria do bem-estar social. E, ainda, esse ganho tem como consequência lógica e principal, a melhoria de qualidade dos produtos agropecuários, enviados à sociedade cooperativa de produção agropecuária, a fim de que sejam industrializados para futura comercialização.

Na mesma linha de raciocínio, Besanko et all (2006) ensinam que, embora haja pouco estudo sistemático sobre as determinantes da aprendizagem, um pouco de bom senso ajuda a identificar situações em que a aprendizagem é mais importante. Isso depende das pessoas, e as empresas podem facilitar a adoção e o uso de ideias recém-aprendidas, encorajando o compartilhamento de informações e estabelecendo regras de trabalho que incluam as novas ideias. Ou seja, um meio de ganho indireto do cooperado pode ser decorrente da aprendizagem ofertada pela sociedade cooperativa de produção agropecuária.

Para Marjorie Lyles (1998), o pressuposto básico da aprendizagem organizacional é que o conhecimento pode ser transferido entre indivíduos, equipes e unidades organizacionais. A estrutura dessas organizações inclui armazenamento do sistema de crenças, das memórias de eventos passados, de histórias, de modelos referenciais ou de valores. Para a autora, a aprendizagem é dinâmica e há mudanças constantes nos seus níveis, como também um fluxo contínuo que se autorreproduz. A autora conclui pela existência de quatro pontos de destaque sobre a aprendizagem:

Primeiro é que ela está baseada na percepção, ou seja, é normal particularmente para o conhecimento tácito, desde que as pessoas não o entenderão ou o perceberão do mesmo modo; segundo, o conhecimento explícito pode ser conquistado e codificado, e muitas vezes estão tentando, na medida do possível, documentar esse conhecimento de nível mais baixo com sistema de informação; terceiro, a aprendizagem depende de modelos mentais compartilhados, ou seja, de modelos de referência comuns que filtram e 
armazenam a entrada de informação; e quarto, o envolvimento ativo dos participantes. (MARJORIE LYLES, 1998)

Estudo realizado por Johnson, et al (2000), demonstra que a aprendizagem cooperativa promove efeitos cognitivos positivos, nomeadamente, fomenta o rendimento em todas as áreas e níveis de ensino, melhora a consecução de tarefas que implicam a aquisição de conceitos, a solução de problemas, a retenção, a memória e o desenvolvimento de tarefas de suposição e predição. Logo, a cooperação promove maior produtividade e obtenção de sucesso que a competição ou os esforços individualistas que os cooperados possam fazer. A transferência das aprendizagens, isto é, a aplicação a novas situações é mais facilitada quando os cooperados trabalham cooperativamente.

Para Gillies (2007), a aprendizagem cooperativa incrementa, antes de mais nada, o respeito mútuo, a solidariedade, os sentimentos recíprocos de obrigação e entreajuda, assim como a capacidade de adotar perspectivas comuns. Outro efeito marcante é o incremento da autoestima nos cooperados, incluindo aqueles que revelam um baixo rendimento. Essa espécie de aprendizagem tem sido aplicada nas ciências sociais.

Em resumo, a aprendizagem pode ser definida como um processo no qual a repetição e a experimentação fazem com que, ao longo do tempo, as tarefas sejam efetuadas de forma mais rápida e melhor, e que as novas oportunidades operacionais sejam efetivamente experimentadas. Ela é cumulativa e coletiva e depende, fundamentalmente, de rotinas organizacionais, codificadas e tácitas. E pode até ser um dos fatores responsáveis do bemestar dos cooperados integrantes das sociedades cooperativas analisadas no presente estudo.

Neste contexto, o problema já identificado resta ainda saber: Diante da existência de ganhos socioeconômicos indiretos de caráter não financeiro, como esses benefícios econômicos e não econômicos são percebidos pelos cooperados, pessoas físicas, produtores rurais, decorrentes das transferências realizadas pela sociedade cooperativa de produção agropecuária?

Sabe-se que é nesse contexto que a percepção dos benefícios chega aos cooperados. A terminologia está presente nas relações com a sociedade cooperativa. Ela é fundamental para 
que os indivíduos tomem ciência das mudanças causadas no ambiente pelas ações dos participantes (NEISSER, 1976).

As ações que normalmente fazem parte de um plano para atingir uma meta, também podem ser guiadas por elementos de percepção. Para Shimizu (1980), a percepção é vista como sensibilidade intuitiva e capacidade de obter entendimento instantâneo de toda a estrutura da nova informação. Assim, os elementos de percepção transmitem as mudanças de planos, contribuindo para gerar o novo entendimento. Além disto, podem alertar os participantes de aspectos temporais e espaciais de suas ações e facilitar a sincronização das tarefas individuais.

Por sua vez, o cooperativismo inspira-se no princípio da solidariedade social e na comunhão de certos interesses, tendo como objetivo a melhoria das condições socioeconômicas dos cooperados, conforme a Lei $n^{\circ} 5.764$, de 1971, art. $4^{\circ}$ (BRASIL, 1971). Em 1995, sob a supervisão da Aliança Cooperativa Internacional (ACI, 2014), foram traçadas as linhas orientadoras pelas quais as sociedades cooperativas levam à prática seus valores. A sociedade cooperativa pode se constituir em causa social e econômica, visando à justa e equitativa distribuição da riqueza aos cooperados, ainda que produzida ao longo do tempo.

Para Aranzadi (1987), os instrumentos de ação que a sociedade cooperativa utiliza para atingir objetivos, têm sido a busca de combinação de fatores produtivos, com o fim de obter produtos e serviços aliados à racionalidade econômica, para que se efetive o máximo de produção agropecuária, mesmo que seja com os recursos limitados, sem que ocorra prejuízo financeiro. Daí decorre que as sociedades cooperativas devem ter mecanismos para atingir essa meta, a começar pelos ganhos de especializações ou inovações, quando os cooperados adquirem maior habilidade profissional, tornando-se qualificados e eficientes, gerando pois menores custos para a organização. Tais mecanismos podem ter resultados distintos daqueles adotados pelas empresas de propriedade de investidores, denominadas de sociedades de capitais, revestidas principalmente na forma de sociedades anônimas.

Do ponto de vista econômico, Franke (1973) define a sociedade cooperativa como uma organização societária de pessoas, de caráter auxiliar, por cujo intermédio uma comunidade de produtores rurais promove, em comum acordo, a defesa com melhorias e incrementos da economia individual. Essa defesa pode ser realizada, substancialmente, pelo produtor rural que se utiliza da sociedade cooperativa de produção agropecuária para industrializar e 
comercializar produtos agropecuários no mercado interno e externo, mas não apenas isso. É uma das finalidades da organização o apoio aos produtores rurais na realização das transações, objetivando a redução de custos, contrabalançando o eventual poder de mercado das empresas vendedoras de insumos, bens e serviços, ou das processadoras dos produtos agropecuários da cadeia produtiva. Isso vem permitir o equilíbrio necessário nos preços e a adequação do ganho de escala.

As sociedades cooperativas estão situadas em um plano entre a economia particular dos cooperados, de um lado, e o mercado, de outro, aparecendo como estruturas singulares intermediárias que agregam interesses comuns. Ressalte-se, ainda, que essas organizações não possuem, do ponto de vista econômico, uma existência autônoma e independente dos cooperados, como ocorre normalmente nas sociedades empresariais. Elas surgem, no entanto, como organizações intermediárias, postas a serviço da satisfação das necessidades econômicas dos próprios cooperados. Para o Franke (1973), é importante a explicação sobre o negócio-fim e negócio-meio:

As sociedades cooperativas agrícolas de venda em comum têm por fim receber os produtos dos cooperados, para colocá-los no mercado consumidor. A entrega do produto, feita pelo cooperado à sociedade cooperativa agrícola, é um negócio interno, um negócio-fim, noutras palavras, um ato cooperativo. Mas a venda que a sociedade cooperativa agrícola fizer do produto, no mercado, é um negócio externo, um negócio-meio, um negócio de contrapartida, que ela necessita realizar como objeto de sua atividade, a fim de completar o serviço devido ao cooperado mediante a transmissão que lhe fizer do preço de venda do produto, após deduzidas as despesas operacionais (FRANKE, 1973, p. 24).

No plano institucional, porém, a sociedade cooperativa procura transcender o perfil capitalista e tenta firmar-se com a ideia de que não é essencial o escopo lucrativo para caracterizá-la. A união de pessoas físicas constitui a base orgânica da sociedade cooperativa, em contraposição, e até com certa indiferença, à sociedade de capital.

$\mathrm{Na}$ esteira dessa linha teórica, torna-se necessário então fazer a distinção entre o fim (causa final) da sociedade cooperativa e o objeto. O fim da sociedade cooperativa é a prestação de serviços ao cooperado para melhorar sua condição socioeconômica; e o objeto do empreendimento cooperativo é o ramo de atividade, ou seja, o meio pelo qual a sociedade cooperativa procura alcançar a finalidade, a defesa e a melhoria da situação socioeconômicada do cooperado. Em outras palavras, o escopo da função objetiva da sociedade cooperativa depende dos objetivos individuais de cada membro ou sócio (COOK, 1994). 
Hendrikse (2007) faz uma distinção pertinente entre a sociedade empresarial e sociedade cooperativa do setor agroalimentar com o alcance na dimensão da transação, ou seja, os proprietários da sociedade cooperativa (e de suas unidades industriais, no caso de uma sociedade cooperativa agroindustrial) são também os fornecedores de matéria-prima e/ou compradores de insumos. Como a sociedade é um arranjo institucional voltado para o cooperado e não para o lucro do investidor, como nas sociedades empresariais. Beverland e Lindgreen (2007) suscitam uma questão muito importante: é ou não é necessário modificar a estratégia e a estrutura da sociedade cooperativa, de modo que ela se torne mais voltada para o mercado.

Para Cechin (2014) entre os diferentes arranjos, as sociedades cooperativas enfrentam desafios particulares para se adaptarem às novas realidades dos mercados agrícolas contemporâneos em razão de sua arquitetura organizacional. O cooperados têm uma relação tríplice com a sua cooperativa Barton, (1989): de transação (uso), de propriedade e de controle.

Em relação à sociedade cooperativa de produção agropecuária, a melhoria econômica e financeira do cooperado pode resultar, de forma direta, no aumento de rendimentos e receitas, ou redução de custos e despesas. Indiretamente, pode haver uma melhoria econômica, decorrente de aprendizagem do cooperado, por meio de prestação de assistência técnica e extensão rural, pelos serviços prestados, através de incorporação de programas operacionais e inovações tecnológicas, projetadas em benefício comum dos cooperados, com foco em negócios agropecuários desenvolvidos pela organização. E, ainda, podem advir vantagens decorrentes da assistência profissional e assemelhadas, a realização de cursos, palestras, treinamentos, informações econômicas do mercado e eventos, em geral, destinados aos cooperados para melhoria dos processos de produção agropecuária. É nesse sentido, a orientação trazida pelo órgão regulador:

A assistência técnica e a extensão rural são serviços de importância fundamental no processo de desenvolvimento rural e da atividade agropecuária. Têm importância fundamental no processo de comunicação de novas tecnologias, geradas pela pesquisa, e de conhecimentos diversos, essenciais ao desenvolvimento rural no sentido amplo e, especificamente, ao desenvolvimento da atividade agropecuária, florestal e pesqueira. A assistência técnica e a extensão rural buscarão viabilizar, com o produtor rural, sua família e organização, soluções adequadas para os problemas de 
produção, gerência, beneficiamento, armazenamento, comercialização, industrialização, eletrificação, consumo, bem-estar e preservação do meio ambiente (BANCO CENTRAL DO BRASIL, Resolução nº 3.239, 2004).

O ganho de especialização do cooperado pode influenciar a economia de escala e, consequentemente, ser um dos fatores determinantes para aumento do ganho direto financeiro, seja pela qualidade e produtividade, seja pela competitividade do produto industrializado e comercializado ou seja pela sociedade cooperativa. Esse ganho difere da economia de aprendizagem.

De acordo com Besanko et alii (2006, p. 6), as economias de aprendizagem são diferentes da economia de escala. A economia de escala constitui a capacidade de realizar uma atividade com menor custo unitário, buscando uma escala maior em determinado momento; já a economia de aprendizagem refere-se à redução de custo unitário devido à experiência acumulada no tempo.

Nesse contexto, não pode ser desprezada a melhoria do bem-estar social do cooperado, externado pelo valor econômico do uso da tecnologia, assim como pela melhoria da capacidade e conhecimento intelectuais, para transformar ideias criativas a fim de otimizar qualidade e produtividade nos produtos agropecuários.

Ademais, observa-se que pode haver atividades com geração de valor para o cooperado decorrente de provimento de rede de segurança em períodos de crise econômica, entre outras. Assim, o cooperativismo pode permitir que a sociedade cooperativa, principalmente o cooperado, se aproprie de uma parcela expressiva de benefícios indiretos, de fatores de produção como produtos, antes transferidos para grupos concentrados em função das características dos mercados, como a estrutura oligopolista e monopsonista. ${ }^{1}$ A partir das

\footnotetext{
${ }^{1} \mathrm{O}$ monopsônico é caracterizado pela existência de muitos vendedores e um único comprador. É uma estrutura que pode prevalecer especialmente no mercado de trabalho (TROESTER, 2004, p. 198). O poder monopsônico possibilita ao comprador adquirir a mercadoria por valor inferior ao preço que prevaleceria em um mercado competitivo (PINDYCK; RUBINFELD 2010, p. 329). O oligopsônico é o mercado em que existem poucos compradores que dominam o mercado e muitos vendedores (TROESTER, 2004). Com base nos elementos essenciais da estrutura de mercado, notadamente o número de empresas e a diferenciação do produto, os mercados podem ser classificados como: competitivos (concorrência pura, monopolística e monopsônica), pouco competitivos (oligopólios e oligopsônicos) e sem competição (monopólio e monopsônico). A agricultura em si é perfeitamente competitiva, uma vez que qualquer produto agrícola, além de ser homogêneo, é produzido por um grande número de produtores e sem barreiras à entrada de novos produtores no mercado. Contudo, os agricultores, ao se relacionar com o setor não agrícola (isto é, agroindustrial), enfrentam situações de oligopólios e oligopsônicos e até monopólios e monopsônicos (MENDES, 2007. p. 178).
} 
aspirações puramente econômicas dos cooperados, que se mesclam às aspirações sociais, a sociedade cooperativa pode alcançar os objetivos e finalidades.

A prestação de serviços pode permitir a prática de operações para facilitar ou auxiliar o exercício das atividades econômicas e negociais dos cooperados, que se apresentam sob o manto das atividades agropecuárias. Disso resulta a compreensão de que a sociedade cooperativa, constituída por pessoas de determinado grupo social ou econômico, pode realizar atividades relevantes dentro do segmento econômico, com a redução de custos empresariais, manutenção e diminuição do nível de preços, economia de escala e de escopo, assim como superação de dificuldades e imperfeições de mercado. E, ainda, pode decorrer da relação contratual entre os cooperados que, reciprocamente, se obrigam a contribuir com bens ou serviços que, na sua essência, revelam a natureza mutualista, sem objetivo de lucro.

Nesse contexto, impende acrescentar as ponderações de Nascimento (2000), quando afirma que não são claros aos cooperados, que têm apenas motivações pessoais no início do processo de participação na organização, que são a educação e a informação qualificada, os elementos impulsionadores para que a cooperação, via entidade cooperativa, atinja estágios importantes de desenvolvimento qualitativo da pessoa humana. Ademais, o necessário comportamento racional deve ser entendido pelo desejo de os cooperados melhorarem as condições de vida, podendo se juntar ao comportamento solidário, para que simultaneamente possam ser alcançados os modelos redistributivos, que é um dos objetivos perseguidos pela sociedade cooperativa.

$\mathrm{Na}$ linha deste construto, a questão central do presente estudo parte das diferentes maneiras pelas quais a sociedade cooperativa de produção agropecuária adiciona valor econômico e social para o cooperado, no espaço temporal anual em que se desenvolvem as atividades operacionais da organização.

\subsection{O PROBLEMA DE PESQUISA}

O atributo que mais diferencia uma sociedade cooperativa de produção agropecuária da sociedade empresária é a condição de sociedade de pessoas e a prestação de serviços para os cooperados, que confere àquela organização a característica de uma sociedade auxiliar 


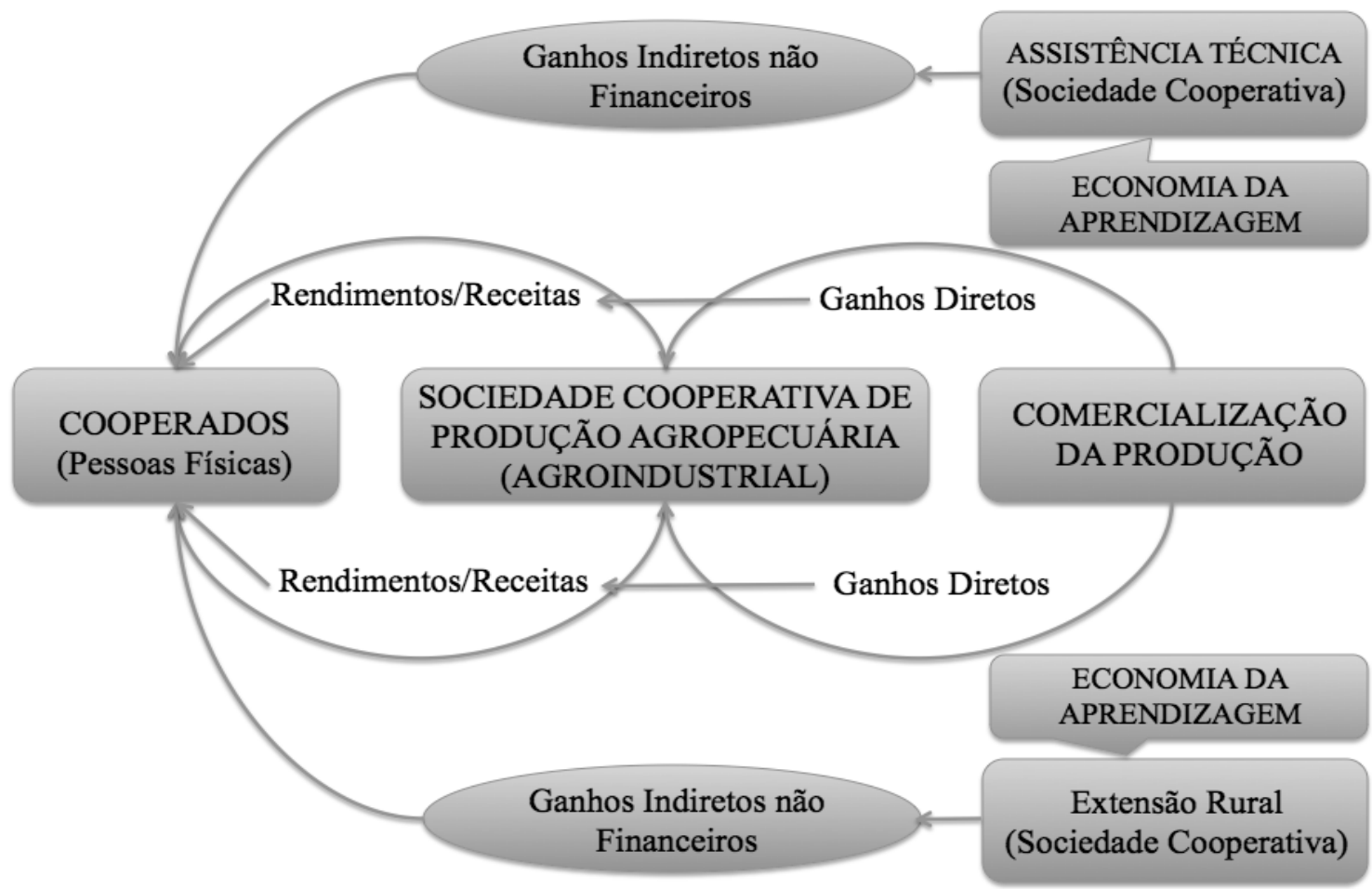

(cooperativas de produtores e cooperativas de produção agropecuárias, inclusive, as agroindustriais). Tal proposição se justifica pela intenção de as pessoas físicas se reunirem para satisfazerem as necessidades socioeconômicas utilizando tanto o esforço próprio como a ajuda mútua. A Figura 1 permite visualizar graficamente as operações realizadas pela sociedade cooperativa de produção agropecuária facilitando a melhor compreensão das operações realizadas com ênfase nos ganhos indiretos dos cooperados.

Figura 1 - Ganhos indiretos dos cooperados Fonte: Autor

Verifica-se a importância das ideias sociais e educativas, quando explícitas no objeto das sociedades cooperativas de produção agropecuárias e agroindustriais, principalmente quando exercitadas de forma contínua, podendo preservar a eficiência econômica da organização. Assim, as ideias são instrumentos para que os objetivos essencialmente qualitativos sejam alcançados, independentes das políticas estabelecidas pelos dirigentes da organização, que são direcionadas aos serviços prestados aos próprios cooperados. É nesse sentido, que se reconhece que o bem-estar material e social dos cooperados pode caminhar na mesma direção para atingir a finalidade desejável da organização cooperativa. A eficiência econômica da organização cooperativa pode ser demonstrada com efeitos positivos na economia por superar conflitos entre fatores de produção, a exemplo: o capital e o trabalho. 
O modelo societário cooperativo somente pode ser eficiente se a coordenação das atividades econômicas dos cooperados resultar em vantagens maiores que os custos da renúncia a uma condição de livre mercado. Eschenburg (1983) explica que a cooperação deve existir sobre parâmetros solidários somente em um primeiro instante na atividade da organização. Posteriormente, estabelece-se um processo em que o sucesso da cooperação somente ocorre se o benefício econômico que o cooperado encontra, em forma cooperativa, for necessariamente maior que o benefício econômico que o mesmo produtor rural poderia encontrar de forma autônoma, individual e livre no mercado.

O autor cita algumas características econômicas importantes do processo de cooperação, como a participação do cooperado nas atividades negociais. Nestas é identificado um custo de participação e cooperação para cada cooperado. Esse custo será o da perda da determinação econômica individual em favor do grupo de interesse do affectio societatis. Isso se expressa desde a necessidade de comercialização com regras comuns até o respeito às decisões majoritárias e igualitárias nas estruturas de governança e decisão, que, muitas vezes, são contrárias aos interesses particulares de determinado cooperado. Há uma característica de que ,o regime de cooperação induza o agente econômico a uma participação, e essa (participação) pode ser custosa do ponto de vista individual e econômico, ou seja, há um custo de oportunidade do tempo nesse processo de participação. Nessa linha argumentativa de Eschenburg (1983), os cooperados, produtores rurais pessoas físicas, somente participarão das organizações cooperativas se puderem usufruir dos benefícios econômicos e sociais e se estes forem superiores àqueles auferidos da exploração direta de suas atividades rurais.

Neste contexto, é que podem ocorrer situações de desvantagens econômicas nos casos de governança. Ou seja, a participação do cooperado pode ocorrer em situação inversa aos custos de oportunidades. Quanto maiores esses custos, menor será a participação do cooperado na sociedade cooperativa, isto é, toda vez que houver custo de oportunidade significativo do fator de produção para o cooperado produtor rural pessoa física, por motivo lógico ele não participará da organização cooperativa.

Abstraindo as situações particulares em que há desvantagens econômicas, a sociedade cooperativa pode permitir o crescimento individual do cooperado por meio da união de interesses pela atuação econômica peculiar, vez que nas sociedades cooperativas não se busca 
o objetivo de lucro ou de proveito próprio da instituição, mas, sim, como leciona Franke (1973), almeja-se a promoção da defesa ou fomento da economia dos cooperados mediante a prestação de serviços. E, ainda, por essa perspectiva, não dá para olvidar que o cooperado é o sujeito beneficiado do ganho econômico e financeiro. O ganho direto, que é representado pelo aumento de rendimentos e receitas ou redução de custos e despesas, ocorre com o aumento de produção e o consequente aumento da comercialização de produtos agropecuários; e o ganho indireto na melhoria econômica identificada pelo desenvolvimento de várias atividades realizadas pela sociedade cooperativa de produção agropecuária, como assistência técnica e profissional, extensão rural, aquelas decorrentes de serviços prestados em benefício comum dos cooperados, ou seja, sempre com o foco em negócios agropecuários desenvolvidos por essa organização societária.

A partir desse construto, o problema identificado é saber o seguinte: Diante da existência de ganhos socioeconômicos indiretos de caráter não financeiros, como são percebidos pelos cooperados pessoas físicas, produtores rurais, esses benefícios econômicos e não econômicos decorrentes das transferências realizadas pela sociedade cooperativa de produção agropecuária?

\subsection{OBJETIVOS}

\subsubsection{Objetivo geral}

O objetivo geral é mapear as percepções dos cooperados produtores rurais em relação aos ganhos socioeconômicos indiretos, de caráter não financeiro, decorrentes dos serviços prestados, em maioria de forma gratuita, pelas sociedades cooperativas de produção agropecuárias, inclusive, as agroindustriais.

\subsubsection{Objetivos específicos}

Especificamente, pretende-se: 
a) analisar a cooperação pela linha teórica da Nova Economia Institucional (NEI);

b) estudar a sociedade cooperativa de produção agropecuária pelo enfoque da teoria da firma, sem desconsiderar as relações econômicas e sociais com os cooperados;

c) analisar a composição do patrimônio líquido da sociedade cooperativa como fonte de recursos (rendas), para atender às transferências indiretas aos cooperados;

d) estudar os fatores determinantes da competitividade das sociedades cooperativas;

e) analisar o mapeamento das percepções econômicas e não econômicas dos cooperados nas relações existentes com a sociedade cooperativa de produção agropecuária; e,

f) pela ótica da teoria da renda, identificar os benefícios econômicos e sociais do cooperado produtor rural pessoa física dentro da sociedade cooperativa de produção agropecuária.

\subsection{ESTRUTURA DA TESE}

O presente conteúdo está organizado em sete capítulos, tendo como capítulo inicial a apresentação da pesquisa - problemática central, objetivos, justificativas e sua estrutura formal - concluindo o estudo com a lista de obras que embasaram o referencial teórico. Optou-se por estruturar os demais capítulos, uma vez que constituem, na essência, o estudo teórico, que será alinhado com a análise empírica, cujos problemas de pesquisas estão em consonância com os objetivos específicos da tese e com a questão geral de pesquisa.

No segundo capítulo, busca-se a análise da formação da cooperação, pela linha teórica da Nova Economia Institucional (NEI); o estudo do ambiente institucional, que estabelece o regramento das atividades desenvolvidas pela sociedade cooperativa de produção agropecuária; a dimensão do direito de propriedade dessa organização societária; a sociedade cooperativa de produção agropecuária na teoria econômica; e a sociedade cooperativa de produção agropecuária na concepção da teoria das firmas e suas peculiaridades.

O terceiro capítulo discute o patrimônio líquido das sociedades cooperativas de produção agropecuárias e agroindustriais e a capacidade da organização em gerar resultados econômico-financeiros positivos. 
O quarto capítulo versa sobre o cooperado, pessoa física, e teoria da renda; faz o mapeamento das percepções econômicas e não econômicas dos cooperados, das relações existentes com a sociedade cooperativa de produção agropecuária. Pela ótica da teoria da renda, analisam-se os benefícios econômicos e sociais do cooperado produtor rural pessoa física, na sociedade cooperativa de produção agropecuária, incluindo os aspectos metodológicos, para análise e desenvolvimento do estudo.

O quinto capítulo descreve a metodologia, com critérios objetivos para as entrevistas e questionários aplicados.

O sexto capítulo contém a análise e Discussão dos Resultados.

O sétimo capítulo traz as Considerações Finais. 


\section{A COOPERAÇÃO E SUAS PARTICULARIDADES}

A base teórica tem por finalidade fornecer o conhecimento acumulado até o momento para elaboração do suporte técnico, assim como permitir a melhor compreensão da lógica construtiva da pesquisa. Olson (1999) sustenta que o ponto lógico para iniciar qualquer estudo sistemático sobre as organizações é seu propósito. A sociedade cooperativa, de cunho econômico e social, tem como propósito a promoção dos interesses do cooperado pessoa física. Ou seja, a organização possui como finalidade a busca da conciliação dos benefícios sociais e a eficiência econômica por meio do trabalho, produção e ajuda mútua (cooperação). Nesse sentido, passa a ser relevante no contexto o estudo da cooperação econômica como meio de disseminação dos benefícios indivisíveis e generalizados das organizações em geral.

\subsection{A COOPERAÇÃO}

Segundo Pinheiro e Saddi (2005), o instituto da cooperação baseia-se na certeza firme e suficiente para a ação. Mas não é ação humana de todo rigorosa ou inflexível, porque repousa somente sobre certas probabilidades (inerentes à negociação), ou sobre uma mistura de sentimentos e/ou emoções fortes. Exemplifica-se: um ato cooperativo exige ação prática dos membros, mas não se sabe se um outro deseja igual ação; daí o conceito de probabilidade (ação e reação) de certas proposições, as quais, obviamente, podem estar influenciadas por fatores tais como a desconfiança. Assim, a cooperação implica também ponderar propostas divergentes e aceitá-las. Por outro lado, a cooperação pode ser entendida como a convergência de interesses, a integração de esforços em favor da geração de oportunidades na organização e da melhor aplicação dos fatores de produção, facilitando as relações contratuais entre as partes envolvidas, a sociedade cooperativa e os cooperados.

Para esses autores, a cooperação é um conjunto de transformações que objetivam produzir um acordo, um resultado que seja satisfatório para todos; é semelhante a uma característica de ação em que os elementos se transformam em convergência de interesses. Há identificação na similaridade dessa forma de cooperação nas relações negociais contratuais que se estabelecem entre os cooperados pessoas físicas, para almejar os objetivos definidos pela sociedade cooperativa de produção agropecuária. 
$\mathrm{Na}$ ótica econômica, Menard (2005) aponta que a cooperação é tratada como uma voluntariedade entre os agentes econômicos para unir os próprios recursos, quando existir benefícios para todos os envolvidos, a partir da união. Diante dessa constatação, surgem duas importantes correntes teóricas da economia a fim de explicar o surgimento da cooperação. A primeira é a microeconomia neoclássica, que estuda o comportamento do consumidor e assume que este tem racionalidade na escolha. $\mathrm{O}$ consumidor irá sempre querer maximizar o nível de satisfação representado por uma função utilidade. ${ }^{2}$ Assim, quando se considera o ato de cooperar como um bem, o consumidor irá optar em cooperar se, e somente se, este bem lhe trouxer maior nível de utilidade quando comparado com outro bem - a não cooperação.

Eschenburg (1983) por sua vez, afirma que na formação da cooperação o indivíduo toma uma decisão só quando a cooperação possibilita maior satisfação de necessidades, comparando sempre a cooperação com outras possibilidades de ação, que seria a não cooperação.

A segunda linha teórica para explicar a cooperação é apontada como a Nova Economia Institucional (NEI), sobretudo a economia dos custos de transação por meio do trabalho, de Williamson (1993), a partir das proposituras de Coase (1937). ${ }^{3}$

Ao tratar da cooperação, Williamson (1993) esclarece que ela pode surgir para gerar algumas vantagens para os envolvidos, como economia de escala na aquisição da informação e aumento da produtividade. Segundo o autor, da união desses agentes pode resultar no surgimento de diferentes arranjos contratuais como, por exemplo, alianças estratégicas e organizações cooperativas.

Partindo dessas premissas, é possível afirmar que a cooperação surge como estratégia

\footnotetext{
${ }^{2} \mathrm{Na}$ linguagem microeconômica, o conceito de utilidade se refere ao valor numérico que representa a satisfação que o consumidor obtém de uma cesta de mercado. Em outras palavras, a utilidade é um recurso usado para simplificar a classificação da cesta de mercado. Se a compra de três exemplares deste livro o deixa mais feliz do que a compra de uma camiseta, então dizemos que os livros têm mais utilidade para você que a camisa. A função utilidade é uma fórmula que atribui um nível de utilidades a cada cesta de mercado, (PINDYCK; RUBINFELD, 2010, p.9).

${ }^{3}$ Com a publicação do paper intitulado "The nature of the firm", a teoria econômica tratava com detalhes apenas os custos de produção. Embora fosse reconhecida a existência, também, da teoria da Nova Economia Institucional, a qual centraliza o conceito de custos de transação. Estes são os custos que os agentes que atuam no mercado incorrem em pesquisar, em coletar informações, bem como custos de barganha, de tomada de decisão, custos em impor uma disciplina nos contratos e custos de punição de desvios dos acordos contratuais (enforcement). Assim, as várias dimensões do conceito podem ser isoladas na identificação de custos mais específicos como os custos de informação, de negociação, de coordenação, de monitoramento e custos de enforcement (COASE, 1937).
} 
empresarial de coordenação de comportamentos, implicando conjugação de esforços e meios da organização envolvida no processo produtivo. Busca-se entender a cooperação por meio do estabelecimento de formas flexíveis de colaboração mútua, porém, limitada ao objeto social e ao tempo e à prossecução de certos objetivos comuns.

A cooperação pode ocorrer por intermédio da empresa, que é uma instituição que contrata fatores de produção e os organiza para produzir e vender bens e serviços. Para organizar a produção, as empresas coordenam as decisões e atividades econômicas de muitos indivíduos, sempre com o propósito de realizar as tarefas com mais eficiência do que os mercados. Essa ideia, de que as empresas existem porque há atividades nas quais elas são mais eficientes do que o mercado, foi sugerida por Coase (1937, p. 16), que se concentrou na capacidade de redução ou eliminação dos custos de transações.

No modelo cooperativo, o instituto da cooperação assume a forma estatutária particular. A organização, com lógica contratual específica, desempenha funções no processo produtivo, como o proveito comum, que poderá beneficiar a todos os cooperados, de forma direta ou indireta. A sociedade cooperativa agropecuária pode trazer economia em termos de custos de transações, beneficiar-se de economias de escala e economias de escopo e organizar a produção eficiente em equipe. Isso significa dizer que a organização tem a necessidade de descobrir com quem pretende negociar a produção dos cooperados, como conduzir as negociações em direção às atividades negociais, como redigir contratos, com observação das regras do jogo e, ainda, empreender as inspeções necessárias, a fim de garantir que os termos do contrato estejam sendo cumpridos.

Por sua vez, se o proveito é comum a todos os integrantes que decidiram pela cooperação, é evidente que o resultado econômico dos fatores de produção, poderá ou deverá ser distribuído entre todos. Diferente do que ocorre numa sociedade empresarial, onde o benefício alcança aqueles que mais empregaram capital social na organização. É nesse sentido que as sobras líquidas auferidas pela sociedade cooperativa se conjugam com a teoria da cooperação, pois nesta forma de organização societária, há como preservar a divisão da riqueza gerada entre os cooperados, o que não se vislumbra nas sociedades empresariais, porque se concentram no quantum do capital social dos sócios ou dos acionistas.

As sociedades cooperativas de produção agropecuária e agroindustrial, ao desempenhar 
atividades econômicas, nas operações decorrentes de atos não cooperativos, podem, sim, apurar o lucro, não se configurando em sociedade empresarial, cuja destinação obrigatória é o financiamento das atividades com os cooperados, sob o manto do Fundo de Assistência Técnica, Educacional e Social, mais conhecido por FATES (BRASIL, 1971).

A forma de cooperação pode ser identificada com o modelo de ação coletiva, defendida por Olson (1999). Tal forma afasta, portanto, toda e qualquer concepção econômica de mercado, em que as decisões sobre produção e consumo são feitas por produtores e consumidores. Neste caso, a cooperação se estrutura, basicamente, na lógica inversa: a da competição entre pessoas para o proveito dessa relação em favor de alguns.

Na cooperação, Williamson (1985) enfatiza que o nível de especialização dos ativos envolvidos no processo de produção, é determinante para o processo coordenativo de atividades, no qual, necessariamente, o conceito do instituto está diretamente envolvido por meio de relações contratuais entre os agentes econômicos. Dessa maneira, a cooperação não está diretamente relacionada à doutrina cooperativista, mas às relações contratuais entre os agentes econômicos, envolvidos nas atividades negociais de uma organização societária.

Na perspectiva de Bialoskorski Neto (2012), a cooperação deve ser vista como uma forma eficiente de coordenação, inclusive, substituindo a própria coordenação de mercado. $\mathrm{O}$ mesmo autor leciona que essa forma cooperativa só é vantajosa, se a coordenação das atividades econômicas dos agentes resultar em vantagens maiores que os custos da renúncia a uma condição de livre mercado. É nesse ambiente que a cooperação pauta a análise realizada em continuação.

Ações coletivas ou conjuntas, cooperação e colaboração são terminologias usualmente empregadas para referir o comportamento conjunto entre agentes e firmas. Esses agentes trabalham, geralmente, dentro de uma organização de maneira formal ou informal. A literatura científica discorre sobre vários conceitos de ação coletiva, evidentemente indispensáveis para a visualização da atividade cooperativa.

Mas Sandler (1995), esclarece que a ação coletiva é uma atividade que requer a coordenação de esforços de mais de um indivíduo, sem relevar a existência da forte interdependência entre os agentes envolvidos. E, na análise de Brito (2001), percebe-se que as ações coletivas 
existem em um grupo de agentes ligados entre si por diferentes motivos, e que podem ser de ordem financeira, tecnológica, cultural, entre outras. A partir desses significados construídos por estes autores acima citados, fica evidente que as razões justificativas da formação de ações coletivas, não são necessariamente financeiras, mas podem ser sociais, políticas e culturais.

Assim, ganha relevância no estudo da matéria a posição defendida por Harsanyi (1969), ao assegurar que o comportamento dos indivíduos pode ser explicado de dois interesses dominantes: o ganho econômico e a aceitação social. Tais interesses são percebidos na relação estabelecida entre as sociedades cooperativas de produção agropecuárias e agroindustriais, bem como entre cooperados, pessoas físicas e produtores rurais, para a consecução dos objetivos definidos estatutariamente.

Observa-se, também, que as ações coletivas podem ser representadas por variadas formas de associativismo que vão, desde a criação de entidades de representação política e sindical, até ações de compras mercadológicas e de serviços comuns, realizados pela sociedade cooperativa mista de produção agropecuária e a consequente prospecção e comercialização de seus produtos, decorrentes dos mercados interno e externo, entre outras opções. As empresas de pequeno porte, então, enfrentam muitas dificuldades que podem ser facilmente superadas por meio de iniciativas coletivas (SACHS, 2003). Essas dificuldades apontadas e as soluções encontradas podem ser estendidas também à sociedade cooperativa para obter seu pleno funcionamento.

Uma das obras mais citadas sobre ações coletivas é The logic of collective action, de Mancur Olson (1965). Sem dúvida, sua teoria veio contribuir para uma maior compreensão e um melhor ensinamento da lógica das ações coletivas, principalmente as relacionadas ao tema analisado. Esclarece especialmente aquilo que se refere à racionalidade dos indivíduos, em que é investigada a racionalidade individual versus a racionalidade coletiva. Para esse autor, os benefícios coletivos são insuficientes para motivar a contribuição individual, sendo que, na maioria dos casos, os agentes coletivos tendem a não comportar-se racionalmente para atingir os objetivos comuns do grupo (OLSON, 1999).

O autor também analisa a influência do tamanho do grupo para o comportamento coletivo, concluindo que os grupos menores são mais eficientes que os maiores: "Os grupos com mais 
membros geralmente desempenharão com menos eficiência do que os grupos com menos membros" (OLSON, 1999, p. 15). Depois, ao concluir, assevera que, quanto maior for o grupo, menos ele promoverá os interesses comuns, o que permite afirmar que o número de cooperados na sociedade cooperativa é uma variável importante, uma vez que o crescimento da organização implica, quase sempre, o aumento do número de membros, o que pode ser prejudicial à participação social de cada cooperado, particularmente por ocasionar o aumento de custo da própria governança.

É nesse sentido que a teoria econômica neoclássica contribui para a lógica das ações coletivas, ao concluir que há limites para a eficiência econômica das organizações. Se uma organização se tornar grande ou diversificada demais nas atividades que procura fazer, o custo de administração e monitoramento por unidade produzida, começa a subir. Então, em algum ponto, o mercado passa a ser mais eficiente na coordenação dos recursos (PARKIN, 2009).

Bialoskorski Neto (2012) acrescenta que os custos de governança cooperativa decorrem, provavelmente, dentre outros fatores, do fato de que, quanto maior a área geográfica de atuação, maior o número de cooperados, sendo mais difícil para a sociedade cooperativa de produção agropecuária incentivar a participação nas atividades da organização. E, ainda, também é mais difícil para o cooperado participar das assembleias e decisões, até mesmo pelos custos individuais de deslocamento, além de outros gastos de oportunidade inerentes às atividades desenvolvidas em benefício dos cooperados.

Vê-se, pois, importante avaliação deste autor quando constata que, no caso de sociedade cooperativa com maior número de cooperados, há também a probabilidade de ocorrer menor monitoramento entre os agentes; e, nesse caso, menor participação pode criar também menor compromisso relacional entre a sociedade cooperativa e os cooperados. De forma conclusiva, Bialoskorski Neto (2012) revela que, dada a relevância do número dos cooperados para a intensidade das participações na organização cooperativa, não só em função da maior divisão de poder na decisão, como também em função da dispersão geográfica do quadro social, isso pode tornar o custo de oportunidade da participação mais oneroso para o cooperado.

No mesmo sentido, observa-se, na teoria de Olson (1999), a preocupação com a eficiência. Explica o autor que os pequenos grupos são mais eficientes do que os grandes em função de três fatores principais: 
a) quanto menor o grupo, maior é a percepção que os atores têm do benefício alcançado pelo trabalho de cada agente;

b) o aproveitador (definido a seguir) fica mais evidente nos grupos menores;

c) quanto menor o grupo, menores os custos envolvidos para organizar a ação coletiva.

Convém assinalar que a abordagem feita por Olson (1999) sobre o tamanho dos grupos não leva em consideração a característica da heterogeneidade dos componentes da organização.

Por sua vez, Nassar e Zylbersztajn (2004), ao realizar apontamentos ao trabalho de Olson, adicionaram o fator heterogeneidade para explicar a eficiência dos grupos. Para esses autores, o importante são as constatações de que os grupos heterogêneos apresentam custos de transação mais altos do que os homogêneos, o que representa grande problema para o desempenho da ação coletiva. Na formação dos grupos, identifica-se a presença de aproveitadores, principalmente, ao constatar que, em grandes grupos, os agentes tendem a tolerar a presença de aproveitadores mais facilmente do que em pequenos grupos.

Na mesma linha, Brito (2001) contribui com o argumento de que o indivíduo aproveitador representa o oposto da cooperação, uma vez que não se preocupa em contribuir para os objetivos comuns, apresentando grande anomalia no sistema cooperativo. Essa contribuição fortalece o entendimento de Cook (1995a), quando define sociedade cooperativa como organização, com uma arquitetura contratual, que apresenta direitos de propriedade vagamente definidos, com problemas do free-rider (carona), em que os benefícios da entidade acabam por albergar também membros não cooperativados, que não se relacionam em termos de atividades e custos com a organização, mas que se utilizam dos resultados econômicos por práticas irregulares, ao arrepio da própria legislação de regência.

Deve-se destacar que as contribuições de Ostrom (2007), não são desprezíveis. Para essa autora, o foco principal da teoria da ação coletiva está no entender a razão dos indivíduos em cooperar num dilema social, quando podem aproveitar-se (pegar carona) da ajuda de outros membros do grupo. A autora assevera também que é extremamente desafiador investigar a ação coletiva, porque é importante reconhecer no instituto a relação complexa entre as variáveis que influenciam os sistemas coletivos. Ela classifica em três elementos o nível de 
influência sobre a cooperação entre os indivíduos e, consequentemente, o resultado das ações coletivas: a reputação, a confiança e a reciprocidade. Aduz, ainda, que o processo é muito complexo, pois a reputação, a confiança e a reciprocidade também são influenciadas por outras variáveis estruturais, quais sejam:
a) o número de participantes envolvidos;
b) a forma de divisão dos recursos (divididos ou totalmente partilhados);
c) a heterogeneidade dos participantes;
d) a comunicação face a face;
e) a existência de aproveitadores;
f) a existência de informações sobre ações passadas;
g) a ligação dos indivíduos; e
h) a liberdade para entrar e sair.

O nível de reputação, confiança e reciprocidade dos indivíduos envoltos num sistema coletivo é de grande interesse para a consistência da ação coletiva. Para Ostrom (2007), a diminuição da influência de qualquer uma das três variáveis centrais pode gerar declínio na ação coletiva levando a pouca ou nenhuma cooperação.

De maneira geral, verifica-se que a posição defendida por Ostrom (2007) está em consonância com a visão de Olson (1999) sobre a dificuldade de os indivíduos trabalharem para o bemestar coletivo em detrimento do bem-estar individual. Para Ostrom (2007), mesmo que os atores possuam interesses comuns, há forças contrárias a uma atuação coletiva, pois os agentes imaginam que o esforço que irão despender será maior do que o benefício da ação conjunta.

Essas contribuições fortalecem a argumentação da teoria da lógica das ações coletivas, que prega que dificilmente os indivíduos procuram como resultado o bem-estar coletivo, contrastando com o bem-estar individual. Assim, mesmo compartilhando interesses comuns, os agentes tendem a não atuar de forma coletiva, pois acreditam que o esforço despendido de forma individual será maior do que o benefício que poderão obter com a ação coletiva (OLSON, 1999, p. 15). Esse problema apresenta-se como de grande relevância e, para superar a não participação, são necessários mecanismos de incentivo para os agentes, que poderão ser 
criados com várias finalidades, seja de fundo socioeconômico, seja psicológico, como, por exemplo, prestígio, respeito e amizade.

Para Olson (1999), esses incentivos são classificados em duas espécies: positivos, que são os benefícios privados oferecidos para os agentes coletivos; e negativos, que são punições para os indivíduos que não contribuem com as ações coletivas. Ambos servem como motivação para a contribuição individual na ação coletiva.

Gintis et alii (2005) também contribuem para a teoria de ações coletivas. Nos seus ensinamentos, os autores apresentam uma visão diferente de cooperação, divergindo da tese dos sociólogos e dos economistas. Contrariamente, os autores argumentam que significativa parcela de indivíduos são cooperativos e punidores altruístas, ou seja, pensam mais nos outros quando se trata no benefício da cooperação.

Merece ressaltar também a posição defendida por Sachs (2003), para quem é possível testemunhar sinergias extremamente benéficas entre os empreendimentos que são o resultado entre cooperação e concorrência. $\mathrm{O}$ fato de os empreendedores de um mesmo ramo competirem entre si, não exclui iniciativa e ações compartilhadas voltadas à solução de problemas comuns.

De maneira geral, pode-se afirmar que, por meio de relacionamentos coletivos, os agentes conseguem obter os recursos de que não dispõem com maior facilidade, uma vez que praticamente nenhuma organização pode ser considerada autossuficiente. Isso, consequentemente, pode reduzir os custos de transação, conforme Farina et alii (1997).

A linha teórica ora analisada destacou os elementos importantes existentes dentro de um sistema coletivo como interdependência entre agentes, oportunidades de ganhos coletivos e riscos da cooperação. Entretanto, não há como olvidar que, no relacionamento coletivo, os agentes podem atingir os objetivos com maior facilidade e eficiência, utilizando-se da cooperação latente, expressa na forma de sociedade cooperativa de produção agropecuária.

Portanto, pela conjugação da declaração de vontades e dos relacionamentos coletivos dos cooperados a favor de uma atividade econômica, flui como alternativa o modelo cooperativo (cooperação) como ação resultante em proveito comum e sem fins lucrativos. A sociedade 
cooperativa de produção agropecuária surge da expressa união de pessoas físicas, que se obrigam à cooperação, mediante a prestação de serviços aos cooperados, cujo resultado pode motivar a geração de renda a ser distribuída de forma igualitária e de acordo com a participação de cada um.

\subsection{O AMBIENTE INSTITUCIONAL}

Para North (1990), as instituições são importantes a fim de diminuir a incerteza e estabelecer uma base estável às relações contratuais. Elas podem oferecer oportunidades para a sociedade em geral, e as organizações são criadas visando a tirar proveito dessas oportunidades geradas pelo ambiente institucional. ${ }^{4}$

O principal papel das instituições ${ }^{5}$ numa sociedade - entendidas como as "regras do jogo", formais e informais, que estruturam a interação social, econômica e política - é restringir a ação humana (NORTH, 1991). Essas regras são também desenvolvidas com o objetivo de reduzir incertezas no mercado e, portanto, os custos de transação. Os institutos estabelecem incentivos e padrões das transações contratuais entre as intraorganizações. Segundo o autor, o papel das instituições está em organizar o ambiente de negócio, reduzir as incertezas e, em conjunto com outros instrumentos econômicos, definir um conjunto possível de escolhas, criando um ambiente favorável para o processo de tomada de decisão. Assim, as instituições fornecem uma estrutura de incentivos, contribuindo para o desempenho da economia, podendo influenciar a forma como a organização surge, se comporta e afeta os modelos de governança corporativa e desempenho (NORTH, 1990; WILLIAMSON, 1996, p. 16).

Entende-se como instituições formais, por exemplo, o conjunto de leis, decretos, instruções legais, impostas por um governo ou agente com poder de coerção. Já as informais seriam

\footnotetext{
${ }^{4} \mathrm{O}$ ambiente institucional é baseado em regras políticas, sociais e legais fundamentais que estabelecem a base para a produção, a troca e a distribuição. Regras que administram eleições, direito de propriedade e o direito de contrato são exemplos (...) $\mathrm{O}$ arranjo institucional é um arranjo entre unidades econômicas que administram o meio pelo qual tais unidade podem cooperar (...) ou podem fornecer um mecanismo capaz de proporcionar uma mudança nas leis ou no direito de propriedade (WILLIAMSON, 1996, p. 103)

${ }^{5}$ Instituições são as regras do jogo, tanto as formais quanto as informais e também as suas características de eficácia. Juntas, definem a forma em que o jogo deve ser jogado. As organizações são os jogadores. Elas são compostas de grupos de indivíduos que possuem o mesmo objetivo comum. Organizações econômicas são firmas, sindicatos, cooperativas etc.; organizações políticas são os partidos políticos, legislativo, órgãos regulatórios; organizações educacionais são universidades, escolas, centro de treinamento vocacional (NORTH, 1991, p. 84).
} 
estatutos, códigos de conduta, normas e costumes formados pela própria sociedade. Portanto, o ambiente institucional formal e informal impõe restrições às formas de governança das sociedades cooperativas brasileiras, sendo o principal o regramento específico trazido pela Lei $\mathrm{n}^{\mathrm{o}} 5.764$ (BRASIL, 1971) e, posteriormente, o direito de empresa no Código Civil - Lei $\mathrm{n}^{\mathrm{o}}$ 10.406 (BRASIL, 2002).

A diferença entre o ambiente institucional e os arranjos institucionais traz aspectos atinentes de grande relevância para a análise da pesquisa. Observa-se que parte da literatura da teoria neoinstitucionalista foca o ambiente institucional, buscando entender sua influência sobre, de um lado, o desempenho econômico e, de outro, o comportamento dos agentes econômicos. O ambiente institucional é importante na caracterização das sociedades cooperativas de produção agropecuárias e agroindustriais, no que se refere ao desempenho econômico e social, assim como nas relações contratuais com o cooperado e os fornecedores, entre outros. Por outro lado, o arranjo institucional é aquele que se estabelece entre as unidades econômicas que administram o meio pelo qual tais unidades podem cooperar, ou podem fornecer um mecanismo e proporcionar mudança nas leis ou no direito de propriedade.

Cook (1995b) define cinco estágios entre o aparecimento, o crescimento e a extinção dessa forma de organização por meio de uma leitura institucional. Em relação ao aparecimento da organização, os agentes econômicos buscam uma atitude de defesa contra o sistema de preços e mercados falhos. Tal fato pode ser caracterizado pelo oportunismo empresarial, quando as sociedades empresariais elevam os preços dos insumos ou reduzem os preços das commodities agrícolas, fazendo com que seja sustentável uma atitude diversa da defesa, aliada às facilidades institucionais de políticas públicas que visam à elevação da renda da atividade rural.

$\mathrm{O}$ autor conclui que, desde que as sociedades cooperativas sobrevivam aos mercados concentrados, no estágio seguinte seus preços e condutas não serão diferentes dos preços praticados pelas sociedades empresariais, mas apresentarão custos de transação mais elevados, dada a distribuição do direito de propriedade, quando haveria desvantagem competitiva. Nos últimos estágios, a sociedade cooperativa deve adaptar-se a uma nova estrutura, que minimize os custos de transação e desvantagens diante das sociedades empresariais, estabelecendo alianças estratégicas com outras formas de organização 
societária, transformando-se em uma entidade que tenha direitos de propriedade mais bem estabelecidos, com sua transformação em sociedade anônima ou a extinção pela liquidação.

Pelo enfoque do ambiente institucional, é necessário compreender os fatores que levam à formação e à manutenção da sociedade cooperativa, assim como os direitos de propriedade, a divisão entre propriedade e controle, bem como estrutura de capital. Diante dessas regras, a formação e o estabelecimento de uma sociedade cooperativa originam situações em que há nítida escassez do principal fator de produção: o capital.

A estrutura de capital das sociedades cooperativas de produção agropecuária, inclusive, as sociedades agroindustriais, no Brasil obedecem à Lei no 5.764 (BRASIL, 1971), que, no artigo $1^{\circ}$, define as organizações cooperativas como sociedade civil de pessoas (sociedade simples) e não sociedade de capital (sociedade empresarial). Há uma composição do capital em quotas-partes, além da limitação do número de quotas-partes por cooperado, podendo esse valor ser proporcional, e ainda há a inacessibilidade das quotas-partes do capital a terceiros, estranhos à sociedade (KRUEGER, 2003). O Código Civil de 2002, no artigo 982, caracteriza as sociedades cooperativas como sociedades simples e também manteve a intransferibilidade das quotas-partes de capital a terceiros, estranhos à sociedade, mesmo que por herança ou processo sucessório.

Tradicionalmente, as quotas-partes de capital das sociedades cooperativas pertencem exclusivamente aos proprietários, cujo resgate pode não ser simultâneo ao desligamento do cooperado do quadro societário, e não necessariamente são remuneradas. Ademais, a distribuição do resultado dessas organizações (sobras líquidas) não considera a quantidade de quotas-partes dos cooperados. A forma utilizada é a transação econômica, caracterizada pela relação contratual entre a sociedade cooperativa e o proprietário, enquanto usuário ou cliente dos serviços da organização. Ou seja, quanto mais o cooperado utilizar os serviços da cooperativa, maior será sua participação nos resultados (CHADDAD; COOK, 2004; HANSMANN, 1988; STAATZ, 1987; VITALIANO, 1983).

Por sua vez, há obrigatoriedade de constituição de fundo de reserva destinado a reparar perdas; para o desenvolvimento das atividades com 10\%, pelo menos, das sobras líquidas do 
exercício; e para o Fates, ${ }^{6}$ destinado à prestação de assistência aos cooperados e familiares e, quando previsto nos estatutos, aos empregados da sociedade cooperativa, constituído de 5\%, pelo menos, também das sobras líquidas.

Portanto, a sociedade cooperativa de produção agropecuária financia, com recursos disponíveis no Fates, as operações decorrentes da prática de atos típicos entre a sociedade cooperativa e os cooperados que são comuns nesse tipo de organização societária. Por último, a sociedade cooperativa de produção agropecuária pode instituir, sempre por meio de Assembleia Geral, órgão máximo da sociedade, quaisquer outros tipos de fundo que sejam úteis para a organização, podendo ser permanente ou temporário. As especificações desses fundos dependem de cada cooperativa, devendo, na forma do estatuto, prever a formação, destino, aplicação e liquidação, inclusive, se divisível entre os cooperados, em caso de liquidação, na ausência de previsão, de modo a se distinguir dos fundos obrigatórios.

\subsection{A DIMENSÃO DO DIREITO DE PROPRIEDADE}

O direito de propriedade, em regra, é entendido como direito ou poder de consumir, obter rendimentos ou mesmo alienar um ativo da organização societária. Ou seja, o direito de propriedade sobre uma organização é aquele em que há possibilidade de usar os benefícios decorrentes da atividade operacional e obter, ao final do processo produtivo, a apropriação devida sobre o resíduo ou resultado positivo. Inclui-se aí, também, a transação desse direito no mercado, convertendo o ativo produtivo em unidades monetárias.

Esse direito, na concepção econômica desenvolvida por Alchian (1965; 1987) e Cheung (1969), é essencialmente a capacidade de desfrutar de um pedaço de propriedade. Ambos os autores enfatizam que o direito de propriedade não se limita à dimensão legal, pois, além dela, inclui-se a questão das normas sociais, ou seja, as forças dos costumes sociais e do desejo de integração, porque também condicionam o uso dos recursos e, portanto, circunscrevem os direitos de propriedade.

\footnotetext{
${ }^{6}$ O Fundo de Assistência Técnica, Educacional e Social (Fates) é um recurso de grande valia para os cooperados, familiares e empregados, tudo para manter os princípios cooperativistas da educação, do equilíbrio social e da possibilidade de oportunidades; entretanto, o emprego desse fundo deve estar previsto no estatuto social (LIMA, 1997).
} 
Fulton (1995) ensina que os direitos de propriedade - definidos como o poder de obter renda, consumir ou alienar determinado ativo em uma cooperativa - não estão separados do controle da organização, em que os cooperados não podem apropriar-se do direito em forma de lucro residual. $\mathrm{O}$ autor afirma que a teoria do direito de propriedade pode ocupar o papel central na teoria institucional. Nas sociedades cooperativas, os cooperados são aqueles que detêm os direitos residuais ao fluxo de rendimentos gerados pela organização. Mas, como os direitos de propriedade sobre esse ativo são divididos e não há separação completa, os cooperados não podem apossar-se dos fluxos oriundos desses direitos de forma igualitária. Ao complementar aduz que, quando há um direito comum de propriedade entre muitas pessoas, este é confundido diretamente com recursos de livre acesso. Essa situação leva a outra, em que o direito de propriedade seja exercido por um grupo de pessoas com obrigações de gestão, de acordo com regras formais - estatutos - e informais - éticas -; e, assim, os recursos acabam por não ser totalmente explorados.

Comparativamente, pode-se afirmar o seguinte: nas sociedades cooperativas há uma noção de direito comum de propriedade, enquanto nas sociedades empresariais, esse direito é individual, com fronteira claramente definida, sendo o proprietário do capital aquele sócio ou acionista que tem direitos residuais aos rendimentos auferidos da organização na forma de pró-labore e de lucros distribuídos. Trata-se de um diferencial importante, tanto que os direitos de propriedade de uma sociedade empresária anônima podem ser negociados em mercados de capitais e são transferidos entre as partes, o que efetivamente não acontece em relação às sociedades cooperativas, implicando custos de transação diferentes para essas duas formas de organizações societárias.

A alocação inicial dos direitos de propriedade nas sociedades cooperativas de produção agropecuárias e agroindustriais é primariamente estabelecida pelo ambiente institucional formal externo - Lei $\mathrm{n}^{\circ} 5.764$ (BRASIL, 1971). Isto é, esse instituto regula, entre outros itens, desde o número mínimo de proprietários, as formas de execução do controle e o estabelecimento da quota-parte do capital social de cada cooperado.

Por outro lado, os serviços prestados pelas sociedades cooperativas agropecuárias aos cooperados são, em maioria, gratuitos, condição que valoriza as relações de usuário, mas não cria um julgamento de valor quanto ao recebimento de serviços pelos cooperados. Assim, a 
dimensão do usuário pode ser caracterizada como um contrato relacional. O desenho dos contratos certamente responde às motivações econômicas, assim como às dificuldades de transformar o acordo sobre o padrão de comportamento em ações de interesse comum. No entanto, as possibilidades de configuração de um contrato dependem, também, da história do relacionamento entre as partes e do conjunto de atividades e transações que cada sociedade cooperativa mantém, por ocasião da celebração do contrato, com o cooperado.

A visão relacional dos contratos, segundo SPEIDEL, 1993 apud ZYLBERSZTAJN, 2005destaca três pontos com importantes implicações à contratação:

a) a transação se prolonga no tempo;

b) elementos de troca não podem ser mensurados ou especificados precisamente (por ocasião da celebração do contrato);

c) a interdependência das partes com relação à troca transcende, em alguns momentos, uma única transação, passando a um conjunto de inter-relações sociais.

Como consequência, em situações de dependência econômica, o contrato ultrapassa a mera transferência de direitos de propriedade e passa a representar um complexo de transações, em que os deveres não são todos explicitamente considerados, mas estão implícitos na relação econômica de interesse mútuo das partes.

Nesse contexto, quando participa de uma sociedade cooperativa agropecuária mediante uma relação estatutária, o cooperado cria, com o tempo, um compromisso confiável em torno da continuidade dessa relação, uma vez que, ao assim proceder, as partes interagem com objetivo comum, criando uma motivação de dependência econômica, nas várias operações de transferências de ganhos diretos e indiretos.

A dependência econômica pode ser considerada uma problemática, porque as partes (cooperados e sociedade cooperativa de produção agropecuária) não são capazes de prever todas as possíveis contingências e incorporar as respectivas salvaguardas, na ocasião da formalização do estatuto social. Os contratos são incompletos, apresentando lacunas que abrem possibilidade de ocorrência de custos derivados da dependência econômica, haja vista não ser possível formatar um contrato completo, devendo as partes criar mecanismos para solucionar as contingências inesperadas. 
A orientação para o desempenho econômico não é oposta à doutrina cooperativista, mas, pelo contrário, é uma condição para que a sociedade cooperativa possa cumprir sua missão: prestar serviços aos associados e melhor remunerar a produção, uma vez que o sucesso da cooperação somente ocorre quando o benefício econômico auferido pelo cooperado é superior ao que obteria de forma individual e livre no mercado. Assim, os resultados econômicos das atividades organizadas pelas firmas dependem tanto das regras internas das firmas, quanto da estrutura externa dos direitos de propriedade. E essa forma é realizada por meio do estatuto social.

Identifica-se, na relação estatutária do cooperado e a sociedade cooperativa de produção agropecuária, a apropriação do direito econômico da propriedade, manifestado pela melhoria puramente econômica do cooperado, que se mescla às aspirações sociais. Esta é pontuada pela expansão de várias atividades desenvolvidas pela organização, como a assistência técnica e extensão rural, pelos serviços prestados por meio de incorporação de programas operacionais e inovações tecnológicas projetados em benefícios comuns dos cooperados e pela assistência profissional e assemelhadas, como a realização de cursos, palestras, treinamentos e eventos em geral, entre outros.

Nessa relação, os cooperados são capazes de absorver e processar, de forma razoável, as informações disponibilizadas, podendo-se deduzir que a busca pela maximização da utilidade está sujeita às restrições cognitivas, que podem transformar a capacidade de processamento mental no fato mais importante a ser economizado, (WILLIAMSON, 2012, p.18).

Não há como negar que o comportamento do cooperado deve ser baseado na busca do interesse próprio, com respeito à regra do jogo. Pela ótica da Teoria do Custo de Transação, o comportamento humano é marcado pelo oportunismo, definido como uma maneira mais forte de buscar o interesse próprio, que pode incluir práticas irregulares, levando as pessoas a esconder ou distorcer informações, respeitando as regras do jogo, se lhe convier. Entretanto, o cooperado deve praticar os atos negociais sempre sob a égide dos bons costumes, preservando o interesse coletivo à luz das regras institucionais.

Diante das características apontadas, na sociedade cooperativa de produção agropecuária, há possibilidade de usar os benefícios decorrentes da atividade operacional e obter, ao final do 
processo produtivo, a apropriação devida sobre o resíduo ou resultado positivo. Quando esses benefícios forem em forma de melhoria de preços, condições de produção e assistência técnica, podem resultar em maior indefinição de direitos sobre a propriedade e sobre a própria decisão de utilização.

Ressalta-se que essas organizações são regidas pelo princípio da mutualidade, pois suas decisões não obedecem à força do capital investido dos cooperados, mas subjetivamente ao valor da pessoa física ou pessoa jurídica que as compõem, pouco importando o quantum de sua contribuição material (bens fungíveis ou infungíveis) nas atividades negociais. $O$ princípio da mutualidade requer a conjugação partidária de esforços entre os cooperados para, por meio da organização e graças a ela, obter resultados comuns, eliminando intermediários na circulação de riqueza. Entre os cooperados haverá, portanto, uma comunidade unitária de capital e de interesses. Os cooperados devem participar das decisões sobre o funcionamento da sociedade cooperativa de produção agropecuária; e, havendo decisão da assembleia, parte das sobras líquidas podem ser destinadas para constituir o Fates, e o restante ser distribuído.

\subsection{SOCIEDADE COOPERATIVA DE PRODUÇÃO AGROPECUÁRIA}

\subsubsection{A firma e suas particularidades}

Inicialmente, esta tese apresentou a ótica do cooperado, de sua utilidade e da maximização das sobras líquidas como direito de propriedade residual. No entanto, equilibradamente, procura-se evidenciar que a grandeza desses fatores econômicos vai depender substancialmente da evolução da firma cooperativa, de modo inter-relacionado. É, portanto, fundamental a visão do comportamento da firma e das particularidades, para melhor compreender o cooperativismo como atividade-meio para o desenvolvimento econômico e social dos cooperados.

Do ponto de vista neoclássico, vários são os autores que conceituam a firma como uma unidade técnica, onde se produzem mercadorias e serviços, de acordo com uma função de produção, em que diversos fatores são alocados entre diferentes usos e proporções, determinados sempre pelo mecanismo de preços. Ou seja, enquanto para a Economia 
Neoclássica a firma é uma função de produção, a Economia dos Custos de Transação entende que é uma empresa de governança alternativa em relação ao mercado (WILLIAMSON, 1996).

Contudo, para Bialoskorski Neto (2012), a firma é entendida como um arranjo de diferentes contratos entre diversos agentes econômicos, em que o custo de transação afetaria não só esses arranjos, mas também a alocação de recursos e a forma com que os bens e serviços são produzidos. Há, pois, custos de transação que devem ser considerados e são diferentes da simples incerteza nas negociações, ou mesmo dos custos de informação. Williamson (1985) define esses custos de transação como os custos ex-ante de elaborar um instrumento contratual e os custos ex-post dessa negociação.

Num dos aspectos mais importantes dos estudos do economista americano, Coase (1937, p. 16), refere-se às firmas e como estas atuam, ou seja, por meios de contratos (firma contratual), notando que "as organizações são relações contratuais coordenadas por mecanismos idealizados pelos agentes produtivos"(SZTAJN et alii apud SZTAJN; ZYLBERSZTAJN,2005, p. 105).

Nesse modo de entender, tudo o que se relacione a contratos passa a ser importante para a economia, como os adimplementos e as formas de solução de controvérsias, ou mesmo, pela criação da personalidade jurídica com funcionamento das organizações societárias e com a criação de empresa para alocação de recursos da produção, por meio de decisão hierárquica.

Para Coase (1937), a firma é vista como um arranjo institucional que substitui a contratação renovada de fatores no mercado, por uma outra forma de contratação, representada por um vínculo duradouro entre fatores de produção. Dessa forma, o emprego do capital e do trabalho, por exemplo, a exploração da atividade rural pelo cooperado, a industrialização e a comercialização de sua produção, sem a interferência da organização cooperativa, alcançariam resultado diferente. Esse resultado decorre de vários fatores, principalmente da garantia da estabilidade na manutenção do preço e da qualidade do produto, ao longo de um futuro indeterminado, incluindo as variações de mercado que podem vir a ocorrer. Portanto, no arranjo institucional, há a estabilidade e a garantia nas relações econômicas, que são os meios indispensáveis para o cooperado alcançar o resultado desejável, decorrente da exploração, industrialização e comercialização da produção rural. 
$\mathrm{Na}$ abordagem realizada por Coase (1937), identificam-se duas alternativas de alocação de recursos na firma: uma pelo mercado, flexível, elástica, respondendo à mudança nas condições e sinalizada pelos preços; outra, pela hierarquia, correspondendo às ordens emitidas pela hierarquia interna da firma, que destina os fatores contratados na utilização produtiva. Essas alternativas são percebidas também nas sociedades cooperativas de produção agropecuária, inclusive, as de produção agroindustrial; porém, ante suas peculiaridades, os recursos dessas firmas são obtidos, em grande parte, pelos aportes de capital, realizados pelos cooperados e decorrentes das destinações específicas da sociedade cooperativa, as sobras líquidas ou os lucros apurados nas operações atípicas.

Na mesma linha argumentativa, Alchian e Demsetz (1972) visualizam a empresa como um meio de realizar as economias de produção da equipe, sendo que os membros dessa equipe estão vinculados à empresa por um nexo de contratos. De acordo com estes autores, a vida da firma é explicada pela necessidade de manter uma equipe e controlar seu desenvolvimento. A firma é alcançada quando a produção de um ativo e de alguns fatores forem utilizados, conjuntamente, ficando difícil de saber o que decorre da contribuição do próprio indivíduo, em termos de trabalho (e, portanto, todos poderiam ser incentivados a trabalhar menos), requerendo uma pessoa para ser responsável apenas para controlar os outros. O controlador será pago a partir do excedente gerado, em virtude do controle que realiza: com melhor controle, há maior retorno do residual. Para Coase (1937) e Williamson (1983), além da observação de Guido (2011), existe a necessidade para a empresa-eficiência de operar com redução dos custos de monitoramento em vez de custos de transação.

Ante a inequívoca existência das empresas no mundo real, cumpre identificar o fundamento da existência das firmas. Para Alchian e Demsetz (1972), esse fundamento, relacionado à cooperação nas relações econômicas, residiria na necessidade de organizar a produção em equipe (team productive process) mediante a polarização de todas as reações contratuais em um único sujeito (centralized contractual agent), que é a empresa. A produção em equipe é conceituada como três tipos de produção:

Produção 1) diversos tipos de recursos são utilizados e 2) o produto não é a soma de separáveis resultados (outputs) de cada recurso cooperativo. Um fator adicional cria um problema de organização de equipe; - 3) nem todos os recursos utilizados na produção em equipe pertencem a uma pessoa. (ALCHIAN; DEMSETZ, 1972, p 23) 
Nesse sentido, a firma será mais eficiente à medida que remunerar aqueles que cooperarem, na proporção do esforço de cada um. Para tanto, contribuem dois conceitos fundamentais da firma: a medição da produtividade e a remuneração proporcional ao esforço (ALCHIAN; DEMSETZ, 1972, p 33).

A medição da produtividade e a recompensa conduzida pelo mercado não são isentas de custos, pois envolvem custos de medição. Por esse motivo, haverá ocasiões em que o mercado desempenhará deficientemente essas funções, em especial quando se trata da medição dos esforços realizados por diversos sujeitos para uma atividade comum e a correlata recompensa. Nesses casos, pode haver mais eficiência na organização em equipe, isto é, na forma de empresa, que cuidará de medir a produtividade marginal de cada um dos agentes econômicos que cooperam com a produção, de modo a recompensá-los na média de sua contribuição. Com efeito, Achian e Demsetz (1972) entreveem, na firma, um mecanismo de viabializar a team production, nos casos em que o esforço de cada indivíduo é necessário para a produção, mas não se consegue distinguir, no out put, no sentido de quanto o indivíduo colaborou.

Assim, a produção em equipe (isto é, em empresa) torna-se mais eficiente, precisamente nos casos em que há dificuldade na medição da produtividade marginal de cada um dos agentes que aportam recursos com uma finalidade comum, de modo a determinar a remuneração correspondente.

Olson (1999, p. 15) contribui para a compreensão da firma quando enfatiza que não há sentido em formar uma organização, quando uma ação individual independente pode servir aos interesses do indivíduo tão bem ou melhor do que aquela (firma). Assim, as organizações podem desempenhar uma função importante, quando há interesses comuns ou grupais a serem defendidos; embora elas, frequentemente, também sirvam a interesses puramente pessoais e individuais, com funções e características básicas de promover interesses comuns de grupos de indivíduos.

Por sua vez, utilizando os conceitos de cooperação e analisando as vertentes teóricas do estudo das organizações cooperativas apresentadas por Cook et alii (1995b), as sociedades cooperativas podem ser visualizadas como uma firma, que é extensão de propriedade do 
cooperado. A firma constitui o nexo de contratos entre os cooperados produtores rurais que decidiram cooperar.

Para Sztajn et alii (apud SZTAJN; ZYLBERSZTAJN, 2005, p. 32), o contrato tem como motivação econômica o interesse mútuo das partes, o qual precisa modificar-se numa transferência de direitos e estabelecimento de deveres. E, ainda, é necessário repisar que as organizações cooperativas são criadas para promover os interesses comuns dos cooperados, com direitos igualitários de ter serviços, informações e assistência técnica.

Staatz (1987) define a sociedade cooperativa agropecuária como uma organização econômica de propriedade coletiva, constituída por produtores rurais, com o intuito de fazer frente às falhas de mercado. A propriedade das cooperativas é concretizada desde que o cooperado estabeleça contrato formal com a organização e assuma a obrigatoriedade de adquirir cotaspartes de capital (capital social) da sociedade para ter direitos garantidos de propriedade e de usuário. Como não há clara separação desses distintos direitos no contrato, os cooperados adquirem direitos vagamente definidos. Essa característica dificulta a gestão e o investimento nas organizações. Em síntese, as cooperativas diferem das demais organizações (sociedades empresariais) por duas razões: os cooperados são simultaneamente proprietários, usuários e consumidores dos produtos e serviços e o direito ao controle não é vinculado ao direito residual (COOK, 1995, p. 21).

Os cooperados, por imposição institucional externa e com vista a otimizar o processo de tomada de decisão, reúnem-se em assembleias gerais para exercer o direito de controle residual. Por exemplo, nas assembleias, elegem o conselho administrativo e, por meio de instrumentos contratuais legais, transferem-lhe o direito de controle formal. Portanto, cabe à autoridade formal controlar a organização.

Diferentemente do modelo de Rochdale, outro tipo de sociedade cooperativa, que Olson (1995) apropriadamente denomina de Kirkpatrick, é controlado exclusivamente por uma organização legal e independente, com objetivos mais legislativos e lobísticos do que comerciais ou econômicos. Via de regra, a sociedade cooperativa Kirkpatrick tem sido bastante lucrativa, lucratividade que deriva, frequentemente, do tratamento tributário favorável. Ressalte-se que o modelo societário em análise tem, como suporte fático do 
ambiente institucional, a Lei $\mathrm{n}^{\mathrm{o}} 5.764$ (BRASIL, 1971), possuindo tratamento tributário adequado, já previsto constitucionalmente.

Observa-se que as instituições são relevantes na análise econômica e podem ser

compreendidas e explicadas por meio de instrumental dessa teoria. É nesse sentido que a firma é considerada uma rede de contratos entre os proprietários dos recursos utilizados no processo produtivo e a sociedade cooperativa de produção agropecuária. Esta centraliza as relações contratuais de natureza socioeconômica, utiliza-se de modelo societário específico, definido com a finalidade precípua de prestação de serviços aos cooperados.

Para a investigação teórica da firma, a análise aqui conduzida será centrada em nível de instituições formais e mecanismos de governança, seguindo sempre a escola liderada por Williamson (1996): as organizações influenciam as instituições e são por elas influenciadas.

É nesse contexto, sob regras formalmente definidas, que os cooperados podem obter ganhos pecuniários e não pecuniários. Os ganhos não pecuniários são relacionados ao status, ao conforto e aos gastos supérfluos, descritos por vários autores como privilégios. Tais ganhos não são destinados ao aumento de riqueza, mas sim ao aumento do bem-estar dos cooperados.

\subsubsection{O tamanho da firma}

Em regra, a grande firma, ao dominar amplos segmentos do mercado em que atua, usufrui de oportunidades tecnológicas diferenciadas em relação aos concorrentes de menor porte. A sociedade cooperativa só existirá em condições de especificidade de ativos - bens, serviços e recursos humanos, na teoria do custo de transação - quando existir cooperação entre os agentes econômicos, como única coalizão possível de maior retorno, para fazer frente a uma situação de nítida escassez de capital, por exemplo. Por essa ótica, a cooperação existirá para possibilitar ganhos econômico-financeiros aos produtores rurais, cooperados em mercados concentrados.

A firma forma-se e cresce em um ambiente institucional no qual é necessário o aporte de capital. Dadas as restrições institucionais, devido à legislação societária e aos aspectos doutrinários do cooperativismo, esse aporte em regra é efetuado de duas formas: a primeira, 
por meio da capitalização, via subscrição de quotas-partes dos cooperados; e a segunda, por meio da obtenção de empréstimos financeiros. Outrossim, poderá haver aporte de capital por meio da venda de bens imobiliários da sociedade cooperativa e, não menos comum, o decorrente lucro obtido como resultado de atos não cooperativos. Semelhantes formas de capitalização serão desenvolvidas com a continuação desse estudo científico.

Hendrikse (1993) descreve que, em decorrência de algumas características da estrutura dos direitos de propriedade e dos ativos específicos na firma, é possível haver algumas formas diferentes de governança. Mas para Bialoskorski Neto (1998), a estrutura de capital da firma implica uma particular ordenação do controle. Numa firma de capital aberto - sociedade empresária -, o controle é efetuado pelos sócios ou acionistas de modo proporcional ao número de cotas ou ações respectivamente - capital investido - e, neste caso, endividamento da empresa -, por meio de financiamento com o capital de terceiros; é uma situação intermediária, uma vez que a capitalização de longo prazo é efetuada, frequentemente, por meio da abertura do capital social.

$\mathrm{Na}$ sociedade cooperativa não é possível abertura de estrutura de direitos de decisão e propriedade ao público externo à organização. Os aportes capitais de qualquer natureza contêm maior expectativa de risco, expressa por meio de taxas de juros. ${ }^{7}$ Quando o estudo em questão é uma firma sociedade cooperativa, devido aos preceitos doutrinários de a cada homem, um único voto e de inacessibilidade das quotas-partes, não é possível abrir o capital social com diferente estrutura de direitos de propriedade e decisão (BIALOSKORSKI NETO, 1996).

Entretanto, devido ao crescimento da sociedade cooperativa e à especificidade dos ativos, esta forma organizacional tem maior nível de custos de governança financeira quando comparada ao de outras formas organizacionais, ou seja, apresenta-se menos eficiente do ponto de vista econômico e financeiro. Alia-se a essa análise o fato de que, quanto maior for a sociedade cooperativa, possivelmente haverá grande proporção de capital de terceiros na estrutura de capital e mais instável poderá ser a estrutura de controle e decisão, acarretando maior nível de risco para os agentes financeiros.

\footnotetext{
${ }^{7}$ Os agentes financeiros procuram ser compensados com maiores prêmios, quando há alocação difusa do direito de decisão e de propriedade, e quando há incerteza quanto à estrutura de gestão, formada, nas cooperativas, por cooperados, muitas vezes sem formação profissional e com mandato dependente das assembleias da organização.
} 
De acordo com Hendrikse (1993), conforme cresce a especificidade de ativos, o custo de governança financeira das sociedades cooperativas tende a ser maior que aqueles das empresas não cooperativas, chamadas de firmas de capital. A representação gráfica, na Figura 2, permite que se observe essa relação direta entre as duas variáveis.

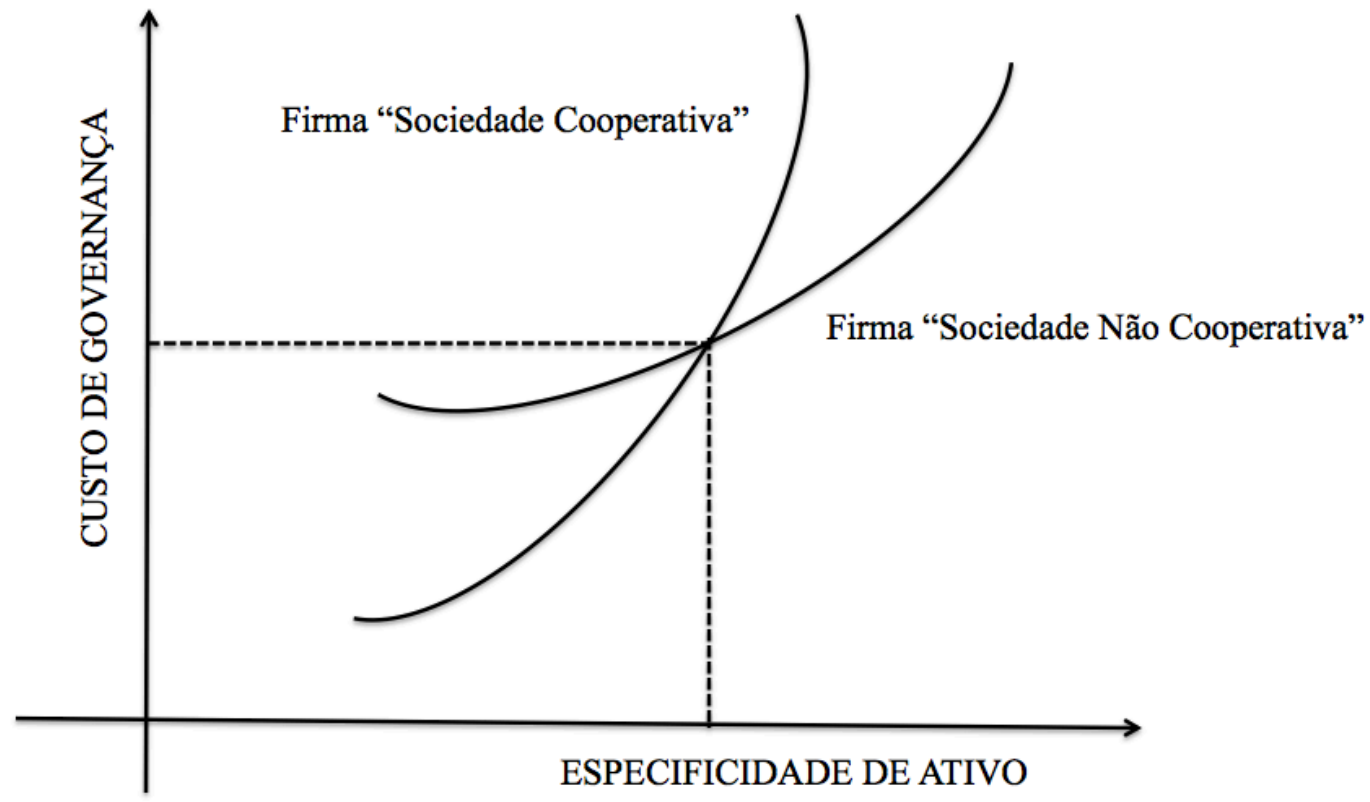

Figura 2 - Ganhos indiretos cooperados

Fonte: Adaptado de HENDRIKSE (1993, p.36)

Assim, há limitação institucional à abertura de capital das firmas sociedades cooperativas, fazendo com que em nível de governança financeira para essas firmas haja restrição nítida às formas de gestão e otimização de resultados. Nascimento (2000, p. 10) enfatiza que a sociedade cooperativa não deve expandir-se de forma isolada, ampliando tentáculos e distorcendo objetivos. O crescimento autossustentado das sociedades cooperativas como tal só poderá ocorrer de forma sistêmica. A existência de sociedades cooperativas que se integram em diversos níveis, horizontal e verticalmente, e que retoma a ideia das pequenas ou grandes sociedades cooperativas singulares, de natureza comunitária, deve pressupor o objetivo de atendimento do cooperado e ser constituídas no tamanho exato das demandas do grupo de membros.

Portanto, as sociedades cooperativas crescem quando se integram a outras sociedades cooperativas de graus diferentes, criando-se sistemas, estes sim, de tamanho ilimitado, com 
aumento de custos de governança financeira, mas proporcionais quando comparados ao de firmas não cooperativas (sociedades empresariais).

\subsection{COMPETITIVIDADE DAS SOCIEDADES COOPERATIVAS}

O ensaio de Cechin (2014) acentua que, em algumas cooperativas do Norte da Europa, adotase o modelo de governança empresarial. Os cooperados delegam a autoridade formal e real para o Conselho Administrativo, mas retêm os direitos de controle ex post da decisão no Conselho Fiscal. No modelo empresarial, apenas participam do Conselho Administrativo profissionais de fora, ou seja, não cooperados à cooperativa, responsáveis pela função de gestão da decisão.

No Sul da Europa, os modelos de governança cooperativa dominantes são o tradicional e o tradicional estendido (BIJMAN et alii, 2013; CHADDAD; ILIOPOULOS, 2013). O modelo tradicional de governança é adotado pela grande maioria das pequenas cooperativas agropecuárias, localizadas em todos os países mediterrânicos da União Europeia (UE).

Embora não haja estudos sistemáticos sobre o tema, o arcabouço jurídico brasileiro não permite às sociedades cooperativas com estruturas híbridas em direitos de propriedade, tampouco permite a entrada de não cooperados nos Conselhos de Administração das sociedades cooperativas e o voto do associado proporcional ao valor transacionado com a cooperativa ou à sua quota-parte. Em relação à separação entre propriedade e decisão de gestão, Cechin (2014) esclarece que a maioria das sociedades cooperativas agropecuárias brasileiras, hoje concentra ambas as funções. Também por isso, o processo de “desmutualização" não tem ocorrido no Brasil. Para o autor, como a gestão nas cooperativas é efetuada no Brasil diretamente pelos produtores cooperados, tal estratégia não é exequível. Há evidências, no entanto, de que diferentes modelos de governança coexistem no País, pois há um grupo que já adota modelos de governança que promovem a separação parcial entre propriedade e decisão de gestão. 
A estratégia de produção de muitas cooperativas das Regiões Sul e Sudeste, a partir da década de 1970, passou a ser a busca pela integração vertical (à jusante) por meio da industrialização, de modo a agregar valor aos produtos e evitar a intermediação comercial, (CECHIN, 2014). Dessa forma, observa-se que o desempenho do ramo cooperativo no Estado do Rio Grande do Sul vem sendo condicionado por mudanças nos planos tecnológicos e de organização do mercado das sociedades cooperativas. Em regra geral, elas procuram seguir a mesma trajetória das sociedades empresariais no setor de agronegócios.

A estrutura das sociedades cooperativas é complexa, criada para prestar serviço aos cooperados, pessoas físicas, produtores rurais, utilizando-se das relações contratuais coordenadas por mecanismos idealizados pelos agentes produtivos. E, ainda, insere-se no mercado competitivo com taxa de crescimento determinado, principalmente, pelo aumento da população e da renda do consumidor. Entretanto, o aumento da concorrência e diminuição do resultado apurado anualmente, tem motivado que essas organizações pratiquem outras formas de competição.

Sob a pressão da concorrência dos setores relacionados com a produção, a industrialização e a comercialização do arroz, da soja, da uva, verifica-se a ocorrência de modernização dos processos de produção, adotando-se, inclusive, terceirização de alguma etapa de produção e de prestação de serviços, como forma de redução de custos e despesas dessas organizações.

As transformações ocorridas nessas sociedades cooperativas e as inovações introduzidas no processo produtivo e organizacional refletiram-se na mudança da utilização das estratégias competitivas, que eram antes baseadas na simples oferta de produtos agropecuários recebidos dos cooperados e mão de obra sem especialização e de baixo custo. E agora, voltam-se para outras estratégias, baseadas no desenvolvimento de novos produtos e novas formas de organização e de processo produtivo.

Para concorrer com as grandes empresas agroindustriais era, e ainda é, imprescindível a capitalização e o investimento em modernização e expansão. O problema dessa estratégia, no entanto, está na dificuldade que as sociedades cooperativas têm de se financiar, e nas divergências de interesses de seus cooperados, que vão crescendo com o aumento dos associados. Assim, passou a ser necessária a busca por eficiência e a utilização das sobras 
líquidas das receitas da sociedade cooperativa para reinvestimento. Só assim, as cooperativas agropecuárias brasileiras se manteriam economicamente saudáveis (CECHIN, 2014).

Com o propósito de contribuir com as principais mudanças ocorridas na estrutura e na organização dos diversos ramos das sociedades cooperativas em estudo e, assim, identificar o estágio competitivo existente, uma vez que os determinantes das vantagens competitivas dos setores foram modificados, torna-se necessário apresentar os aspectos competitivos presentes, fazendo um elo entre os desempenhos desses segmentos cooperativos e os padrões de concorrência vigentes.

\subsubsection{Fundamentos da competitividade}

A definição de competitividade segue a linha de pensamento de Ferraz et alii (1995), os quais definem o instituto como "a capacidade da empresa formular e implementar estratégias concorrenciais, que lhe permitam ampliar ou conservar, de forma duradoura, uma posição sustentável no mercado. Para Thompson et alii (2008),

a estratégia competitiva de uma empresa lida exclusivamente com os aspectos específicos para concorrer de modo bem-sucedido - as iniciativas específicas para satisfazer os clientes, as ações ofensivas e defensivas para opor-se às manobras dos concorrentes, as respostas a todas as condições de mercado dos concorrentes no momento, as iniciativas para consolidar a posição de mercado e a abordagem para assegurar uma vantagem competitiva perante os concorrentes. $\mathrm{Na}$ maioria das empresas, o alvo é, simplesmente, realizar um trabalho significativamente melhor do que os concorrentes para oferecer aquilo que os compradores desejam e, portanto, garantir uma vantagem no mercado.

Uma empresa obtém vantagem competitiva sempre que possui algum tipo de vantagem na atração de clientes e no enfretamento das forças competitivas. Há muitos caminhos para se alcançar vantagem competitiva, porém todos envolvem oferecer aos compradores aquilo que eles percebem como valor superior em comparação à oferta dos vendedores concorrentes. $\mathrm{O}$ valor superior pode significar um bom produto a um preço menor; um produto superior pelo qual vale a pena pagar um preço maior ou uma oferta de excelente valor que represente uma combinação atrativa de preço, características, qualidade, serviço e outros atributos atrativos. Proporcionar valor superior - seja qual for a forma - exige quase sempre desempenhar atividades na cadeia de valor de modo diferente daquele dos concorrentes e obter competências que não são prontamente igualadas. THOMPSON et alii (2008, p. 133). 
Conforme Porter (1989), a competitividade consiste na capacidade sustentável de uma empresa em criar um desempenho superior no mercado. As empresas devem escolher um caminho diferente daquele tomado pelas outras empresas, ou seja, em vez de competir para ser a melhor, as empresas devem competir para serem únicas (MAGRETTA, 2012). A essência da vantagem competitiva está no caráter único do valor que se cria e de como ele é criado.

A vantagem competitiva surge do valor que uma empresa consegue criar para seus compradores, devendo ultrapassar o custo de fabricação da empresa, para que o negócio seja rentável. Para Porter (1989):

\footnotetext{
O valor é aquilo que os compradores estão dispostos a pagar, e o valor superior provém da oferta de preços mais baixos dos que os da concorrência por benefícios equivalentes ou do fornecimento de benefícios singulares que mais do que compensam um preço mais alto (PORTER, 1989, p. 2).
}

Essas diferenças de custo e preço entre as empresas concorrentes originam-se das mais variadas atividades de valor que as empresas exercem enquanto competem. As atividades de valor podem ser classificadas em primárias e de apoio. As atividades primárias - compostas por logística interna, operações, logística externa, marketing e vendas, serviços - são atividades envolvidas na criação física do produto, na sua venda e transferência para o comprador, bem como na assistência após a venda. As atividades de apoio - aquisições de bens e serviços, gerência de recursos humanos, desenvolvimento da tecnologia, infraestrutura da empresa - sustentam a estrutura e os insumos imprescindíveis para a realização das atividades primárias (PORTER, 1989).

Ainda de acordo com Porter (1989), para o alcance da vantagem competitiva, há três tipos de estratégias: liderança no custo, diferenciação e enfoque. A liderança no custo dá-se quando a empresa torna-se o produtor de baixo custo, através da descoberta e exploração intensiva das fontes que impliquem vantagens de custo (por exemplo, baixo custo da mão de obra, matériaprima abundante, entre outros), visando ao interesse do público com demanda sensível ao preço. Normalmente, apresenta escopo amplo e atende a muitos segmentos, predominando a economia de escala. Em regra, os produtores vendem produtos homogêneos-padrão, sem maquilagem, dando ênfase à obtenção de vantagens de custo absoluto e de escala de todas as fontes (PORTER, 1989). 
Essa dinâmica de definições mostra, de forma abrangente, o processo de concorrência como referencial para avaliação da competitividade, ou seja, esta não está associada tão somente a uma característica intrínseca de um produto ou de uma firma, mas aparece também como uma característica extrínseca relacionada com o padrão de concorrência imanente ao mercado específico e aos elementos que o determinam.

Muitas cooperativas têm imitado empresas privadas na modernização da gestão, tornando-a operacional. Uma gestão mais operacional permite que as cooperativas definam e apliquem, efetivamente, as normas de qualidade para o fornecimento, controlem a qualidade dos produtos, monitorem os processos produtivos dos associados e, no limite, excluam daquela atividade específica, associados que não atendem às exigências da cooperativa (BIJMAN, 2009; HANF, 2009).

Com a finalidade de monitorar a fidelidade e reduzir o risco de oportunismo dos cooperados, emergiram no Brasil relações contratuais entre sociedade cooperativa e produtor associado, CECHIN (2014). Para o autor, o associado é livre para entregar sua produção e adquirir insumos pela cooperativa, isto é, não há obrigatoriedade de transações. A consequência disso é que, se as cooperativas investem em instalações para armazenar e/ou processar as commodities, e os cooperados não cumprem as promessas de fornecimento, a eficiência da organização é seriamente comprometida. Os arranjos que surgiram para evitar tal ineficiência são expressos, por exemplo, em cláusulas de exclusividade na entrega, ou seja, de fidelidade. Embora presentes com frequência nos estatutos das cooperativas, raramente tais cláusulas são executadas (SERIGATI; AZEVEDO, 2013).

Contextualizado a temática da competitividade, é importante saber se as sociedades cooperativas em análise adotam estratégias competitivas (gastos em aumento de eficiência produtiva, qualidade, inovação, propaganda, entre outras), com a finalidade de obter ou alcançar um certo nível de capacidade que favoreça a concorrência em preço, esforço de venda ou diferenciação de produtos, de acordo com o padrão de concorrência vigente no seu mercado específico. Ou seja, a competitividade depende de criação e renovação das vantagens competitivas por parte dessas organizações, em processo no qual cada produtor busca obter particularidades que o distingam favoravelmente dos demais, em termos de custo e/ou preço, qualidade, ritmo de inovação, habilidade de servir os próprios cooperados. 
Portanto, é possível afirmar que a competitividade é função da adequação das estratégias das sociedades cooperativas de produção agropecuária ao padrão de concorrência vigente no mercado específico, ou seja, tomando-se por base essa linha de pensamento, em que cada mercado vigoraria um dado padrão de concorrência, definido a partir da integração entre estrutura e condutas dominantes no setor, no qual seriam competitivas aquelas que, a cada instância, adotassem estratégias competitivas mais adequadas ao padrão de concorrência do mercado específico. 


\section{A SOCIEDADE COOPERATIVA DE PRODUÇÃO AGROPECUÁRIA E SUA CAPACIDADE DE GERAR RENDAS}

\subsection{PATRIMÔNIO LÍQUIDO DAS SOCIEDADES COOPERATIVAS}

\subsubsection{Patrimônio}

O patrimônio pode ser observado sob diversos aspectos, pois, para cada ciência, há uma forma especial de leitura, podendo ser objeto de questionamento da ciência econômica, da ciência

administrativa, do direito e da sociologia, entre outras. É sobre o aspecto do reconhecimento e registro na contabilidade que mais se articulam as análises administrativas e econômicas de diferentes significados do patrimônio da sociedade.

No tocante ao conceito jurídico de patrimônio, seja no sentido civil e comercial, seja no direito público, entende-se como o conjunto de bens, direitos e obrigações aplicável economicamente, isto é, em dinheiro, pertencente a uma pessoa, natural ou jurídica, e constituindo universalidade (DE PLÁCIDO E SILVA, 2003).

Do ponto de vista econômico, o patrimônio é observado de outra forma, ou seja, pelo prisma da ciência econômica, como riqueza ou bem susceptível de cumprir a necessidade de uma coletividade.

Diante dessas definições, pode-se afirmar que patrimônio é um conjunto de bens de uma pessoa física ou jurídica, sujeito a uma administração com a finalidade de auferir lucro ou criar renda. No caso específico de uma organização societária, o patrimônio é, em geral, formado pela diferença entre o ativo e o passivo. Quando essa diferença é positiva, fala-se em patrimônio líquido; em caso de ela ser negativa, chama-se passivo a descoberto ou passivo líquido (SANDRONI, 2005).

Por sua vez, patrimônio líquido é o complexo de valores econômicos de uma empresa, segundo o dicionarista Houaiss (2004). Ele corresponde ao valor residual dos ativos da entidade, depois de deduzidos todos os passivos. Apesar de o patrimônio líquido ser definido como valor residual, ele tem subclassificações no balanço patrimonial, como recursos 
aportados pelos sócios e acionistas. No caso de sociedades cooperativas de produção agropecuária e agroindustrial, os recursos são aportes dos cooperados e decorrentes das reservas resultantes de apropriações das sobras líquidas, lucros, entre outras.

Pela ótica contábil, o patrimônio líquido é representativo apenas da diferença entre o valor do ativo registrado e o valor do passivo reconhecido. O Comitê de Pronunciamento Contábil (CPC), ao tratar do conceitual básico - Estrutura Conceitual para Elaboração e Apresentação das Demonstrações Contábeis ${ }^{8}$ - conceitua ativo como um recurso controlado pela entidade, como resultado de eventos passados e do qual se espera que resultem futuros benefícios econômicos para a entidade. Esse benefício embutido em um ativo é o potencial no sentido de contribuir, direta ou indiretamente, com o fluxo de caixa para a entidade. Tal potencial poderá ser produtivo, quando o recurso for parte integrante das atividades operacionais da entidade.

Diante de tais definições, e considerando que o valor investido pela organização societária constitui o menor valor que se espera obter de retorno no futuro, o valor registrado no ativo representa uma posição conservadora a respeito do potencial de geração de benefícios futuros. Partindo desse ativo, subtraindo-se o passivo da entidade, representado pela obrigação derivada de eventos já ocorridos, cuja liquidação se espera que resulte em saída de recursos capazes de gerar benefícios econômicos, tem-se o patrimônio líquido - que representa o potencial de geração de benefícios futuros aos detentores dos direitos residuais, ou seja, o patrimônio que sobraria, após pagar todas as obrigações perante terceiros.

No caso das sociedades cooperativas de produção agropecuárias, inclusive as agroindustriais, os detentores desses direitos residuais são os próprios cooperados. O patrimônio líquido da organização pode revelar mais do que apenas o número da diferença entre ativo e passivo representativa de riqueza líquida. Trata-se de uma parcela do capital social investido pelos cooperados, ora definido como o recurso financeiro inicial necessário para implantação da capacidade produtiva; a outra, são as sobras líquidas, após a destinação legal, acumuladas ao longo do tempo, que podem ser capitalizadas ou distribuídas aos cooperados; e, ainda, o lucro

\footnotetext{
${ }^{8}$ Aprovado pela Resolução CFC no 1.121 , de 2008 - NBCT 1 - Estrutura Conceitual para a Elaboração e Apresentação das Demonstrações Contábeis e pela Deliberação CVM no 539, de 2008, ambas elaboradas com base no Framework for the Preparation and Presentation of Financial Statements do International Accounting Standards Board(IASB).
} 
líquido decorrente das operações com não cooperados, que tem destinação própria. Observase que o resultado (sobras líquidas ou lucro) depende, não só da estrutura externa dos direitos de propriedade, como também da estrutura de direitos de propriedade, do ponto de vista interno às sociedades cooperativas, direitos esses caracterizados pelas regras internas e pela estrutura organizacional.

Pela relevância da classificação no balanço patrimonial, destacam-se três grupos de contas contábeis no patrimônio líquido de uma sociedade cooperativa de produção agropecuária: capital social, reservas, sobras ou perdas líquidas. As sobras líquidas ficam à disposição da Assembleia Geral e, quando ocorrem, as perdas líquidas devem ser debitadas na conta corrente dos cooperados. O lucro ou prejuízo acumulado, decorrente das operações realizadas com os não cooperados, tem destinação própria, não podendo ser distribuídos. O Quadro 1 a seguir traz as principais contas específicas que integram o patrimônio líquido da sociedade cooperativa de produção agropecuária.

Quadro 1 - Principais contas de patrimônio líquido da sociedade cooperativa

\begin{tabular}{|l|}
\hline Capital social integralizado \\
\hline Capital Social Subscrito \\
(-) Capital Social a Integralizar \\
\hline Lucros ou prejuízos acumulados \\
$(-)$ Parcela Destinada para RATES \\
$(+)$ Parcela do Prejuízo Absorvida pela Reserva Legal \\
\hline Ajustes de avaliação patrimonial (BRASIL, 2007) \\
\hline Reserva de incentivos fiscais \\
Reserva de Doações para Investimentos \\
Reserva de Subvenções para Investimentos \\
\hline Sobras ou perdas líquidas \\
Reserva Legal \\
Fates \\
Fates Constituído \\
(-) Rates Aplicada \\
Assistência Técnica \\
Assistência Educacional \\
Assistência Social \\
\hline Saldo (sobras ou perdas líquidas) à disposição da Assembleia-Geral \\
\hline
\end{tabular}

Fonte: Autor

\subsubsection{Capital social}

O capital social cumpre funções diversas: formar o acervo material mínimo, inicial, para que a atividade possa ser estruturada e principiada; fixar a medida da participação do cooperado; mostrar a solidez da sociedade cooperativa e servir de garantia mínima aos credores. 
É dividido em quotas-partes, cujo valor unitário não pode ser superior ao maior salário mínimo vigente no país (BRASIL, 1971). Todavia, nenhum cooperado pode subscrever mais de um terço do total das quotas-partes, salvo nas sociedades cooperativas em que a subscrição deva ser diretamente proporcional aos movimentos financeiros do cooperado, ou ao quantitativo dos produtos a ser comercializados, beneficiados ou transformados, ou ainda, em relação à área cultivada, ou ao número de plantas e animais em exploração (BRASIL, 1971).

$\mathrm{Na}$ formação do capital social pode ser estipulado que o pagamento das quotas-partes seja realizado mediante prestações periódicas, independentemente de chamada, por meio de contribuições ou outra forma estabelecida a critério dos respectivos órgãos executivos federais (BRASIL, 1971).

Em relação à integralização das quotas-partes e ao aumento do capital social da sociedade cooperativa de produção agropecuária, ambos podem ser feitos com bens avaliados previamente. E após homologação da Assembleia Geral, mediante a retenção de determinada porcentagem do valor do movimento financeiro de cada cooperado (BRASIL, 1971).

O Código Civil - Livro II - Do Direito de Empresa prevê que o capital social será variável segundo o ingresso e a retirada dos cooperados, independentemente de qualquer formalidade homologatória. Isso significa dizer que bastará ao interessado, quando se tornar cooperado, apresentar-se, comprovar afinidade ao escopo da sociedade e comprometer-se a pagar o valor das quotas-partes que subscrever nas condições em que forem oferecidas. $\mathrm{Na}$ saída da sociedade, será suficiente que se apresente como retirante e receba o valor das quotas-partes, mais o que tiver direito, de acordo com as regras vigentes na organização. A regra prevê a possibilidade de dispensa de capital social, formado por quotas-partes dos cooperados, permitindo que a sociedade cooperativa possa iniciar as atividades sem o recurso inicial.

Sendo a sociedade cooperativa de produção agropecuária uma entidade sui generis ou especial, instituída em razão das pessoas dos cooperados, a atividade não visa ao lucro, mas ao bem-estar econômico e social dos participantes, vislumbrando-se nesse tipo de organização o vínculo de natureza pessoal e não patrimonial (BRASIL, 1971). 
No patrimônio líquido, o capital social pode ser segregado em duas contas: subscrito e a integralizar. A quantia que os cooperados se comprometem a investir na cooperativa é denominada de capital subscrito. Enquanto esses recursos não estão disponíveis de fato, eles são classificados na conta redutora de patrimônio líquido: o capital a integralizar. No momento da integralização propriamente dita, a conta capital a integralizar é diminuída pelo mesmo valor. Sendo assim, contabilmente o capital social pode ser visto como o capital integralizado, ou seja, a diferença entre o capital subscrito e o capital a integralizar.

Portanto, em relação ao capital social das sociedades cooperativas, a Resolução do Conselho Federal de Contabilidade (CFC) $n^{\circ}$ 920, de 2001, não é diferente da Lei $n^{\circ} 5.764$ (BRASIL, 1971), quando afirma que ele "é formado por quotas-partes, que devem ser registradas deforma individualizada por se tratar de sociedade de pessoas, segregando o capital subscrito e o capital a integralizar." Adicionalmente, "a conta do capital social discriminará o montante subscrito e, por dedução, a parcela ainda não realizada” (BRASIL, 1976).

\subsubsection{Demonstração do resultado do exercício}

Na linguagem comercial, o resultado positivo do exercício é o lucro, o provento ou o ganho obtido num negócio. É o que provém das operações mercantis ou das atividades comerciais realizadas pelas sociedades em geral. Por resultado, em sentido propriamente contábil, entende-se a conclusão a que se chega na verificação de uma conta ou no levantamento de um balanço: o mesmo que crédito, lucro ou prejuízo.

Em relação às contas, refere-se ao saldo da demonstração dos resultados do exercício, que tanto pode ser credor - lucro contábil - como devedor - prejuízo contábil (BRASIL, 1976).

A propósito do fechamento de balanços patrimoniais, alude-se à apuração dos lucros ou prejuízos em determinados períodos. Dessa forma, o resultado ou o que se apurou na escrituração comercial da pessoa jurídica, tanto pode ser favorável, quando há lucro contábil, como desfavorável, quando se verifica prejuízo contábil.

Di Diego (2011) ensina que a demonstração do resultado do exercício (DRE) é um documento contábil que visa ao processo de formação de resultado econômico alcançado pela pessoa 
jurídica, desde a receita bruta (faturamento) até o resultado líquido do período (lucro ou prejuízo contábil). Nessa demonstração, é que a sociedade cooperativa de produção agropecuária deverá descrever os dados que reflitam o desempenho positivo ou negativo da entidade no decorrer do último exercício, mediante a exposição dos resultados com as vendas ou serviços a terceiros ou aos próprios cooperados. Através de outros dados decorrentes de operações relativas ao ato não cooperativo, indica-se também as despesas provocadas pelas atividade operacional, tais como salários, encargos, tributos etc.

Para o autor português, o lucro periódico ou de balanço da sociedade tem como origem o que a citação seguinte declara:

\begin{abstract}
Daí que a lei venha permitir que, em determinados momentos - e o momento azado para o efeito é o da elaboração do balanço (donde decorre a designação que lhe é atribuída) - se determine o lucro, dito periódico ou de balanço, da sociedade.

Este lucro de balanço (que a doutrina alemã e italiana constuma designar respectivamente por totalgewinn e utile complessivo ou utile di bilancio) representa o acréscimo patrimonial gerado e acumulado pela sociedade desde o início da sua atividade até determinada data (a data a que se reporta a elaboração do balanço) e que é distribuível pelos sócios, correspondendo à diferença entre o patrimônio líquido da sociedade, por um lado, e a soma do capital e das reservas indisponíveis (reservas legais e estaturárias) por outro (DI DIEGO, 2011. p. 211).
\end{abstract}

Ao tratar do lucro do exercício, convém acrescentar o seguinte:

O lucro de exercício, ou o lucro obtido no exercício, consiste "na expressão monetária do resultado positivo da atividade desenvolvida pela empresa social durante o mesmo exercício". Ou seja, há lucro de exercício quando o valor do patrimônio líquido da sociedade é, no final do ano econômico e em resultado da sua atividade, superior ao que existia no início. I.é, trata-se do excedente patrimonial criado apenas durante esse ano - que no balanço consta da rubrica "Resultados do Exercício" da Situação Líquida - e que poderá traduzir-se na seguinte equação: Lex $=$ PSF - PSi, em que, Lex = Lucro de exercício; PSF = Patrimônio social líquido final do exercício; PSi $=$ Patrimônio social líquido no início do exercício (DOMINGUES et alii, 2007, p. 217-8).

Registre-se, ainda, que as normas do direito das sociedades portuguesas, que tratam da apuração do lucro do exercício, estabelecem que o escopo lucrativo é um dos elementos essenciais do conceito de sociedade. O fim da sociedade há de ser necessariamente a obtenção de lucro para distribuição aos sócios ou acionistas. Ou seja, tem-se como princípio que o lucro pode ser revestido de duas vertentes: o lucro objetivo, que consiste no incremento patrimonial, no enriquecimento do patrimônio da sociedade; e o lucro subjetivo, que se traduz no fato de aquele incremento patrimonial da sociedade ser ou poder ser distribuído aos sócios. 
No mesmo sentido, a regra de direito societário brasileiro prescreve a ordem de apresentação das receitas, custos e despesas na $\mathrm{DRE}^{9}$ para fins de publicação. Ressalte-se, ainda, que sempre os princípios contábeis devem nortear a contabilidade das sociedades cooperativas no reconhecimento contábil das receitas (ingressos), custos e despesas (dispêndios), porque, como as demais pessoas jurídicas, aquelas também são obrigadas a elaborar as demonstrações financeiras por expressa determinação legal (BRASIL, 1976).

As sociedades cooperativas de produção agropecuárias, inclusive, as agroindustriais, como entidades empresariais, igualmente estão sujeitas ao levantamento de balanços de exercício social. O exercício social representa o período de gestão dos negócios da sociedade, findo o qual, os dirigentes da sociedade cooperativa devem, obrigatoriamente, encerrar as contas da escrituração, realizar a elaboração das demonstrações financeiras e fazer o relatório dos atos da administração, a fim de submetê-lo ao julgamento da Assembleia Geral.

No tocante ao conteúdo e à forma de apresentação da demonstração financeira da sociedade cooperativa, a Resolução CFC nº. 920, de 2001, aprovou a NBC T 10, que trata dos Aspectos Contábeis Específicos em Entidades Diversas. O item NBC T 10.8 - Entidades Cooperativas, assim dispõe:

10.8.4.1 - A denominação da Demonstração do Resultado da NBC T 3.3 é alterada para Demonstração de Sobras ou Perdas, a qual deve evidenciar, separadamente, a composição do resultado de determinado período, considerando os ingressos diminuídos dos dispêndios do ato cooperativo, e das receitas, custos e despesas do ato não-cooperativo, demonstrados segregadamente por produtos, serviços e atividades desenvolvidas pela Entidade Cooperativa (CFC, 2001).

\footnotetext{
${ }^{9}$ Lei no .6 .404 , de 1976, art. 187.

Art. 187. A demonstração do resultado do exercício discriminará:

I - a receita bruta das vendas e serviços, as deduções das vendas, os abatimentos e os impostos;

II - a receita líquida das vendas e serviços, o custo das mercadorias e serviços vendidos e o lucro bruto;

III- as despesas com as vendas, as despesas financeiras, deduzidas das receitas, as despesas gerais e administrativas, e outras despesas operacionais;

IV - o lucro ou prejuízo operacional, as outras receitas e as outras despesas (Redação dada pela Lei n 11.941 , de 2009).

V - o resultado do exercício antes do Imposto sobre a Renda e a provisão para o imposto;

VI - as participações de debêntures, empregados, administradores e partes beneficiárias, mesmo na forma de instrumentos financeiros, e de instituições ou fundos de assistência ou previdência de empregados, que não se caracterizem como despesa (Redação dada pela Lei $n^{0} 11.941$, de 2009).

VII - o lucro ou prejuízo líquido do exercício e o seu montante por ação do capital social.

$\S 1^{\circ} \mathrm{Na}$ determinação do resultado do exercício serão computados:

a) as receitas e os rendimentos ganhos no período, independentemente da sua realização em moeda; e

b) os custos, despesas, encargos e perdas, pagos ou incorridos, correspondentes a essas receitas e rendimentos.
} 
$\mathrm{Na}$ análise desses dispositivos, verifica-se que houve modificação na denominação dessa demonstração financeira, que passou de Demonstração do Resultado do Exercício (DRE) para Demonstração de Sobras e Perdas (DSP), e, ainda, a divisão da apuração do resultado do exercício em: ato cooperativo correspondente aos ingressos diminuídos dos dispêndios; ato não cooperativo vinculando as receitas e diminuídas dos custos de despesas.

Embora essa metodologia permita que seja demonstrada, de forma segregada por produtos, serviços e atividades desenvolvidas pela sociedade cooperativa, a apuração das sobras líquidas ou das perdas líquidas decorrentes do ato cooperativo, assim como a apuração do lucro ou prejuízo contábil, vinculados ao resultado nas operações denominados de ato não cooperativo, a sociedade cooperativa de produção agropecuária deve elaborar as demonstrações financeiras.

Posteriormente, foi editada a Resolução CFC n ${ }^{\circ} .959$, de 2003, que aprovou a NBCT 10.21 IT - Regulamentação do item 10.21.4 - Demonstração de Sobras e Perdas. A DRE tem previsão legal no caput da Lei no 6.404 (BRASIL, 1976) e no Código Civil - Direito de Empresa (BRASIL, 2002), de que se infere, com clareza e certeza a realidade econômica das sociedades em geral.

Da leitura dessas disposições que tratam da demonstração financeira, extraem-se os significados que exigem a realização de abordagens resumidas, a fim de que sejam elucidados os aspectos relevantes, concernentes à quantificação e qualificação das sobras e perdas líquidas e dos lucros ou prejuízos contábeis apurados pelas sociedades cooperativas de produção agropecuárias e agroindustriais.

De início, cabe o registro que a modificação da denominação de DRE para DSP não traz nenhuma consequência prática na apuração da realidade econômica da sociedade cooperativa de produção agropecuária, principalmente se ficar evidenciado, nos registros da escrituração, com a devida comprovação, que a entidade apenas realizou operações típicas com os cooperados.

Em havendo operações definidas, como o ato não cooperado, a DRE deverá representar receitas, custos e despesas por produtos, serviços e atividades desenvolvidas pela sociedade cooperativa. Neste caso, a mudança de denominação para DSP incluiria, também, o resultado 
apurado nas operações decorrentes de ato não cooperado, o que poderia resultar em controvérsias desnecessárias na quantificação e qualificação dos valores apurados para fins societários, ou mesmo no interesse dos cooperados. Frequentemente, essas demonstrações são confundidas como se fossem sinônimas. Todavia, são designações bem distintas. O resultado apurado pela sociedade cooperativa de produção agropecuária na DRE deve ser segregado, a fim de evidenciar o valor que decorre do ato cooperativo, denominado de sobras ou perdas líquidas; e o ato não cooperativo, denominado de lucro ou prejuízo.

Portanto, a DRE tem por objetivo exprimir com clareza a situação patrimonial da sociedade cooperativa e as mutações ocorridas em determinado período. Tudo deve ser apresentada de forma clara, com a utilização de uma metodologia que permita apurar sobras ou perdas líquidas decorrentes do ato cooperativo e do lucro ou prejuízo contábil resultante das operações realizadas com não cooperados.

\subsubsection{Lucros ou prejuízos acumulados}

A conta de lucros ou prejuízos acumulados origina-se na DRE. Pela conceituação, decorre do ato não cooperativo. Quando o resultado for positivo (lucro), após o pagamento do imposto de renda pessoa jurídica e da contribuição social sobre o lucro líquido, deverá ser destinado integralmente para a Reserva de Assistência Técnica, Educacional e Social (Rates), não podendo ser objeto de rateio entre os cooperados (BRASIL, 1971).

Quando o resultado for negativo (prejuízo), decorrente de ato não cooperativo, o resultado será absorvido pela reserva legal. Se esta for insuficiente para absorver o prejuízo, a sociedade cooperativa de produção agropecuária poderá utilizar as sobras líquidas, após as destinações obrigatórias (BRASIL, 1971).

No entanto, se forem insuficientes essas compensações, o prejuízo será rateado entre os cooperados, conforme disposições estatutárias e legais, não devendo haver saldo pendente ou acumulado de exercício anterior, registrando tudo contabilmente na conta do ativo: prejuízos contábeis a receber de cooperados. 
As disposições da NBCT 10.8 que versam sobre o lucro ou prejuízo têm sido aperfeiçoadas pela doutrina e são informativos relevantes para conhecimento interno e externo da organização cooperativa, como a seguir:

O tratamento disposto na norma para o resultado do ato não cooperativo complementa e esclarece o disposto no artigo 87 da Lei $n^{\circ} 5.764$, de 1971. Então, o resultado positivo do ato não cooperativo é creditado integralmente em Reserva de Assistência Técnica, Educacional e Social - RATES. Se as operações do ato não cooperativo resultarem em prejuízos, a norma dispõe que deve ser debitado na conta de Reserva Legal, ou seja, não cabe a compensação (o débito) na conta RATES, mesmo que tenha saldo para absorver a totalidade do resultado negativo, porque a RATES tem finalidade específica, ou seja, os recursos destinados devem ser aplicados em programas de capacitação e promoção social da sociedade, que visa o desenvolvimento das pessoas e ainda dos funcionários colaboradores, se houver essa previsão no estatuto social (MEM, 2006).

Dessa forma, as observações pautadas na norma permitem afirmar que há uma vedação de qualquer possibilidade de compensar entre si os seguintes resultados: perdas líquidas (ato cooperativo) com lucro (ato não cooperativo); prejuízo (ato não cooperativo) diretamente com as sobras líquidas (ato cooperativo); prejuízo (ato não cooperativo) com saldo positivo da conta Rates, de modo que os recursos existentes nessa conta sejam efetivamente aplicados no desenvolvimento do programa de capacitação dos cooperados e funcionários colaboradores. A seguir, o Quadro 2 mostra a apuração econômica do resultado da sociedade cooperativa.

Quadro 2- Demonstração do resultado do exercício*

\begin{tabular}{|l|l|l|}
\hline \multicolumn{1}{|c|}{ Contas } & \multicolumn{2}{c|}{ Operações realizadas } \\
\cline { 2 - 3 } & \multicolumn{1}{|c|}{ Cooperados } & \multicolumn{1}{c|}{ Não cooperados } \\
\hline $\begin{array}{l}\text { Especificadas no plano contábil } \\
\text { das sociedades cooperativas em geral }\end{array}$ & Não incidência dos Tributos & \multicolumn{1}{c|}{ Incidência dos Tributos } \\
\hline Resultado do exercício & Sobras líquidas/perdas líquidas & $\begin{array}{l}\text { Lucro/prejuízo contábil do } \\
\text { exercício }\end{array}$ \\
\hline $\begin{array}{l}\text { (-) Provisão para Contribuição Social } \\
\text { sobre o Lucro Líquido - CSLL }\end{array}$ & $\begin{array}{l}\text { Prejuízos contábeis cobertos } \\
\text { pelo fundo de reserva }\end{array}$ & $\begin{array}{l}\text { (-)Provisão para Contribuição } \\
\text { Social sobre o Lucro Líquido - } \\
\text { CSLL }\end{array}$ \\
\hline $\begin{array}{l}\text { (-) Provisão para o Imposto de Renda } \\
\text { Pessoa Jurídica - IRPJ }\end{array}$ & Mediante rateio entre associados & $\begin{array}{l}\text { (-)Provisão para o Imposto de } \\
\text { Renda Pessoa Jurídica - IRPJ }\end{array}$ \\
\hline Resultado após a CSLL / IRPJ & Sobras líquidas & Lucro/prejuízo exercício \\
\hline
\end{tabular}

(*) Demonstração de apuração das sobras ou perdas líquidas - ato cooperado -, e do Lucro ou Prejuízo Contábil - ato não cooperado

Fonte: Autor

No patrimônio líquido, as reservas estão classificadas em: reservas de capital representada por valores recebidos que não transitam por resultado do exercício como receitas; reservas de lucros representadas por lucros obtidos pela entidade e retidos com finalidade específica, incluída a reserva legal conforme determina a Lei no 6.404 no art. 193, cuja utilização está restrita à compensação de prejuízos contábeis e ao aumento de capital social (BRASIL, 1976). 
A Lei $n^{0} 5.764$ no art. 28 prevê a criação de outros fundos, sem determinar os aspectos específicos de sua utilização (BRASIL, 1971).

As reservas de capital representam aumento patrimonial sem, porém, ter transitado pelo resultado do exercício, por não representar esforço efetivo na realização de receitas. A movimentação dessas contas no patrimônio líquido da sociedade cooperativa de produção agropecuária origina-se de doações e subvenções para investimentos que eram realizadas.

Muitos são os tipos de doação e subvenção para investimentos, sendo mais comuns as doações em dinheiro ou em bens imóveis ou direitos; e as subvenções, em forma de recursos concedidos, são destinadas à aplicação em imobilização ou em forma de redução de tributos.

Entretanto, ao ser modificada a estrutura do patrimônio líquido, foi incluída a forma de registro das doações e subvenções para investimentos, não mais permitindo seu registro diretamente numa conta de reserva de capital, devendo transitar pelo resultado do exercício para posterior transferência à reserva de lucros - reservas de incentivos fiscais. O Comitê de Pronunciamentos Contábeis, a partir do IAS 20 do IASB, aprovou o Pronunciamento Técnico CPC 07 - Subvenção e Assistência Governamentais, que culminou com a Resolução do CFC $\mathrm{n}^{\mathrm{o}} 1.305$, que veio estabelecer esses novos critérios de registros contábeis específicos, a partir do exercício financeiro de 2008 (CFC, 2010).

“(...) as doações e subvenções recebidas pela companhia deverão transitar pelo resultado, e terão seus registros contábeis determinados em função das condições estabelecidas para o recebimento dessas doações e subvenções." Estes autores classificam as subvenções e doações da seguinte forma: tratamento contábil quando a subvenção é condicional; tratamento contábil quando a subvenção é incondicional; benefício sobre a forma de redução ou isenção tributária; tributos financiados pelo Estado; incentivo fiscal de imposto de renda (Finam/Finor); constituição de reserva de incentivos fiscais. IUDÍCIBUS et alii (2010, p. 356)

\subsubsection{Sobras ou perdas líquidas}

As pessoas jurídicas mercantis que atuam nos diversos ramos econômicos manejam sempre a contingência de, ao final do exercício financeiro, deparar com resultados positivos ou negativos. Nessas pessoas jurídicas, o resultado positivo se converte em lucro - que é o próprio fim da atuação desse modelo societário. Com as sociedades cooperativas não é 
diferente; todavia, estas devem ter como objetivo a busca do resultado decorrente do ato cooperativo denominado de sobras líquidas.

Nesse sentido, passa a ser relevante o conceito vinculado à modalidade de sociedade cooperativa para as sobras líquidas:

(...) sobras líquidas, na linguagem cooperativa, designa os próprios lucros líquidos, os lucros apurados em balanço, que devam ser distribuídos sob a rubrica de retorno ou como bonificações aos asssociados, não em razão das cotas-partes de capital, mas em conseqüências das operações ou negócios por elas realizadas na cooperativa. As sobras líquidas ou retorno, portanto, funcionam como uma restituição proporcional ao valor das compra efeturadas pelos próprios cooperados, que lhes é atribuída a título de bonificação. (DE PLÁCIDO E SILVA, 2003, p. 1309).

O conceito de sobras líquidas também pode decorrer do confronto de receita e despesa:

(...) lucros líquidos ou superavit entre a receita e a despesa, apurado em balanço feito pelas cooperativas, que deve ser distribuído a título de bonificação, proporcionalemte ao valor dos negócios ou compras por eles realizadas, salvo se a assembléia as incorporar às reservas (DINIZ, 2005, p. 479).

A socieadade cooperativa não se constitui para obter lucros a repartir entre os cooperados, mas, sim, para lhes outorgar vantagens reveladas durante as atividades desenvolvidas de natureza econômica ora denominada de sobras líquidas. A compreensão desse fenômeno cooperativo é melhor explicada a seguir:

A cooperativa operando com a clientela associada no intuito de melhorar-lhe a situação econômica mediante serviços específicos que lhe presta, não têm a cooperativa razão para lucrar a suas expensas. Não é esse o caso das empresas do direito mercantil, cujo fim é alcançarem para seus integrantes uma renda proporcional ao capital investido, realizada por meio de negócios efetuados principalmente com terceiros e, eventualmente, com os próprios sócios, que nessas operações, se encontram na posição de terceiros.

Nas cooperativas, que operam em círculo fechado com clientela associada, as diferenças entre receitas e as despesas, apuradas nos balanços anuais, quando positivas, podem ter uma aparência de lucro. Na realidade, porém, trata-se de 'sobras' resultantes de haver o associado pago a mais pelo serviço que a cooperativa lhe prestou ou, inversamente, de ter ela retido um valor excessivo como contraprestação pelo serviço fornecido. As 'sobras', tecnicamente, não são 'lucros', mas saldo de valores obtidos dos associados para cobertura de despesas, e que, pela racionalização ou pela faixa de segurança dos custos operacionais com que a cooperativa trabalhou, não foram gastos, isto é 'sobraram', merecendo, por isso, a denominação de 'despesas poupadas' ou 'sobras'.

Ora, corresponde a uma exigência de justiça distribuitiva que as 'sobras' sejam devolvidas aos cooperados na mesma medida em que estes contribuíram para sua formação. A idéia da devolução das sobras aos associados na proporção das operações que tenham feito com a sociedade, deu nascimento ao instituto jurídico do 'retorno', o qual, no dizer de GIDE, constitui no quadro das conquistas sociais 
contemporâneas uma das criações mais geniais do século XIX, legada ao mundo pelos equidosos pioneiros de Rochadale. Revela, porém, notar que nada impede que, em vez de retornar as sobras, a cooperativa destine, por inteiro ou em parte, a um fundo de reserva indivisível, o qual, na observação de LAVERGENE, constituirá, assim, uma espécie de capital corporativamente socializado (FRANKE, 1973, p. 1920).

Tais considerações em nada modificam o significado da expressão sobras líquidas na linguagem do direito cooperativo, porque também designa o resultado positivo apurado no exercício financeiro pela sociedade cooperativa na DRE (ou DSP) decorrente do ato cooperativo. As sobras líquidas podem ser creditadas ou distribuídas aos cooperados e capitalizadas, quando assim dispuser o estatuto, não em razão das quotas-partes de capital, mas em consequência das operações ou negócios dos cooperados realizados com a cooperativa.

A propósito, quando há referência ao resulto líquido do exercício tem-se que,

(...) os resultados líquidos do exercício devem ser repartidos entre os associados, na proporção das operações que eles mantiverem durante o ano com a cooperativa. Essa repartição que os associados fizeram uso, nas cooperativas que agrupam produtores, possuidores de matéria-prima, ou consumidores; e do que foi pago a menos, a título de salário, naquelas de possuidores de mão-de-obra, ou executores de serviços profissionais; e, em ambos os casos, tecnicamente, é chamada de RETORNO, ou princípio de Charles Howart (GREDILHA, 1945 apud FRANKE, 1973, p. 21).

Ao comentar o artigo 69 do código cooperativo português, que versa sobre reservas e distribuição de excedentes, o autor assim se manifesta:

\footnotetext{
Quanto à expressão "excedentes", trata-se de um termo do léxico sergiano: Dum modo um tanto simplista, quando chegamos ao fim do ano e verificamos que numa cooperativa o total das receitas excedeu o total das despesas, dizemos que houve sobras ou excedentes. Porém, para idêntica situação numa sociedade capitalista já nos exprimimos de maneira diferente e afirmamos que houve lucro. Os fins, a natureza e a organização da entidade cooperativa são diferentes do estabelecimento comercial tipo lucrativista e justificam as diferentes denominações para esta situação (DA COSTA, 1981, p. 89-90).
}

Os ensinamentos de Namorado (2000, p. 53) facilitam a compreensão das terminologias de natureza contábil relacionadas ao direito cooperativo, cujas distinções são necessárias, entre o lucro contábil e as sobras líquidas:

(...) do capital, e são repartidos entre os sócios na proporção do capital, Os retornos distribuídos pelas cooperativas não se confundem com os lucros 
distribuídos pelas sociedades lucrativas, ainda que uns e outros apresentem a característica comum de serem somas de dinheiro periodicamente repartidas entre os sócios. Os lucros representam uma remuneração com que cada um deles entrou. Os excedentes são pelo contrário, o equivalente monetário da vantagem mutualista nas cooperativas de consumo, de cuja prática nasceu o termo 'retorno', eles são o reembolso aos sócios do maior preço pago relativamente ao custo do bem ou do serviço recebido são, nas cooperativas de trabalho, somas atribuídas aos sócios para completar o menor salário recebido relativamente ao que levaram para a sociedade (GALVANO, 1978 apud NAMORADO, 2000, p. 136).

Para que se compreenda a diferença entre lucro contábil e sobras líquidas, explicada pelo autor, é mister que se dê relevância à análise dos princípios cooperativos que evidenciam o distanciamento entre as entidades cooperativas e sociedades comerciais empresárias pelo Código Civil brasileiro (BRASIL, 2002).

Ao retomar as discussões iniciais importa esclarecer o que se entende por sobras líquidas numa sociedade cooperativa, expressão ainda mal empregada para exprimir "lucro", explicada a seguir:

(...) nas cooperativas que operam em círculo fechado com os associados, as diferenças entre receita e despesa, apuradas nos balanços anuais, quando positivas, podem ter aparência de lucro. Na realidade, porém, trata-se de "sobras" resultantes de haver o associado pago a mais pelo serviço que a cooperativa lhe prestou ou, inversamente, de ter ela retido um valor excessivo como contraprestação o serviço fornecido (FRANKE, 1973 apud NASCIMENTO, 2000, op. cit.p. 79-80).

A expressão sobras líquidas, do ponto de vista das ciências contábeis, representa o resultado positivo apurado ao final do exercício social decorrente da prática de atos cooperativos pela sociedade cooperativa, ou seja, se suas receitas (ingressos) superarem os custos e despesas (dispêndios) tem-se como quantificadas. Explica-se: o sujeito econômico cooperativado, ao estabelecer com o mercado relação jurídica negocial, por meio da organização empresarial sociedade cooperativa, está realizando operações típicas que podem resultar em sobras líquidas apuradas ao final do exercício.

As sobras líquidas, quando apuradas pela sociedade cooperativa, apresentam o mesmo significado, ou seja, o resultado positivo entre a receita (ingressos) e os custos e as despesas (dispêndios). As sobras líquidas diferem de retorno. Este, na linguagem jurídica, representa regresso, volta, torna e reversão à origem (cooperado) de bens, direitos ou mesmo 
disponibilidades que não pertencem ao patrimônio da sociedade cooperativa, não dependendo de apuração de resultado contábil.

Portanto, à guisa de conceituação, pode-se inferir que as sobras líquidas decorrem do resultado econômico, jurídico e financeiro apurado na escrituração comercial da sociedade cooperativa, vinculando operações qualificadas como ato cooperativo. Os cooperados são os beneficiários das sobras líquidas.

A constituição de reserva depende da existência de valores, físicos ou monetários, a partir do qual se poderiam tirar quantidades para a formação de poupança de caráter espontânea. As reservas de sobras líquidas, por sua vez, podem ser agrupadas em três categorias: reserva legal, reserva de assistência técnica, educacional e social e outras reservas de sobras (estas últimas devem ser criadas em Assembleia Geral ou estar previstas no estatuto da cooperativa).

A reserva legal tem por finalidade assegurar a integridade do capital social e somente pode ser utilizada para compensar prejuízos ou aumentar o capital social. A proteção ao capital é feita por meio da utilização da reserva legal para compensação de eventuais prejuízos, evitando assim que o capital social seja atingido (BRASIL, 1976).

No Capítulo VII (Dos Fundos), a Lei no 5.764 estabelece que:

\begin{abstract}
Art. 28. As cooperativas são obrigadas a constituir:
I - Fundo de Reserva destinado a reparar perdas e atender ao desenvolvimento de suas atividades, constituído com 10\% (dez por cento), pelo menos, das sobras líquidas do exercício;

II - Fundo de Assistência Técnica, Educacional e Social, destinado a prestação de assistência aos associados, seus familiares e, quando previsto nos estatutos, aos empregados da cooperativa, constituído de 5\% (cinco por cento), pelo menos, das sobras líquidas apuradas no exercício.

$\S 1^{\circ}$ Além dos previstos neste artigo, a Assembleia-geral poderá criar outros fundos, inclusive rotativos, com recursos destinados a fins específicos fixando o modo de formação, aplicação e liquidação.

$\S 2^{\circ}$ Os serviços a serem atendidos pelo Fundo de Assistência Técnica, Educacional e Social poderão ser executados mediante convênio com entidades públicas e privadas (BRASIL, 1976).
\end{abstract}

A Resolução CFC n 920, que aprovou a NBC T 10.8, estabelece no item 10.8.1.12 que "Os fundos previstos na legislação ou nos estatutos sociais, nesta norma, são denominados reservas" (CFC, 2001). Ou seja, do ponto de vista contábil, as regulamentações são no sentido de que todos os fundos previstos nessa lei específica sejam denominados de reservas, 
representando as parcelas monetárias efetivas das sobras líquidas retidas durante o exercício financeiro. Essa conta do fundo de reserva possui tratamento semelhante à conta reserva legal, conforme determina a Lei $n^{\circ} 6.404$ (BRASIL, 1976). Aceita a conceituação, a formação de reserva dependeria da existência de sobras líquidas.

O fundo de reserva possui duas destinações bastante específicas, quais sejam, reparar perdas, assemelhando-se à compensação de prejuízos, e atender ao desenvolvimento das atividades, que pode ocorrer com o aprimoramento da tecnologia da informação utilizada pela sociedade cooperativa, entre outras. Esse fundo é composto por, no mínimo, 10\% das sobras líquidas do exercício, podendo o estatuto dispor de modo contrário, elevando tal percentual até o máximo de $95 \%$ (BRASIL, 1971).

A determinação da lei para criação do Fates ${ }^{10}$ tem como origem os princípios dos pioneiros de Rochdale: dos ganhos, uma parcela seria destinada a um fundo para educação dos membros cooperados. Esse princípio, que perdura até hoje, foi editado no congresso da ACI realizado em Manchester em 1995: Educação, treinamento e informação: dos associados, dos representantes eleitos, dos executivos e empregados da cooperativa para que eles possam, efetivamente, contribuir para seu desenvolvimento. Além disso, a natureza e os benefícios do cooperativismo devem estender-se ao público, em especial aos jovens e líderes da comunidade (PINHO, 1995).

Para Namorado (2000), este é um princípio verdadeiramente estratégico, da maior importância como fator de legitimação social da cooperatividade e como elemento de divulgação das experiências cooperativas.

O Fates configura-se numa retenção de sobras líquidas, indivisível (não distribuível aos cooperados), que serão utilizadas para um propósito específico: prestação de assistência aos associados e familiares e, quando previsto no estatuto da cooperativa, aos empregados dela. É verdadeira expressão econômica do princípio cooperativo do investimento na educação dos associados, contribuindo para a formação de um patrimônio comum destinado a promover o crescimento pessoal e social dos associados e familiares, facultando a extensão da utilização

\footnotetext{
${ }^{10}$ Os recursos do Fates são utilizados em três atividades: assistência técnica, assistência educacional e assistência social.
} 
da finalidade aos empregados da sociedade cooperativa desde que exista previsão estatutária nesse sentido.

Ademais, a Resolução CFC no 920 menciona os seguintes tratamentos aplicáveis para o "resultado líquido decorrente do ato não cooperativo":

10.8.2.6 - O resultado líquido decorrente do ato não-cooperativo, quando positivo, deve ser destinado para a Reserva de Assistência Técnica, Educacional e Social, não podendo ser objeto de rateio entre os associados. Quando negativo, deve ser levado à Reserva Legal e, se insuficiente sua cobertura, será rateado entre os associados (CFC, 2001).

Em relação ao Fates, a Lei $n^{0} 5.764$ estabelece que deve ser destinada à prestação de assistência aos associados e familiares e, quando previsto nos estatutos, aos empregados da cooperativa, constituído de 5\%, pelo menos, das sobras líquidas apuradas no exercício e todos os resultados das operações das cooperativas com não associados (BRASIL, 1971).

Portanto, a reserva de assistência técnica, educacional e social pode receber recursos de duas "fontes": resultado líquido decorrente do ato não cooperativo e sobras líquidas.

\subsubsection{Ajustes de avaliação patrimonial}

Esta conta é uma inovação trazida para a contabilidade brasileira com o objetivo claro de receber as contrapartidas de aumentos ou diminuições de valor atribuído a elementos do ativo e do passivo em decorrência de avaliação a valor justo ${ }^{11}$ enquanto não computadas no resultado do exercício, em obediência ao regime de competência, conforme determina o art. 37 da Lei ${ }^{0} 11.941$ (BRASIL, 2009). Iudícibus e Martins (2007) discutem com profundidade o conceito de valor justo e apresentam as diversas facetas de aplicação, relatando que o

\footnotetext{
${ }^{11}$ É o montante pelo qual um ativo poderia ser trocado, ou um passivo liquidado, entre partes independentes com conhecimento do negócio e interesse em realizá-lo, em uma transação em que não há favorecidos. Da normatização, surgem as seguintes definições: valor justo (fair value),é o valor pelo qual um ativo pode ser negociado ou um passivo liquidado entre partes interessadas, conhecedoras do negócio e independentes entre si, com a ausência de fatores que pressionem para a liquidação da transação ou que caracterizem uma transação compulsória; valor justo tem como primeiro objetivo demonstrar o valor de mercado de determinado ativo ou passivo; na impossibilidade disso, demonstrar o provável valor que seria o de mercado por comparação a outros ativos ou passivos que tenham valor de mercado; na impossibilidade dessa alternativa também, demonstrar o provável valor que seria o de mercado por utilização do ajuste a valor presente dos valores estimados futuros de fluxos de caixa vinculados a esse ativo ou passivo; finalmente, na impossibilidade dessas alternativas, pela utilização de fórmulas econométricas reconhecidas pelo mercado (BRASIL, 1976), art. 183, § $1^{\circ}$, com a redação modificada pela Lei n ${ }^{\circ} 11.638$ e n ${ }^{\circ} 11.941$ (BRASIL, 2007, 2009); CPC 14 ; CFC no 1.151 e n ${ }^{\circ} .1 .153$, de 2009).
} 
conceito e aplicação de valor justo representam, sem dúvida, uma espetacular, agressiva e, de certo modo, algo como uma arriscada virada no que se refere à avaliação contábil.

Portanto, a utilização desse conceito nas demonstrações contábeis das sociedades cooperativas de produção agropecuárias e agroindustriais representa um grande desafio aos preparadores, analistas e auditores. A conta do ajuste de avaliação patrimonial não corresponde a uma conta de reserva, uma vez que seus valores não transitaram pelo resultado. Sendo assim, ela não deverá ser considerada quando do cálculo do limite referente à proporção das reservas de lucro em relação ao capital. Como regra geral, os valores registrados nessa conta deverão ser transferidos para o resultado do exercício à medida que os ativos e passivos forem sendo realizados (IUDÍCIBUS et alii, 2010, p. 50).

\subsection{SOCIEDADE COOPERATIVA E A GERAÇÃO DE RESULTADO ECONÔMICO E FINANCEIRO}

A fundamentação teórica exige critérios a serem observados na elaboração das principais contas e subcontas das demonstrações financeiras, balanço patrimonial e a apuração do resultado do exercício, com ênfase nas atividades operacionais das sociedades cooperativas de produção agropecuárias, inclusive, as agroindustriais, quanto à finalidade básica para diagnosticar aquelas que são responsáveis pelo aumento ou redução de receitas, de custos ou despesas, sobras líquidas e lucros.

Para realizar esta análise econômica, busca-se conhecer qual a capacidade da organização para gerar resultados positivos no período atual, e nos próximos anos, de forma gradual, segura e rentável, autossustentando as atividades operacionais. Isso requer uma avaliação dos ganhos obtidos pela sociedade cooperativa de produção agropecuária a partir da diferença positiva entre receitas e custos totais das atividades-fim e, principalmente, pelo comportamento das sobras líquidas, tendo em vista os elementos que compõem o patrimônio líquido dessa organização.

A situação econômica pode ser analisada de forma estática, quando se considera o montante dos recursos próprios investidos pelos cooperados, representada pela expressão monetária 
dentre os valores alocados no ativo da organização; e de forma dinâmica, pela evolução máxima ocorrida no patrimônio, com a formação das sobras líquidas, e política de sua retenção ao longo de determinado período de tempo. Em termos práticos, a sociedade cooperativa de produção agropecuária deve apresentar um montante adequado de capital próprio em decorrência dos recursos aplicados e, além de aumentar esse capital social, por meio de reinvestimento das sobras líquidas ou pela entrada de novos cooperados, garantir ganhos econômicos e financeiros para alavancar o desenvolvimento dos negócios.

De outro lado, cabe registrar que os eventos econômicos poderão ser influenciados de várias formas, desde uma parada parcial ou total das atividades da organização, tendo como fatores mais comuns o aparecimento de um novo ou grande concorrente no mercado, à perda de uma ou mais safras por externalidades negativas, como é o caso das questões climáticas, ou ainda, por defasagem nos preços dos produtos, sujeitos ao controle de política governamental, podendo resultar em perdas líquidas que podem comprometer o desenvolvimento da organização com prejuízo aos cooperados.

Por sua vez, a sociedade cooperativa de produção agropecuária pode gerar, por meio de provimento de uma rede de segurança, as condições necessárias para que o cooperado garanta a continuidade na geração de renda, através das operações inerentes à exploração da atividade rural, consequentemente, permitirá que as políticas sejam favoráveis e suficientes para oportunizar os ganhos indiretos.

É imprescindível o conhecimento das causas que afetam o resultado obtido pela sociedade cooperativa de produção agropecuária em determinado espaço temporal, como também a análise da comparação de desempenho em determinado ano com os ganhos auferidos em anos anteriores, ou mesmo com resultado do segmento agropecuário objeto da organização, pois tudo isso faz parte do processo de análise econômica, que deve ser observado no contexto de geração de resultado, sob pena de frustrar o real beneficiário, que é o cooperado.

Dessa forma, para subsidiar o estudo de caso realizado serão utilizados como fonte primária os dados colhidos em entrevistas com especialistas de cada organização, informações que irão permitir visualizar e analisar as contas do patrimônio líquido, classificadas sob o título de Reservas do Fates, Sobras Líquidas e Lucros Acumulados de quatro sociedades cooperativas 
de produção agropecuárias, inclusive, as agroindustriais localizadas no Estado do Rio Grande do Sul, cujos objetos sociais selecionados são diversos, como segue:

a) recebimento, industrialização e comercialização da soja, milho e trigo;

b) recebimento de arroz de forma integrada com o cooperado, posteriormente industrializado, e a comercialização do grão no mercado interno e externo;

c) recebimento de soja in natura do cooperado para industrialização e comercialização no mercado interno; e

d) recebimento da produção de uva do cooperado para industrialização e comercialização no mercado interno e externo.

Assim, a coleta das informações foi realizada por meio de entrevista(Apêndice 1), cujos respondentes foram escolhidos entre os profissionais especializados das organizações, principalmente daqueles setores responsáveis pelo controle administrativo das políticas de distribuição e/ou capitalização e da formação do Fates.

\subsubsection{Ganhos competitivos de eficiência}

A sociedade cooperativa de produção agropecuária, como um nexo de contratos Alchian e Demsetz (1972), recebe recursos de cooperado pessoa física, que retornarão na forma de resíduos decorrentes do resultado da exploração de suas atividades operacionais. Ela é integrada, ainda, por contratos de outros tipos, que representam eventos de diversas naturezas, como os contratos de aquisição de produtos agropecuários dos cooperados, de fornecimento de matéria-prima, de compra de máquinas e equipamentos, de contratação de mão de obra, de financiamentos, entre outros.

Para cumprir o contrato com seu cooperado (o proprietário dos resíduos), a sociedade cooperativa transforma recursos com agregação de valores e os negocia com os mercados interno e externo, atribuindo ao produto transformado (ou produzido) uma mais valia ou ganho. A sociedade cooperativa e o mercado realizam a transação que resulta em geração de valor classificada como receita ou faturamento. Na obtenção dessa receita, a organização 
registra o fato econômico e financeiro no seu patrimônio, a riqueza gerada dessas operações e, assim, sucessivamente.

No processo empresarial (aquisição, industrialização, comercialização de produtos agropecuários e a administração) a sociedade cooperativa consome os mais diversos recursos. Para tanto, adquire de fornecedores direitos sobre esses recursos (produtos, insumos e máquinas e equipamentos), variando, esses direitos, desde uso até domínio pleno. Partindo desses recursos, em um momento posterior, a sociedade cooperativa possuirá direitos sobre os produtos por ela originados. A sociedade cooperativa é um nexo de contratos que transaciona direitos de propriedade, buscando a eficiência de cada operação e atendimento dos objetivos e interesses dos cooperados pessoas físicas. Esses direitos têm intensidade, complexidade e características específicas que os diferenciam.

Por sua vez, a eficiência está condicionada à vantagem competitiva a ser alcançada ao longo da atividade desenvolvida. Em termos competitivos, Porter (1989) enfatiza que as diferenças entre cadeias de valores concorrentes são uma fonte básica de vantagem competitiva. Para o autor, o valor é medido pela receita total, reflexo do preço que o produto de uma empresa impõe e as unidades que ela pode vender. Criar valor para os compradores, que exceda o custo operacional da organização, é a meta de qualquer estratégia genérica, inclusive, das próprias sociedades cooperativas.

Machado Filho et alii (1999) e Conejero et alii (2003) levantam, a partir de uma análise de forças, fraquezas, oportunidades e ameaças do sistema cooperativo no Brasil, os seguintes eixos estratégicos a serem priorizados pelas sociedades cooperativas:

Focalização em negócios estratégicos; [...]; aumento da eficácia dos modelos de gestão; profissionalização e equacionamento do processo sucessório; otimização do processo de tomada de decisão; equacionamento da relação com cooperados; otimização das estruturas administrativas; fortalecimento da capacidade em lidar com o mercado. Profissionalização em marketing; Otimização da estrutura de capital. Reestruturação de passivos e aumento da eficiência em capitalização e captação de recursos. MACHADO FILHO (1999, p. 155) CONEJERO (2003, p. 68).

Destes eixos, procurou-se identificar algumas contribuições para o modelo administrativo das 
sociedades cooperativas, competitivos e essenciais para o presente estudo: "focalização em negócios estratégicos", "equacionamento da relação com cooperados", "controle societário de sociedade não cooperativa" e "vantagens competitivas" - Good Will trust."

Em relação aos negócios estratégicos, a sociedade cooperativa deve converter as adequações de combinação de atividades desenvolvidas de valor para conseguir custos menores, colaboração entre as entidades para criar novos recursos e capacitações e as transferências de aptidões em vantagens competitivas.

Independentemente da estratégia que adote, a sociedade cooperativa tem modos alternativos para estruturar-se internamente ou de relacionar-se com os cooperados e com o mercado interno ou externo. A estrutura organizacional passa a ser relevante, porque a informação necessária para gerir uma sociedade cooperativa não é completa e os contratos interno e externo apresentam custos ao serem administrados e suportados. Assim, é necessário que se organize de modo a lidar eficientemente com esse problemas de informações e/ou contratuais para enfrentamento da concorrência, seja pela utilização de instrumento de controle societário com a sociedade não cooperativa, pela confiança em cooperação interorganizacional, orgulho e pertencimento, estratégicas capazes de proporcionar em ganho indireto para os cooperados.

A transação econômica, fruto da transferência parcial ou total de direitos, ocorre mediante o recorte dos direitos absolutos pelos relativos (condições contratuais). E é esse recorte que denominamos de rearranjo de direitos de propriedade. Ou seja, além da simples e total transferência de bens - como no escambo - necessita-se uma reorganização de direitos e responsabilidades relacionados a um determinado produto, entre partes negociantes, acrescentando utilidades a elas. Essa transação objetiva cria a expectativa - ex ante - em cada parte de uma mais-valia, o que motiva a realização da transação típica de negócio cooperativo.

Nesse ponto, deve-se ressaltar que o ensaio foca as transações entre sociedades (geradoras de receitas efetivas). Afinal, pode-se questionar que nas transações intrasssocietárias (isto é, transações firmadas entre áreas ou divisões de uma mesma entidade, como fases do processo 
produtivo), também ocorrem cessão de recursos alocados sob suas respectivas responsabilidades, onde a distribuição da mais-valia caminha próximo ao conceito de preço de transferência dos produtos. Portanto, deixa-se claro que os aspectos abordados se restringem a transações entre entidades distintas, e que o foco é a geração efetiva de receita numa transação reconhecida por terceiros, e não com relação a preços de transferência de produto intrassociedades, seja cooperativa ou não cooperativa.

Desse modo, na transferência de direitos, temporária ou permanente, uma sociedade cooperativa cede a outra, um subconjunto de direitos relativos a um produto. Em contrapartida, a outra entidade não cooperativa cede um titulo de crédito ou dinheiro. A receita é a contrapartida pelo conjunto de direitos de propriedade rearranjado. Portanto, a receita não é o valor econômico final da transação, afinal, a receita é definida ex ante, pois apenas as expectativas identificadas pelas partes é que estão incluídas no preço.

\subsubsection{Escopo competitivo}

\subsection{Coalizão das sociedades cooperativas}

A sociedade cooperativa pode buscar o benefício de um escopo mais amplo firmando coalizões com sociedades não cooperativas para alcançar alguns dos benefícios econômicos ou financeiros. Porter (1989) aduz que as coalizões são acordos a longo prazo entre empresas que extrapolam transações de mercado normais, mas que necessariamente não chegam a ser fusões totais.

As coalizões são formas de ampliar o escopo sem ampliar a empresa, contratando uma empresa independente para executar atividades de valor (por exemplo, um acordo de fornecimento) ou unindo-se a uma empresa independente para compartilhar atividades (por exemplo, uma sociedade em cota de participação de marketing). Assim existem dois tipos básicos de coalizão - coalizões verticais e coalizões horizontais. (PORTER, 1989, p. 52) 
$\mathrm{O}$ ambiente institucional brasileiro permite que a sociedade cooperativa em geral constitua arranjos como a participação societária em outras sociedades não cooperativas públicas e privadas. $\mathrm{O}$ art. 88 da Lei $\mathrm{n}^{\mathrm{o}} 5.764$ (BRASIL, 1971), alterada pelo art. 13 da Medida Provisória $\mathrm{n}^{\mathrm{o}}$ 1.961-25, (BRASIL, 2000), passou a vigorar com a seguinte redação:

Art.88. Poderão as cooperativas participar de sociedades não cooperativas para melhor atendimento dos próprios objetivos e de outros de caráter acessório ou complementar. (NR) (Grifei)

Essa nova redação eliminou a exigência prévia e expressa de autorização, concedida pelo respectivo órgão executivo federal, consoante às normas e limites instituídos pelo Conselho Nacional de Cooperativismo. E, ainda, dispensou o caráter excepcional da participação em sociedades não cooperativas públicas ou privadas, e estabeleceu a obrigatoriedade de que as inversões decorrentes dessa participação sejam contabilizadas em títulos específicos e seus eventuais resultados positivos levados ao Fates. Entretanto, mantém-se unicamente a necessidade de que a sociedade cooperativa participe de outras sociedades com a finalidade de atender seus próprios objetivos e de outros de caráter acessório ou complementar. A representação gráfica, na figura $n^{0} 3$, permite que se visualize graficamente a forma como se processa a coalizão entre a sociedade cooperativa e a sociedade empresarial para criação de atividade de valor.

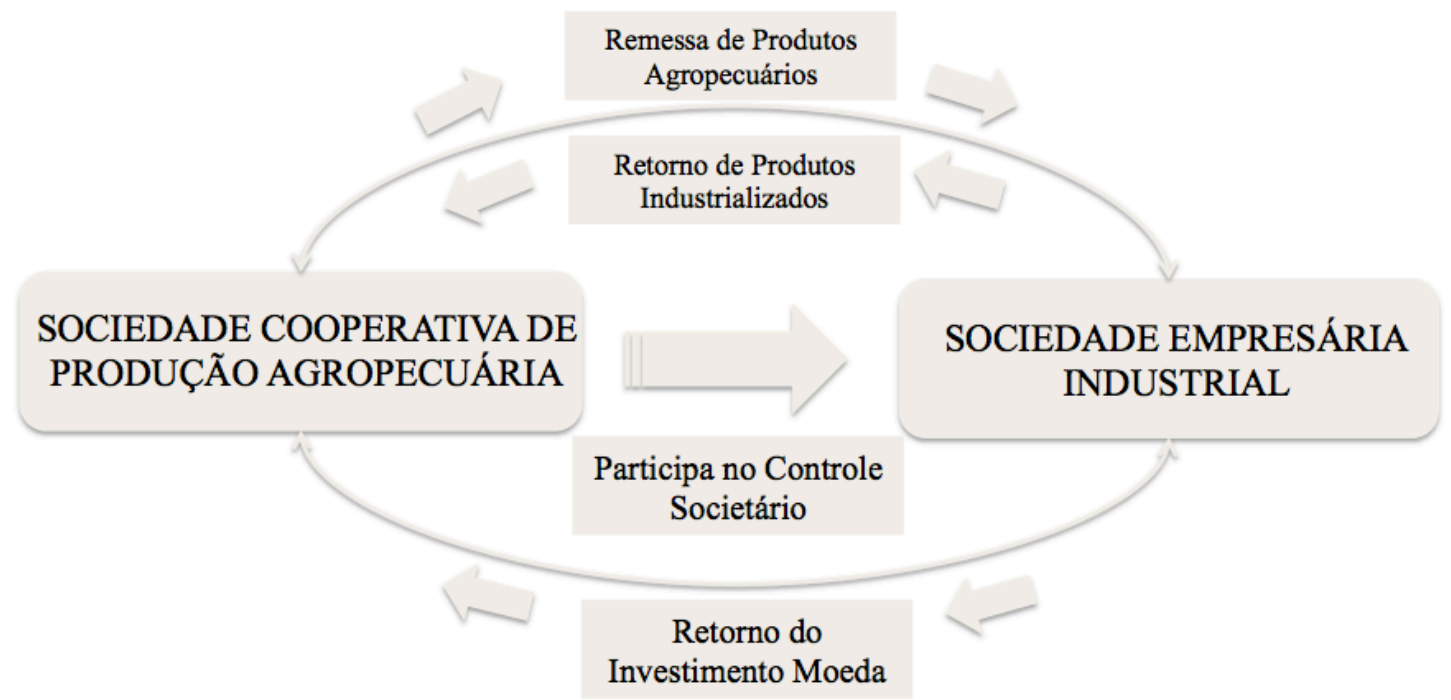

Figura 3 - Coalização de Sociedade Cooperativa Fonte: Autor 
Por conseguinte, as sociedades cooperativas de produção agropecuária podem utilizar, como uma das estratégias competitivas, a participação societária em outras sociedades não cooperativas, e o resultado decorrente, seja, por exemplo, na forma de retorno de produtos agropecuários agregados, decorrentes da industrialização por encomenda, ou em retorno com ganho de investimentos, e que podem contribuir para o aumento de receita ou redução dos custos e despesas de natureza operacionais.

\subsection{Sociedades cooperativas e as vantagens competitivas}

\subsection{Goodwill trust, orgulho e o pertencimento}

Fomentar a competitividade em mercados cada vez mais acirrados e, ao mesmo tempo, globalizados, é uma tarefa de grande importância na atualidade. Para implementá-la, torna-se necessário ter a percepção das relações de confiança, inseridas no ambiente organizacional das sociedades cooperativas. O campo de aplicação do good will trust é de tal maneira vasto e variadíssimo nas hipóteses que comportam sua utilização. Não há regras que dificultem ou restrinjam a constituição do instituto, que pode ser utilizado para uma variedade ilimitada de objetivos. A par da utilidade do good will trust como mecanismo para administração, garantia ou investimento, sua aplicação se mostra útil a ativos das sociedade cooperativas de produção agropecuária, nas atividades negociais interna ou externa e é uma das fontes da vantagem competitiva.

Sob a ótica de Hess (2003) e Porter (2009), a proximidade espacial entre as organizações facilita relações baseadas em confiança, visto que a sua construção é, usualmente, difícil de se obter de relações distantes, porque não gozam dos benefícios da interação face a face. $\mathrm{Na}$ visão de Harrisson (1991), graças à confiança, as empresas são capazes de promover ações conjuntas. Para esse autor, existe uma cadeia de relação causal, em que a proximidade leva à experiência que, por sua vez, leva à confiança, que leva à cooperação, e assim incrementa o crescimento regional dos agentes econômicos.

Segundo Jarrilo (1998), quando a confiança é solidificada nas empresas, os mecanismos elevados dos custos econômicos são diminuídos grandemente. Isso se dá através da prevenção 
e correção de comportamentos oportunísticos, que destroem a reputação, cujo valor econômico é enorme para sustentar relações. Nooteboom (1999) chama a atenção que a confiança só fará sentido, se for além do egoísmo não prejudicando principalmente a inovação em rede.

Na cooperação interorganizacional, um aspecto de grande importância é o papel da confiança. Para Granovetter (1985), por exemplo, a confiança é um valor traçado por normas sociais, ou seja, é um subproduto da inserção (embeddedness) das partes que compartilham uma norma cultural e social comum.

Na mesma linha, Zucker (1986) declara que a confiança é socialmente produzida em três tipos: (i) a confiança baseada em processo; (ii) em compartilhamento de características comuns; e (iii) a baseada em instituições. No primeiro tipo, a confiança é baseada em processo e surge quando as relações se mostram estáveis, ao longo do tempo, sendo desenvolvida com base na experiência de trocas passadas, porque quem confia também acredita que o parceiro continuará o seu comportamento como sempre fez, e porque, a produção de confiança surge por meio de esforço mútuo de investimento em confiança, ou de expectativas ligadas às trocas futuras, por ser uma estimativa probabilística de que as mesmas ações serão empreendidas.

No segundo tipo, a confiança é baseada no compartilhamento de características comuns, como laços familiares, religião, ética e cultura. Para o Zucker (1986), esse tipo de confiança existe a partir de questões de identidade em sociedades menos industrializadas, onde o costume desempenha um papel mais relevante e a cooperação será provavelmente mais fácil entre as pessoas que tenham as mesmas normas culturais.

A confiança, no terceiro tipo, o autor explica que é baseada nas instituições, onde os mecanismos institucionais formais fornecem códigos ou garantias de que as transações acontecerão como prometidas. Para Child e Faulkner (1998), esses mecanismos institucionais incluem leis para efetuar contratos, supervisão de agências governamentais e sanções por 
violação de normas sociais e a existência de instituições e agentes com forte credibilidade junto às empresas contribui para o desenvolvimento desse tipo de confiança.

Além de grande relevância para temas de pesquisas, os autores como Sako (1998), Barney e Hansen (1994), Dyer e Chu (2003), entre outros, são objetivos ao afirmarem que a confiança em cooperação interorganizacional também pode ser uma fonte de melhor performance competitiva para as organizações. Explica-se: porque a confiança e a comunicação mais intensa entre as sociedades cooperativas, possibilitadas pela cooperação interorganizacional em rede, principalmente nas etapas de processamento e na distribuição, podem melhorar a competitividade dessas organizações.

Sobre a temática, os autores Koza e Lewin (1998) ensinam que o comportamento cooperativo está imbricado na história das firmas e na sua intercooperação. Ele é, sem dúvida, uma estratégia competitiva utilizada pelas empresas, na busca de vantagens competitivas e uma tendência que favorece muito os agentes na busca de sustentabilidade e competitividade no ambiente econômico. Essas relações de cooperação acompanham a própria história de suas organizações, pois este tipo de relacionamento está presente nos princípios do cooperativismo, de acordo com SILVA et alii (2004, p.10). Aos valores morais, pois, está associada a cultura de cooperação recíproca.

Nesse contexto, Slack et alii (1998) ressalta a necessidade e a importância de parcerias verdadeiras, sendo primordial um elevado grau de confiança entre os parceiros. Isso implicará coordenação de tarefas organizacionais, dispensando instrumentos burocráticos de controle e monitoração. Essa ótica é corroborada por Fusco (2004), quando salienta a importância econômica do aspecto da confiança nas transações, principalmente, nas vantagens logísticas.

Inúmeros entraves negociais podem ser solucionados mediante a utilização de técnicas societárias e/ou contratuais, como por exemplo, os negócios a serem realizados pelas sociedades cooperativas que têm como consequência direta na gestão dos ganhos, decorrentes dessas operações. Há situações em que o ativo a ser cedido só adquire atratividade em virtude da estrutura da operação sugerida. Incontáveis transações deixam de ser efetivadas em 
decorrência da estrutura de operação negociada pelas partes não ser capaz de compor os seus interesses pela falta de confiança. Isso pode ser evitado por estudos que demonstrem as opções de estruturação dos negócios, e que sejam de pleno conhecimento das partes.

Pesquisando os resultados que as firmas obtiveram através da participação em redes interorganizacionais, Human e Provan (1997) encontraram benefícios (econômicos e não econômicos) em quatro categorias de resultados:

(1) transação interorganizacional, com benefícios que são obtidos através de transações diretas e trocas entre as firmas da rede, em quatro grupos: negócios, informação, amizade ou relacionamentos pessoais e competências (habilidades), por exemplo, em compras e vendas, produção, serviços e marketing em conjunto, compartilhamento de informações e de boas ideias; (2) credibilidade interorganizacional: que se refere à percepção de que externamente a legitimidade da firma foi melhorada, pois incrementou a visibilidade e a credibilidade dos membros da rede;

(3) acesso a recursos: onde os benefícios são obtidos através de acesso a novos mercados, criação de novas ideias para novos produtos e processos, e outros recursos valiosos para as firmas, como tornar-se um cliente e/ou um fornecedor para as firmas membros da rede, entre outros;

(4) melhor performance financeira, com benefícios econômicos, como aumento de vendas e de rentabilidade, a confiança e o comprometimento que estão embutidos no pensamento da rede (HUMAN e PROVAN, 1997, p. 368, 403).

Inclui-se nessas categorias, a estratégia da intercooperação de sociedade cooperativa de produção agropecuária. Segundo Silva et alii (2004), essa espécie está associada à cultura de cooperação recíproca para a busca de sustentabilidade e competitividade no ambiente econômico e, devido à importância econômica e social das sociedades cooperativas no agronegócio brasileiro, a estratégia de intercooperação em redes poderia resultar no crescimento e na sobrevivência dessas organizações, frente a um ambiente extremamente competitivo.

É nesse contexto que se podem incluir na temática "confiança", por exemplo, o instituto da cessão de bens e direitos pela sociedade cooperativa de produção para outra organização, como alternativa de criação beneficente de um escopo mais amplo, firmando coalizões sob a modalidade good will trust, permitindo à organização o aumento da eficiência em capitalização e captação de recursos. Para Almeida (2009), a transferência de bens a um 
administrador, por um determinado período de tempo, em certas condições, para que o patrimônio seja gerido e reverta em favor de um beneficiário, é uma forma de confiança.

Ainda em relação ao sentimento de pertença, deve-se dizer que ele ocorre quando a pessoa natural se identifica com a organização e sente-se parte dela. $\mathrm{O}$ individuo consegue interagir com o grupo, após sentir-se aceito. Nesta fase, cada um aprende a se aceitar e a ser, cada vez mais, ele mesmo, oferecendo aos demais os recursos únicos de que dispõem. Num trabalho de execução de tarefas, seus pontos de vista, ainda que diferentes, são acolhidos pelo grupo com possibilidade de complementaridade e de interdependência na solução de problemas que devem ser resolvidos pela equipe (MAILHIOT, 1973).

O comprometimento de um cooperado com a organização cooperativa em que atua é uma atitude particularmente importante para os negócios, em vista de suas associações com outras atitudes, como a forma de produção agropecuária, a satisfação com o vínculo e com comportamentos dos indivíduos que influenciam a organização, como o desempenho em tarefas e a rotatividade voluntária (COOPER-HAMIK; VISWESVARAN, 2005; MEYER, 2009; MATHIEU; ZAJAC, 1990). Há, na literatura, diferentes definições para o instituto (MOWDAY; STEERS; PORTER, 1979; ALLEN; MEYER, 1990), sendo que todas compartilham a ideia de que o comprometimento organizacional, envolve formas múltiplas de ligação da pessoa com a empresa. Uma das formas desse comprometimento é visível no arranjo institucional, realizado com o cooperado e a sociedade cooperativa.

Pela relevância temática acima, é importante correlacionar o estudo sobre o desempenho das cooperativas não agrícolas nos EUA, com Bhuyan e Leistritz (2001), onde se encontra evidências de que o comprometimento dos membros é fundamental para o sucesso da sociedade cooperativa, pois a lealdade e a participação dos membros de qualquer organização member based é um ponto crítico para a sua sobrevivência.

E, ainda, a partir de uma amostra de associados de cooperativas no meio atlântico dos EUA, Bhuyan (2007) conclui que existe forte correlação entre o comprometimento de um associado e a sua satisfação quanto à gestão da cooperativa. De acordo com o autor, quanto menor for a 
atenção dada pelo gestor aos produtos e as preferências dos associados, maior a chance de insatisfação destes com relação à cooperativa e, portanto, menor será sua lealdade.

Boa parte dos debates e das pesquisas de campo sobre a matéria tem como premissa conceitual a distinção entre três bases de comprometimento (ALLEN; MEYER, 1990), a saber:

1) a base afetiva, que envolve a vinculação do indivíduo com a empresa em função de fatores emocionais, da aceitação e internalização pelos indivíduos de objetivos e valores organizacionais, e do seu desejo de fazer esforços em nome da organização;

2) a base normativa, que envolve a vinculação do indivíduo à empresa em função da crença por parte do funcionário de que este é o seu dever ou sua obrigação moral como retribuição à organização pelo emprego; e

3) a base calculativa, que envolve a vinculação do funcionário com a empresa em função de ganhos pessoais conexos à manutenção do emprego atual, e da ausência de alternativas de emprego.

Alguns autores sugerem que a dimensão calculativa na verdade deveria ser tratada como duas bases distintas, já que a continuação de uma associação para evitar o sacrifício de investimentos já realizados na organização é substantivamente distinta da continuação devido à escassez de alternativas ao emprego atual (BLAU, 2003; MEYER et alii - 2002). Contudo, de maneira geral, pode-se dizer que indivíduos comprometidos por razões afetivas, normativas ou calculativas se mantêm ligados à empresa, respectivamente, porque assim querem, devem ou precisam permanecer (ALLEN; MEYER, 1990).

É possível observar nas sociedades cooperativas pesquisadas que, quando um cooperado possui o comprometimento afetivo, é motivado pelo desejo de permanecer na organização, de "fazer parte" do negócio e se comportar de modo que os outros também são influenciados por esse desejo e, automaticamente, transforma o ambiente para a geração de valor. Em se tratando de uma sociedade cooperativa de produção agropecuária, é muito importante registrar que esse pertencimento ocorre de forma mais evidente, principalmente, devido à própria natureza das atividades desenvolvidas pelos cooperados.

Os benefícios advindos da presença do componente instrumental do comprometimento é de 
fácil observância nas sociedades cooperativas. O cooperado decide permanecer na organização, quando motivado pela necessidade de ocorrência de ganho de escala e de aprendizagem, ou por acreditar que os custos de sua saída são elevados para a sociedade cooperativa. Essa permanência pode ser vista como algo positivo, se levar em conta que, nesse tipo de empreendimento, independente das mudanças no mercado, poderá haver a garantia de um meio de subsistência e melhoria de bem-estar.

Outro aspecto a ser observado, é a segurança da estabilidade, pois numa gestão cooperativa, na grande maioria das vezes, as exclusões dos cooperados ocorrem por iniciativa própria e o conselho só interfere em casos de extrema necessidade, como negligência, indisciplina, descumprimento dos princípios, entre outros. Desse modo, pode-se afirmar que a necessidade de permanecer tem levado os membros a pensarem na organização como uma garantia da produção, industrialização e comercialização da produção agropecuária do cooperado.

Também é imprescindível na organização o comprometimento normativo. É a possibilidade de que as normas e valores da organização sejam partilhados pelos cooperados e sociedade cooperativa. Nesse sentido, os cooperados internalizam essas normas e valores e moldam seu comportamento com base nelas, favorecendo assim a organização. Ao agir em conformidade com os valores da cooperativa, as experiências originadas dessas ações promovem um sentimento de dívida e uma necessidade de retribuir os benefícios adquiridos.

De acordo com Hansmann (1996), a maioria dos cooperados de uma sociedade cooperativa tem parte significativa da sua renda dependente dos resultados obtidos pela organização. Os resultados da sociedade cooperativa afetam a renda dos seus cooperados porque estes se apropriam do excedente gerado pela sociedade cooperativa, por meio da aquisição ou venda de produtos ou serviços por um preço mais favorável. Ademais, a renda do cooperado é melhorada porque a sociedade cooperativa proporciona assistências e outros benefícios que se apresentam como quase renda, além de se apropriarem do excedente gerado pela sociedade cooperativa por meio da divisão das receitas residuais obtidas na atividade operacional. 
Se, por um lado, essa relação entre a renda do cooperado e os resultados obtidos pela sociedade cooperativa geram fortes incentivos para que seus cooperados tenham maior interesse no processo de tomada de decisão coletiva, seja revelando suas preferências, seja monitorando o comportamento do gestor e de outros membros dos órgãos de administração, por outro lado, esta dependência torna os cooperados mais avessos ao risco, já que boa parte da sua renda pode ser comprometida, pressionando o seu gestor a adotar estratégias mais conservadoras.

Seja qual for a razão para permanecer, quanto maior o comprometimento dos membros com a organização melhores resultados serão obtidos por todos os envolvidos e pela própria organização cooperativa, que poderá ter nesse comprometimento uma vantagem competitiva e desenvolver-se de maneira sustentável no mercado no qual está inserida.

São muitos os fatores que podem influenciar a visão do cooperado sobre a sociedade cooperativa, como a história dessa organização, o tipo de gestão exercida por seus diretores e, também, o interesse e participação dos cooperados. Porém, o que se observa é que existe uma forte relação de dependência que constrói uma relação dicotômica entre o bem individual e o coletivo, e sobre o valor da cooperativa para o cooperado.

Portanto, a confiança, o orgulho e pertencimento são atributos essenciais aos cooperados, e, quando utilizados, podem gerar ganho intangível, principalmente por influenciar no comportamento das sociedades cooperativas, no sentido de propiciar maior otimismo, motivação e comprometimento durante o processo e desenvolvimento da cooperação, gerando expectativas positivas para que os cooperados enfrentem os desafios futuros. 


\section{O COOPERADO PESSOA FÍSICA E A TEORIA DA RENDA}

\subsection{A RENDA DO COOPERADO PESSOA FÍSICA PRODUTOR RURAL}

O desenvolvimento econômico decorre do crescimento da economia, que deve ser acompanhado de um processo de geração e distribuição de renda para a população, da forma mais igualitária possível. Não se pode entender por desenvolvimento econômico a situação em que há crescimento da renda nacional, acompanhada por forte concentração de resultados apropriáveis por poucas pessoas.

A sociedade procura caminhos capazes de lhe conferir condições básicas de inserção nas estruturas de produção e geração de renda. Uma das formas adotadas para isso tem sido por meio da organização econômica, estruturada na forma de sociedade cooperativa que, evidentemente, não tem existência estanque (FRANKE,1973). A sociedade cooperativa tem como característica o contato direto com as demais organizações econômicas, podendo, inclusive, participar no controle societário (BRASIL, 1971).

As sociedades cooperativas se distinguem conceitualmente das organizações empresariais por um traço altamente característico: enquanto nas sociedades empresárias, a pessoa se associa para participar dos lucros sociais na proporção do capital investido; nas sociedades cooperativas, a razão que conduz o ingresso do cooperado não é a obtenção de lucros ou dividendos, ou seja, inexistência de escopo de lucro, sendo que o pagamento das sobras líquidas do exercício ocorre proporcionalmente às operações realizadas pelos cooperados. Contudo, existe a possibilidade de utilizar-se dos serviços dessas sociedades para melhorar as condições econômicas e sociais, inclusive com o processo contínuo de ganhos indiretos. Por isso, impõe-se que o cooperado pessoa física seja, ao mesmo tempo, o usuário ou cliente e participe ativamente das atividades negociais.

A sociedade cooperativa de produção agropecuária, ao realizar operações decorrentes do ato cooperativo, tem como primazia a produção agropecuária oriunda do cooperado destinada à própria organização. Os produtos, desde a forma in natura ou após transformados ou industrializados, necessitam para total execução, de outro negócio, que consiste na 
comercialização pela sociedade cooperativa no mercado interno ou externo, com reversão do respectivo preço, minus custos ou despesas, ao cooperado.

A forma sui generis trazida pelo modelo societário e a operacionalidade do ato cooperativo são fatores decisivos para o ingresso dos cooperados, desde que estes desejam utilizar-se dos serviços prestados pela sociedade cooperativa e ainda, adiram aos propósitos sociais, preenchendo as condições estabelecidas no estatuto social. É imperioso que os cooperados tenham pleno conhecimento de que a sociedade cooperativa é uma organização de pessoas, com forma e natureza jurídica próprias, constituída com a finalidade de prestar serviços.

É nesse contexto, que se pretende, a partir da linha teórica conceitual de renda, contribuir para o estudo do ganho indireto, decorrente da melhoria socioeconômica dos cooperados, durante determinado período de tempo, e precisar como os cooperados percebem as diferentes categorias de benefícios econômicos que são proporcionados pela sociedade cooperativa de produção agropecuária.

\subsection{A RENDA AUFERIDA PELO COOPERADO}

\subsubsection{Teoria da renda e sua mensuração}

O cooperado pessoa física, ao participar de uma sociedade cooperativa de produção agropecuária, tem como expectativa auferir ganhos: o ganho direto, seja pelo aumento de rendimentos e receitas, seja pela redução de custos e despesas, aliado ao aumento de produção, que pode decorrer da industrialização e comercialização dos produtos agropecuários traduzidos monetariamente; e o ganho indireto, que consiste na melhoria econômica, configurada pelo desenvolvimento de várias atividades realizadas pela sociedade cooperativa de produção agropecuária em prol dos cooperados, como a assistência técnica e profissional, a extensão rural, decorrentes de serviços prestados em benefício comum, ou seja, com foco em negócios agropecuários desenvolvidos pela organização. 
Perceber como ocorre o ganho indireto é o ponto central da tese, que vai exigir, de forma objetiva, uma fundamentação teórica e, ainda, que os fatos analisados contemplem o problema da pesquisa científica.

As teorias que fundamentam a mensuração da renda auferida por pessoa física têm sido muito utilizadas para fins tributários, a começar pela renda medida como bem-estar (GASSNER, 2005). Para Holmes (2001), mensurar com precisão o grau de bem-estar individual é tarefa notadamente difícil, já que isso depende de fatores que não comportam uma exata quantificação, como, por exemplo, a felicidade ou a adequação da situação do indivíduo ao estilo de vida desejado.

A conceituação de bem-estar contém em si um debate caloroso, que acresce dificuldades em alcançar um consenso em torno de sua definição, uma vez que, em última instância, cada indivíduo como produtor rural possui uma concepção própria do que venha a ser bem-estar. Dessa forma, mesmo ante tais obstáculos na mensuração do bem-estar, deve-se buscar alguma forma de sua percepção, considerando sempre a premissa de que a renda refletida pelo bemestar pode ser o parâmetro de uma qualificação mais justa, inclusive para fins de diferenciação dos produtores agropecuários pertencentes ao quadro societário das sociedades cooperativas de produção agropecuárias e agroindustriais.

Holmes (2001) adverte que, sob o ângulo do consumo de bens e serviços, o ganho indireto denotaria determinado nível de bem-estar. Simplesmente, o aumento do consumo individual poderia refletir acréscimo no grau de felicidade e prazer do indivíduo e, portanto, no aumento do bem-estar. O consumo de bens e serviços é perfeitamente mensurável, no entanto, não é consenso entre os estudiosos que seja medida adequada para avaliar o bem-estar. A utilização do consumo de bens e serviços, como medida de bem-estar, ignora outras razões de cunho psicológico que podem influenciar na percepção de maior ou menor renda e, por conseguinte, em maior ou menor grau de consumo.

Em continuidade a essa linha teórica, percebe-se que Gassner (2005) chega à mesma conclusão quando aponta várias dificuldades decorrentes da indefinição do conceito de bemestar. O bem-estar ou a renda psicológica, como condição para a tributação e a renda, como substituta da capacidade de pagamento, é algo excessivamente vago para se tornar operacional em um processo legislativo. Os economistas definem a renda pela finalidade e explicam os 
fundamentos da teoria da renda, por exemplo, para investigar os gastos das famílias ou analisar os efeitos da tributação na distribuição de renda e riqueza.

Sem ignorar as dificuldades na conceituação e definição de bem-estar, Holmes (2001) aduz que o bem-estar dos cidadãos numa sociedade é necessariamente integrado pela equidade na distribuição dos recursos materiais e imateriais. Dessa forma, este autor conclui que a renda é a medida mais utilizada para, de forma pragmática, medir o bem-estar do indivíduo. Da mesma forma, se o bem-estar for utilizado como medida diretiva de uma condição econômica mais justa, isso conduz à conclusão de que a renda do indivíduo é a medida que melhor substitui, em termos mensuráveis, o bem-estar.

O conceito fundamental de renda passa a ser necessário na investigação do estudo de caso porque os ganhos indiretos considerados são abstratos, podendo ser definidos como renda, por expressar uma condição também de bem-estar dos cooperados ao longo das atividades negociais com a sociedade cooperativa de produção agropecuária. Ressalte-se que os cooperados podem melhorar as condições de bem-estar quando auxiliados na área de conhecimento específicos para a exploração da atividade rural, momento em que apenas percebem a melhoria, sem, no entanto, poder quantificá-la.

Na expressão utilizada por Holmes (2001), a renda é caracterizada como acréscimo monetário de riqueza, mais a renda imputada e os gastos com bens e serviços consumidos em determinado período de tempo. Tal conceito se baseia no modelo denominado Schanz ${ }^{12}$ Haig ${ }^{13}$-Simons, ${ }^{14}$ doravante Modelo SHS. ${ }^{15}$ Tem-se, portanto, um tripé que suporta o conceito fundamental de renda defendido pelo filósofo neozelandês: a renda é composta por: (i) acréscimo monetário de riqueza; (ii) renda imputada; e (iii) gastos com bens e serviços. Para melhor entender o Modelo SHS, ou o conceito fundamental de renda, torna-se necessário verificar os fundamentos da definição, nos tópicos seguintes deste capítulo, base para construção teórica dos autores.

\footnotetext{
${ }^{12}$ Fluxo de riqueza ao longo do período de tempo (HOLMES, 2001, p. 57-8).

${ }^{13}$ Fluxo do dinheiro dos serviços ou mercadorias utilizadas durante um determinado período ou (...) o próprio dinheiro recebido durante o período de tais bens e serviços, sem uma transação monetária (HOLMES, 2001, p. $71 ;$ p. 59-66).

${ }^{14}$ Molda sua formulação em termos do valor dos direitos de propriedade detidos por uma pessoa, ou seja, a capacidade para controlar recursos e, por isso, para exercer o poder econômico (HOLMES, 2001, p. 71; p. 66-8).

${ }^{15}$ Observado em Holmes (2001, p. 69-70).
} 
Portanto, o cooperado pessoa física, ao auferir os ganhos indiretos, originários de diversas formas colocados à disposição pela sociedade cooperativa de produção agropecuária, pode evidenciar tratar-se de renda sem quantificá-la, seja pela condição de bem-estar, seja pelo acréscimo monetário de riqueza, seja pelos gastos com bens e serviços; e essa percepção de ganho deve ser investigada no estudo de caso.

4.2.1.1 Renda psicológica - gastos com bens e serviços

De acordo com a assertiva de Seligman (1926 apud HOLMES, 2001, p. 36-7):

(...) a renda como medida de riqueza é fundamentalmente psicológica bem como histórica. Nós fazemos as coisas em última instância em busca do sentimento de bem-estar. Só se pode entender esta utilidade na forma da sucessão de sensações prazerosas. Estas sensações são a verdadeira renda. (...) O conceito originário de renda é, portanto, a renda prazer ou a renda benefício.

Parece claro, portanto, que a renda psicológica consiste na sensação de satisfação obtida pela pessoa física em decorrência da utilização de determinados fluxos não financeiros percebidos, ou seja, um fluxo de sentimentos de satisfação decorrente de experiências psicológicas intangíveis.

Holmes (2001) ressalta que, antes de adentrar nas críticas quanto à mensuração da renda psicológica, é necessário distinguir a renda recebida (inflow) da renda gasta (outflow). A visão que se obtém da análise dos recursos recebidos pelo indivíduo é bastante diversa daquela que tem por objeto o fluxo de recursos destinados ao consumo de bens e serviços. Explica-se. O bem-estar seria decorrente do consumo, que é representado por uma saída de recursos (outflow). A renda percebida (inflow) é uma medida tomada em momento anterior à equação renda - consumo - bem-estar (ou renda psicológica) e, portanto, menos adequada para refletir a renda psicológica. Parece também contestável, que a renda consumida constituir-se-ia como a melhor medida de bem-estar em comparação com a renda percebida. A renda percebida pode ser consumida ou poupada, sendo que a renda poupada será futuramente consumida na compra de bens e serviços. Assim, renda percebida é renda consumida, mais renda poupada, que se transformará futuramente em consumo. 
Logo, não se deve desconsiderar a sensação de bem-estar decorrente da renda poupada. A pessoa opta por poupar para futuramente, ou mesmo para ter maior segurança quanto às futuras necessidades. A própria renda poupada traz sensação de bem-estar, adequando-se, nesse aspecto, ao conceito de renda psicológica.

\subsubsection{Acréscimo monetário de riqueza}

Como já foi explicitado, o conceito fundamental de renda, baseado no sistema SHS, possui um segundo pilar. Considera-se renda o acréscimo patrimonial, mesmo que não realizado.

Segundo o modelo, constitui-se renda "o aumento ou acréscimo do poder do indivíduo de satisfazer suas vontades num determinado período, sendo que este poder consiste em: dinheiro propriamente dito ou qualquer coisa susceptível de ser avaliada em dinheiro" HOLMES (2001, p. 71).

Dessa forma, os ganhos não realizados passíveis de ser avaliados em dinheiro constituem-se, na opinião do autor, em renda, já que possibilitariam ao indivíduo satisfazer as vontades, aumentando assim a sensação de bem-estar.

Por sua vez, o acréscimo patrimonial não realizado não aumenta diretamente a capacidade do indivíduo em satisfazer as vontades, já que é aumento de patrimônio que não é convertido em dinheiro neste momento e, portanto, não pode ser utilizado no consumo de bens e serviços. Em contrapartida, parece inegável que o aumento do valor de um bem possuído pela pessoa física gera sentimento de satisfação, sensação de bem-estar. Tal satisfação é diversa daquela gerada pelo consumo, pois ela não traz sentimento de bem-estar imediato.

A noção de acréscimo patrimonial decorre dos estudos desenvolvidos por Roberto M. Haig, posteriormente incorporados pelo sistema SHS, em que o "H" remete à letra inicial do nome do autor: Haig (1921). Conforme Holmes (2001), numa viagem de férias, com a mesma renda de 100 unidades decorrente da valorização da residência de uma mesma pessoa física, parece ser inegável que a satisfação decorrente da renda monetizada é maior do que aquela renda gerada pelo acréscimo patrimonial não realizado. No entanto, ambas geram, em medidas diversas, sensação de bem-estar. 
Por conseguinte, o bem-estar percebido pelo acréscimo patrimonial não realizado assemelhase àquele advindo da renda poupada, já que ambos poderão, futuramente, ser utilizados no consumo de bens e serviços.

\subsubsection{Renda imputada}

Para Holmes (2001), a terceira questão que constitui o tripé do Modelo SHS refere-se à consideração como renda do benefício decorrente da utilização dos bens próprios da pessoa física. O conceito de renda é relacionado ao aumento do poder econômico do indivíduo, assim, devem-se verificar quais meios compõem esse poder econômico em determinado período de tempo.

O acréscimo do poder econômico não é só representado pelo aumento dos bens materiais, mas inclui aqueles meios que geram sensação de bem-estar. Como forma de mensuração prática do acréscimo de poder econômico, o Modelo SHS, trazido por Holmes (2001), sugere a consideração como renda do benefício advindo da utilização de bens próprios.

A pessoa física, ao utilizar um bem de sua propriedade, obtém sentimento de satisfação, de bem-estar. Em termos ainda teóricos, é necessário questionar quais benefícios decorrentes da utilização de bens próprios deveriam ser considerados como renda. A mensuração da renda imputada em decorrência da utilização da casa própria é de fácil compreensão. No entanto, o mesmo não ocorre com outros benefícios percebidos pela pessoa física rural, como, por exemplo, o bem-estar de cultivar as próprias verduras ou frutas na propriedade rural, com o conhecimento adquirido por intermédio da cooperação.

A consideração da renda imputada, no conceito fundamental de renda, atende aos preceitos da equidade horizontal, visto que atribui o mesmo tratamento a pessoas físicas em situação equivalente, ou seja, é a possibilidade de atribuir o mesmo nível de renda quando elas se encontram em nível de equivalência, seja financeira, seja patrimonial.

Portanto, a partir das observações dessa linha teórica da renda, é possível afirmar que o ganho indireto constitui renda para o cooperado, e o modelo trazido por Holmes (2001) pode ser útil para qualificar a melhoria econômica percebida pelo cooperado pessoa física, decorrente do 
desenvolvimento de várias atividades realizadas pela sociedade cooperativa de produção agropecuária, como assistência técnico-profissional e extensão rural, justificando-se assim o modelo de mensuração com a aplicação do método, de acordo com a natureza de cada ganho.

\subsection{GERAÇÃO DE VALOR ECONÔMICO PARA O COOPERADO PESSOA FÍSICA}

É inegável o desejo das pessoas de melhorar a condição de vida. Para Nascimento (2000), esse desejo corresponde ao comportamento racional, que deve juntar-se ao comportamento solidário para que, simultaneamente, sejam alcançados objetivos, como redistribuição de renda, melhoria dos mercados e do bem-estar individual, pela prática democrática. Trata-se de eficiência econômica no uso dos recursos, quando se assume uma consistência de comportamento dos agentes econômicos na tomada de decisões. Assim, a integração via sociedade cooperativa dos cooperados, antes à margem dos processos operativos, é traduzida pela possibilidade de distribuição mais justa da renda gerada, em consonância com a eficiência econômica e os princípios do cooperativismo.

Nesse contexto, o Fates constitui a fonte originária de recursos da retenção de sobras líquidas, indivisível (não distribuível aos cooperados), que será utilizada para propósitos específicos: prestação de assistência aos associados e familiares e, quando previsto no estatuto da cooperativa, aos empregados dela. Esse fundo, quando aplicado, sinaliza a verdadeira expressão econômica de um princípio cooperativo: o investimento na educação do cooperado. Educação necessária para a formação do patrimônio comum, destinado a promover o crescimento pessoal e social dos cooperados e familiares, facultando a extensão da utilização da finalidade aos empregados.

A sociedade cooperativa de produção agropecuária ao utilizar o valor da Fates, sob as mais variadas formas, pode oferecer ganho indireto ao cooperado e constituir fonte de renda de difícil mensuração, que atinge estágios importantes, podendo trazer, como consequência, redução ou eliminação das imperfeições de mercado e maior eficiência econômica.

Nesse sentido, a partir da linha teórica conceitual de renda é possível contribuir para a existência do ganho indireto, pela melhoria socioeconômica dos cooperados durante 
determinado período de tempo. A renda pode ter origem no desenvolvimento de várias atividades operacionais realizadas pela sociedade cooperativa de produção agropecuária, e a destinação da parcela para formação do Fates contribui para os gastos com assistência técnica e profissional, extensão rural e aqueles decorrentes de serviços prestados em benefício comum dos cooperados.

De outra parte, a renda, classificada de ganho direto, pode decorrer do investimento feito pelo cooperado, quando da aquisição da quota-parte de capital social pelo resultado positivo da atividade operacional (sobras líquidas) ou da entrega da produção agropecuária à sociedade cooperativa. Assaf Neto (2009) assevera que o investimento de um cooperado revela atratividade econômica somente quando a remuneração oferecida for suficiente para remunerar o custo de oportunidade do capital próprio aplicado na atividade. E, ainda, o autor revela que o valor econômico é criado ao cooperado somente quando as receitas operacionais superarem todos os dispêndios (custos e despesas) incorridos, inclusive o custo de oportunidade do capital próprio. Ressalte-se, todavia, que a sociedade cooperativa de produção agropecuária não tem por finalidade o lucro. Entretanto, quando resultado positivo é apurado, ele é indivisível (não distribuível aos cooperados), devendo ser destinado a propósitos específicos, integrando o valor do Fates, considerado fonte necessária de recursos para proporcionar as melhores condições de financiamento dos ganhos indiretos aos cooperados.

Portanto, abstraindo a geração de valor econômico-financeiro aos cooperados, resultante da atividade operacional da sociedade cooperativa, a remuneração da quota-parte do cooperado não deve ser considerada um ganho indireto. Este somente é percebido pelos cooperados quando da melhoria do bem-estar, trazida pelos benefícios econômicos decorrentes do desenvolvimento de várias atividades, realizadas pela sociedade cooperativa de produção agropecuária, como a assistência técnico-profissional, extensão rural, entre outras. 


\section{ASPECTOS METODOLÓGICOS}

A presente pesquisa é exploratória, realizada em área com pouco conhecimento acumulado e sistematizado, com abordagem qualitativa por meio estratégico de estudo de caso. Então, a abordagem qualitativa envolve entrevistas, observações e questionários, que não resultam em dados quantitativos, mas em descrições dos resultados e nas impressões dos eventos.

Por meio das entrevistas com técnicos especializados, permite-se extrair dados qualitativos das sociedades cooperativas de produção agropecuárias, inclusive, as agroindustriais localizadas no Estado do Rio Grande do Sul, para esclarecer e servir de subsídios na elaboração dessa tese científica. As entrevistas são importantes para auxiliar nas respostas às questões de pesquisas.

Com esse tipo de abordagem, foi possível explorar relações que não poderiam ter sido feitas de outra forma. A maior limitação é a impossibilidade de generalizações dos resultados para populações maiores ou para situações mais gerais. Normalmente, não é possível incluir amostras representativas devido a problemas práticos de escala e à natureza das observações e das situações estudadas (BLACK, 1999).

Dessa forma, depois de analisar a capacidade das sociedades cooperativas de gerar o resultado econômico e financeiro, procuraram-se os especialistas dessas organizações para obtenção dos dados relevantes como os cooperados, ambos na forma de entrevistas, para ser examinados e utilizados para as análises de sustentação e resposta ao problema de pesquisa. As sociedades cooperativas selecionadas terão as particularidades descritas a seguir.

\subsection{SOCIEDADE COOPERATIVA AGROINDUSTRIAL “A”}

A primeira sociedade cooperativa, com 10.465 cooperados e 500 funcionários, possui sede no leste do Rio Grande do Sul, doravante denominada de Sociedade Cooperativa Agroindustrial “A”. É uma cooperativa que recebe os produtos agrícolas e animais dos cooperados destinados à industrialização, para posterior comercialização no mercado interno e externo. 


\subsection{SOCIEDADE COOPERATIVA AGROINDUSTRIAL "B"}

Foi fundada por um grupo de 27 agricultores gaúchos reunidos em busca da sustentabilidade da lavoura e preocupados com a preservação do meio ambiente. A filosofia e atuação estratégica conquistaram mais de 32.000 produtores rurais cooperados, com unidades de negócios que atravessaram as fronteiras do estado do Rio Grande do Sul, possuindo 40 filiais, cuja linha de produção agrícola contempla a cultura de soja, arroz, milho, trigo, feijão, sorgo, cebola, alho, entre outras.

\subsection{SOCIEDADE COOPERATIVA AGROINDUSTRIAL "C"}

Localizada no centro do Estado do Rio Grande do Sul, tem atividades com abrangência estadual. O arroz beneficiado, que corresponde a 100\% da produção recebida dos cooperados, e a soja in natura são os principais produtos destinados ao mercado interno e externo. A posição de destaque que ocupa em âmbito nacional há mais de três décadas foi possível graças à constante modernização do parque de armazenamento e industrialização, alta tecnologia de suas unidades e rigorosos padrões exigidos nos processos de produção. Possui unidades de armazenamento e comercialização de produtos agrícolas, assistência técnica agronômica e veterinária, fornecimento de insumos agrícolas, além de lojas, supermercados e unidade de transportes.

\subsection{SOCIEDADE COOPERATIVA AGROINDUSTRIAL "D”}

A história desta sociedade cooperativa inicia-se, em 1875, com a chegada de imigrantes oriundos do norte da Itália. Estabelecidos no Sul do Brasil, numa localidade próxima à cidade de Porto Alegre, onde encontraram paisagem e clima similares aos do país de origem. Assim, os hábitos e a cultura europeia não foram abandonados, e a antiga arte da vitivinicultura logo foi retomada. 
No ano de 1931, dezesseis famílias de produtores de uvas reuniram-se para lançar a pedra fundamental do que viria a transformar-se no maior empreendimento do gênero no Brasil: uma sociedade cooperativa agroindustrial de produção de vinhos e derivados. Um ano mais tarde, já contabilizava a produção coletiva de 317.000 quilos de uvas e fixava a base de um empreendimento destinado a ser não apenas o maior produtor, mas também um dos mais qualificados tecnologicamente.

\subsection{ESTUDO DE CASO}

O estudo de caso é uma pesquisa empírica, que investiga um fenômeno contemporâneo dentro do contexto real, onde as fronteiras entre o fenômeno e o contexto não são claramente evidentes e nas quais múltiplas fontes de evidências são utilizadas. A opção pelo estudo de caso surge do desejo de compreender um fenômeno social complexo e permite preservar as características holísticas e significativas dos eventos da vida real (YIN, 2010).

Apesar de não proporcionar bases para generalizações, o estudo de caso permite reunir grande número de informações, com bom grau de detalhamento, o que facilitará a melhor compreensão do fenômeno investigado.

Mais especificamente, trata-se de um estudo de casos múltiplos para investigação empírica contemporânea de fatos qualitativos, que se apresentam claramente evidentes e devem seguir um conjunto de procedimentos pré-especificados, que será usado para entender um fenômeno real com profundidade. A opção pelo método do estudo de caso deve-se ao fato de permitir esse entendimento de um fenômeno da vida real em profundidade. Inclui-se tanto o estudo de caso único quanto o de casos múltiplos. Aquele é um projeto apropriado sob várias circunstâncias e análogo ao experimento único, e muitas das mesmas condições que justificam um único experimento, igualmente podem justificar uma estrutura de caso único; estes se justificam para projetos de casos múltiplos e derivam, diretamente, do entendimento das replicações literais e teóricas. A existência de ganhos econômico-sociais indiretos dos cooperados requer que a investigação seja de estudo de casos múltiplos, porque se concentra no como e no porquê os resultados exemplares podem ter ocorrido e no objetivo de replicações literais dessas condições de caso para caso. 
A técnica de coleta dos dados necessários para o estudo de caso será a modalidade de entrevistas, por ser importante e essencial ao estudo de caso (YIN, 2010). Para o autor, as entrevistas são conversas guiadas e não investigações estruturadas, ou seja, embora observada uma linha de investigações consistentes, a verdadeira corrente de questões, na entrevista de estudo de caso, será provavelmente fluída, não rígida.

De acordo com Marpsat (2001 apud BRAGA, 2007, p. 16), "a diferença essencial entre métodos quantitativos e qualitativos está nas distintas maneiras de se ir da parte para o todo." Exatamente por isso, o entendimento moderno do problema é que quantitativo e qualitativo designam técnicas de análise de dados que, embora diferentes, podem ser combinadas para produzir respostas mais completas às questões. Logo, o que dá o caráter quantitativo ou qualitativo não é necessariamente o recurso de que se fará uso para a coleta de informações, mas o referencial teórico-metodológico utilizado para a análise do material coletado (DUARTE, 2004).

A mensuração do resultado, qualificado pelas sobras líquidas apuradas anualmente, é obtida das demonstrações financeiras obrigatórias, que consideram a geração de resultado o momento da comercialização dos produtos agropecuários. Essa sistemática não captura a geração de resultado econômico dos eventos antecedentes ao evento da venda. Estes eventos são tão importantes quanto aquele da venda, dentro do processo de criação de valor pela atividade econômica.

Conforme preconiza a boa teoria contábil, a geração de sobras líquidas acontece durante todo o processo - apontá-lo apenas no ato da venda decorre de uma convenção que facilita a confrontação entre receitas e despesas (e custos, que são acumulados a té o evento da venda). Conclui-se que a técnica de pesquisa social procura, a partir da interação formal entre o pesquisador e o técnico especializado da organização, produzir informações sobre a investigação que sejam capazes de precisar como a sociedade cooperativa de produção agropecuária gera resultado econômico e financeiro e como destina o valor da parcela para a constituição do Fates. 


\subsubsection{Seleção do Caso}

Segundo Eisenhardt (1989), em estudos de casos não se utiliza amostra estatística, mas, sim, amostras teóricas. O caso deve ser escolhido para replicar ou estender uma teoria emergente, como também para completar categorias teóricas. Para a autora, faz sentido que se escolha um caso em que o processo de interesse seja facilmente observável. Assim, o objetivo da amostra teórica é escolher um caso em que a teoria emergente possa ser replicada ou estendida.

O caso escolhido para o estudo sobre as sociedades cooperativas de produção agropecuária, inclusive, as industriais, se deve ao fato de o tema despertar interesse, nos seguintes aspectos:

a) são organizações regionais que procuram enfrentar os desafios com soluções econômicas e sociais direcionadas ao bem-estar dos cooperados, cujo objeto está relacionado com o ramo agropecuário, base para o desenvolvimento da região;

b) são associações populares e de empresa comum, que fornecem, a título oneroso, quota-parte equitativa de capital social ao cooperado e procuram retribuir, em contrapartida, diretamente, à justa participação nos riscos e nos frutos decorrentes de cada objeto e finalidade e, indiretamente, à economia da aprendizagem sob as mais variadas formas;

c) os contratos que regulam as transações negociais realizadas por essas organizações e seus cooperados procuram reduzir os riscos e as incertezas, nas operações notadamente caracterizadas pelo ato cooperativo;

d) identifica-se, na relação cooperado e sociedade cooperativa, o instituto da cooperação como estratégia empresarial, no estabelecimento de formas flexíveis de colaboração mútua mais vantajosa que os custos de renúncia a uma condição livre de mercado; e,

e) o fato de o tema pesquisado ser contemporâneo, apresentando empatia e interesse dos integrantes das organizações cooperativas, sobre matéria complexa que desperta curiosidade dos pesquisadores, comunidade científica em geral e demais entidades públicas e privadas. 


\subsubsection{Coleta de Dados}

Para a coleta de dados serão seguidos três princípios, conforme indicado por Yin (2010): 1) utilizar múltiplas fontes, evidências de duas ou mais fontes convergindo sobre os mesmos fatos ou descobertas (triangulação de dados); 2) criar uma base de dados, uma estrutura formal de evidência, distinta do relatório final do estudo de caso (que pode ser composta por notas, documentos, tabelas e narrativas); e 3) manter o encadeamento de evidências, vínculos explícitos entre as questões formuladas, os dados coletados e as conclusões a que se chegou.

As investigações para obtenção das informações relevantes são obtidas por meio das entrevistas semiestruturadas. O roteiro é caracterizado por uma série de perguntas abertas, feitas verbalmente numa ordem prevista, mas na qual o entrevistador pode acrescentar perguntas de esclarecimento (LAVILLE; DIONNE, 1999, p. 188). Há a entrevista aberta, que muito se assemelha ao descontraído bate-papo de que falava Mann (1983), sendo uma técnica bastante utilizada "quando o pesquisador deseja obter o maior número possível de informações sobre determinado tema, segundo a visão do entrevistado, e também para obter um maior detalhamento do assunto questão" (BONI; QUARESMA, 2005, p. 74).

O primeiro objetivo numa entrevista é estabelecer uma relação amigável com o respondente, existindo três fatores que ajudam a aumentar a receptividade do entrevistado:

a) o respondente deve acreditar que a experiência será agradável e satisfatória;

b) o respondente deve acreditar que responder a essas perguntas é uma coisa importante e que não estará dispersando o tempo dele; e

c) o respondente deve abandonar qualquer desconfiança que possa ter sobre sua participação. (COOPER 2003, p. 253)

Conduzem-se as entrevistas com algumas explicações sobre os objetivos do estudo, principalmente em como as informações colhidas serão utilizadas no processo de fortalecimento das organizações cooperativas.

Os entrevistados foram escolhidos por possuir conhecimentos técnicos especializados e por eles serem capazes de demonstrar que a sociedade cooperativa de produção agropecuária, inclusive, a agroindustrial, apura corretamente as reservas, sobras líquidas e lucro acumulado, durante o exercício financeiro, de acordo com a boa técnica contábil ao abrigo das normas 
societárias e técnica contábil especial. São profissionais bem informados e podem proporcionar insights importantes sobre essa matéria.

As entrevistas são feitas em profundidade (YIN, 2010), pois os respondentes-chave permitem que se conheçam os fatos de um assunto técnico específico, assim como as opiniões conclusivas sobre as formações das sobras líquidas e das reservas e, ainda, porque facilitam uma sondagem muito mais esclarecedora e eficiente. Por se tratar, também, de questões mais estruturadas, será utilizada a metodologia de levantamento formal, segundo YIN (2010, p. 63), por corresponder a uma parte relevante do estudo de caso, que deve produzir dados qualitativos necessários como fonte imprescindível de informações.

Embora os métodos de registro possam variar, neste estudo de caso, o pesquisador deve escrever as respostas recebidas, que são registradas à medida que são fornecidas, sob pena de ocorrer perda de informações relevantes. Ademais, podem ser produzidas por instrumentos especiais de entrevistas, para registrar as respostas.

Dessa maneira, o presente estudo é direcionado ao problema de pesquisa, no qual surgem questões de pesquisas emergentes e contextuais, perfeitamente adaptáveis aos dados e às mudanças que podem ocorrer na pesquisa. Assim, inicialmente analisa-se: como a sociedade cooperativa de produção agropecuária gera resultado econômico-financeiro, obtido pelas entrevistas realizadas com especialistas das sociedades cooperativas, encarregados de determinar os resultados - lucros ou sobras líquidas.

\subsection{QUESTÕES DE PESQUISAS}

Sampieri et alii (2006) ensinam que, além de definir os objetivos concretos das pesquisas, é conveniente formular, por meio de várias questões, o problema a ser estudado. Formulá-lo em forma de questões tem a vantagem de apresentá-lo de maneira direta, minimizando a distorção (CHRISTENSEN, 2000).

É na formulação da questão de pesquisa que se procura apresentar o problema na totalidade, com toda a riqueza e conteúdo. No enfoque qualitativo, as questões devem ser gerais, e pouco a pouco se tornam mais precisas, esclarecidas e delimitadas. Para Rojas (2001), é necessário 
estabelecer limites temporais e espaciais do estudo, sendo muito difícil que todos os aspectos sejam incluídos nas questões de pesquisas.

Dessa maneira, não é possível dar passo adiante numa pesquisa, se, depois de enunciar o problema que a originou, não houver uma explicação ou solução por meio de questões de pesquisas.

Nesse contexto, foram elaboradas questões de pesquisas necessárias para conhecer a capacidade das sociedades cooperativas a fim de que possam gerar resultados positivos no período e nos próximos anos, de forma gradual, segura e rentável, autossustentando as atividades operacionais.

Ainda nesse caso, evidenciam-se duas questões de pesquisas. Primeiro, a base são as sobras líquidas, apuradas anualmente, capaz de capturar os ganhos indiretos, sobre as quais se questiona qual é a parcela que deve ser destinada à constituição do Fates. Segundo, inexistindo sobras líquidas, qual é a sistemática de apuração de ganhos classificados como indiretos, que são transferidos aos cooperados.

Assim, há necessidade de investigação, principalmente por haver uma relação muita estreita entre a proposição do problema e uma revisão de literatura, permitindo evidenciar as principais questões de pesquisas, a seguir relacionadas na Figura 3, que são elaboradas com base nos raciocínios desenvolvidos, sem, contudo, o propósito de testá-las estatisticamente.

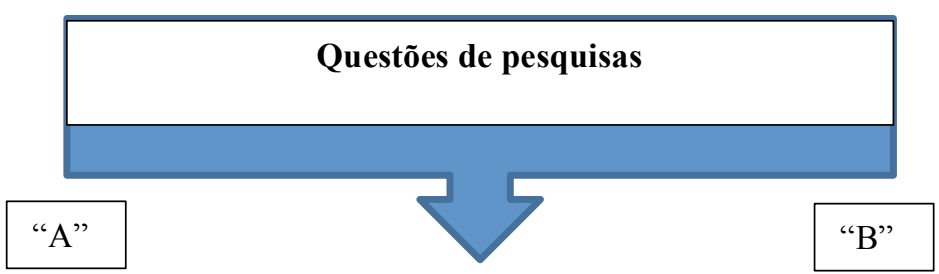

Se a sociedade cooperativa possui capacidade econômica e financeira para gerar anualmente resultado positivo, sob a forma de sobras líquidas, então deverá destinar aos cooperados, como ganhos indiretos, a parcela prevista no art. 28 da Lei $\mathrm{n}^{\mathrm{o}}$ 5.764, de 1971, para o Fundo de Assistência Técnica, Educacional e Social (FATES).
Se a sociedade cooperativa não possui capacidade econômica e financeira para gerar anualmente resultado positivo, sob a forma de sobras líquidas, e/ou não destina esse valor, então qual a sistemática de apuração de ganhos classificados como indiretos que são transferidos aos cooperados. 
Na questão de pesquisa "A", a sociedade cooperativa apura, anualmente, o resultado positivo em forma de sobras líquidas, ou mesmo realiza operação com não cooperado (ato não cooperativo); e o lucro decorrente apurado deve integrar o Fates, proporcionando condições para determinação dos ganhos indiretos, como suporte para atender à política de geração de renda aos cooperados.

$\mathrm{Na}$ questão de pesquisa " $\mathrm{B}$ ", a sociedade cooperativa não apura o resultado positivo anualmente em forma de sobras líquidas e não se evidencia contabilmente a formação do Fates. Mas percebe-se que esse valor integra os pagamentos realizados aos cooperados, decorrentes da comercialização dos produtos agropecuários por eles entregues. Neste caso, a investigação consiste em identificar qual a sistemática que a organização utiliza para fazer a transferência de ganhos indiretos aos cooperados.

Os dados relevantes coletados, na forma de entrevistas, são examinados e utilizados para as análises de sustentação e são fontes para construir outras questões de pesquisas. Observa-se que as questões de pesquisas construídas, apesar de provisórias, tornam-se em seguida o ponto de partida de um novo procedimento indutivo, em que se efetua um retorno à realidade para submeter essa explicação à prova dos fatos.

Por último, as entrevistas foram pessoais, e seu conteúdo e sequência constam no Apêndice 1. Elas foram previamente programadas, com o objetivo de reduzir despesas e tempo, como, por exemplo, a utilização de mensagens via e-mail ou ligações telefônicas para marcá-las antecipadamente. Entende-se que, nessa forma pessoal, haveria o estabelecimento de empatia e interesse pelo estudo, o que facilitava a sondagem das questões relevantes e complexas com grande quantidade de respostas. As questões foram específicas e cuidadosamente elaboradas, permitindo que os entrevistados fizessem os comentários importantes e atendessem aos objetivos pretendidos.

Por sua vez, pela ótica da teoria da renda, as proposições são construídas para verificar as transferências dos ganhos indiretos, os benefícios econômicos (renda) e sociais e como são percebidas pelos cooperados pessoas físicas. Essas transferências são conceitos abstratos investigados pela pesquisa, cuja amostra e coleta de dados são direcionadas para os aspectos qualitativos. 
A amostra é determinada durante a imersão inicial, podendo ser adaptada em qualquer momento do estudo. Na mesma investigação, o tamanho da amostra não é fixado a priori, mas será estabelecida a unidade de análise, porém, a amostra final somente será conhecida quando as unidades que vão sendo adicionadas não fornecerem informação ou novos dados. Utilizaram-se técnicas elaboradas para preservar, tanto quanto possível, o caráter representativo da amostra, ou seja, a pesquisa foi direcionada para manutenção da precisão da amostra. Entretanto, podem ocorrer diferenças caracterizadas por erros possíveis de acontecer entre as características da amostra e as da população de que foi retirada.

A amostra retrata bem as características da população que representa. Procura-se conduzi-la de forma apropriada, neutralizando as informações colhidas, sejam aquelas que subestimam, sejam as que superestimam os valores da população em estudo. Para que esse efeito anulador ocorra, serão preservados elementos suficientes na própria amostra, devendo ser conduzido o estudo de forma a não favorecer superestimativas nem subestimativas.

A construção do questionário consistiu em quatro etapas complementares: discussão teórica sobre o tipo de informação que se deveria coletar; contato com os profissionais das áreas técnicas sobre a existência das informações solicitadas e o método de aplicação que apresentaria melhor resultado; aplicação de questionário piloto in loco em diferentes cooperativas agropecuárias localizadas no Estado do Rio Grande do Sul; e, por fim, o ajuste final na forma de indagação das questões.

Dessa maneira, a análise é pautada em informações colhidas por meio do uso de amostras intencionais e selecionadas com questionários para conhecimento, qualificação de ganhos indiretos, de caráter não financeiro, a fim de possibilitar a percepção dessas transferências pelos cooperados (Apêndice 2).

O questionário autoadministrado é respondido pelo participante sem a presença do pesquisador. Os respondentes têm o conhecimento e a motivação para completá-lo sozinho, ante as orientações constantes nos documentos impressos. Procurou-se criar um conteúdo e formato atraente o suficiente para que os respondentes realmente o preenchessem e desenvolvessem o questionário, com empatia pelo estudo e interesse no resultado. 
Para Sampieri et alii (2006, p. 61), um questionário consiste em um conjunto de questões com relação a uma ou mais variáveis a ser medidas. $\mathrm{O}$ autor esclarece que o conteúdo das questões de um questionário é variado como os aspectos que ele mede, podendo ser considerados dois tipos de questão: fechado e aberto. Na pesquisa científica a ser realizada, os questionários serão entregues, por meio das sociedades cooperativas de produção agropecuárias, inclusive, as agroindustriais, via correio ou via abordagem eletrônica, evitando, sempre que possível, a perda de controle do pesquisador.

Optou-se, no questionário, pela modalidade de questões fechadas com várias alternativas de respostas. As categorias ou alternativas de respostas são delimitadas, definidas a priori, isto é, são apresentadas as possibilidades de respostas aos cooperados, e eles devem limitar-se a elas. Entretanto, para facilitar aos respondentes cooperados, as questões são formuladas com alternativas de respostas, permitindo a facilidade de codificar e preparar a análise. Por último, as questões fechadas são de tamanho médio, facilitando a colaboração dos respondentes cooperados, sem que ocorra a perda de informações.

Portanto, após a elaboração dos meios necessários para a coleta de dados qualitativos apropriados, com aplicação dos principais métodos, as entrevistas e os questionários, as informações decorrentes deverão ser organizadas para a análise desses dados.

O presente estudo foi direcionado também ao problema de pesquisa que procura investigar, como os cooperados pessoas físicas percebem as diferentes categorias de benefícios econômicos, colocados à disposição pela sociedade cooperativa de produção agropecuária. Primeiro, quando a organização gera resultado econômico e financeiro, na modalidade de sobras líquidas, apuradas anualmente, cuja parcela deve ser destinada à constituição do Fates. Segundo, inexistindo as sobras líquidas, questiona-se qual a sistemática de apuração de ganhos, classificados como indiretos, transferidos aos cooperados.

Assim, há necessidade de investigação, principalmente por haver relação muita estreita entre a proposição do problema e a revisão de literatura, permitindo a elaboração da seguinte questão de pesquisa, disposta na Figura 5. 


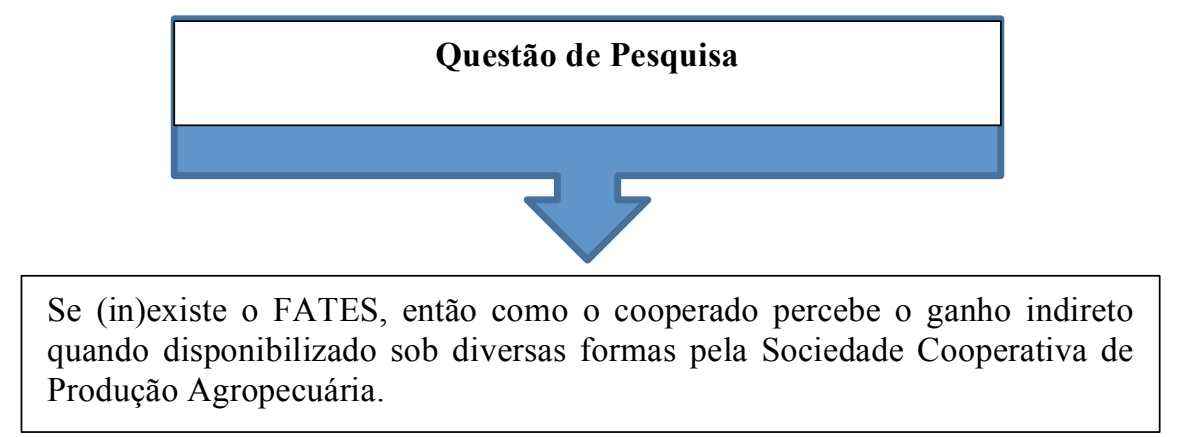

Figura 5 - Questões da pesquisa

Fonte: Autor

A questão de pesquisa procura investigar como o cooperado percebe o ganho econômico e não econômico em relação à sociedade cooperativa de produção agropecuária. Primeiro, quando a sociedade cooperativa apura anualmente resultado positivo, em forma de sobras líquidas, ou realiza operação com não cooperado (ato não cooperativo), e o lucro apurado decorrente, que também integra o Fates, proporciona recursos para suporte dos ganhos indiretos aos cooperados. Segundo, quando não se evidencia contabilmente a formação do Fates ou qualquer reserva com esse fim específico pela sociedade cooperativa de produção agropecuária.

Logo, para alcançar os objetivos pretendidos do trabalho, foram aplicados os questionários (Apêndice 2) em 200 (duzentos) cooperados das sociedades cooperativas, que colaboraram espontaneamente no fornecimento de dados, informações e declarações utilizados nesta análise.

\subsection{PROTOCOLO DE ESTUDO DE CASO}

O protocolo de estudo de caso é mais que um instrumento. Contém os procedimentos e as regras que devem ser seguidas, sendo uma etapa fundamental para a investigação e a coleta de dados objeto do trabalho, porque ele proporciona manter o alvo sobre o tópico do estudo de caso, sendo que o momento da sua preparação força o pesquisador a antecipar possíveis problemas, que somente poderiam ocorrer no decurso da realização da pesquisa. Yin (2010) destaca que o protocolo de estudo de caso é essencial quando se trata de estudo de casos múltiplos. É uma maneira importante de aumentar a confiabilidade da pesquisa, destinando-se 
a orientar o pesquisador na realização da coleta de dados, feita por meio de entrevistas e questionários.

De maneira geral, o protocolo de estudos de caso, segundo a visão geral do autor Yin (2010), deve ter as seguintes seções: (i) visão geral do estudo de caso, objetivos e patrocínios do projeto e assuntos do estudo de caso; (ii) procedimentos de campo (apresentação de credenciais, acesso aos locais do estudo de caso, linguagem à proteção dos participantes, fontes de dados e advertências de procedimentos); (iii) questões de estudo de caso, questões específicas de estudo de caso que o investigador deve ter em mente na coleta de dados, fontes de informações, entre outras; e (iv) um guia para o relatório do estudo de caso: esboço, formato para os dados, uso e apresentação de outra documentação e informação bibliográfica. Tomando por base o modelo proposto por Yin (2010), o protocolo de estudo de caso utilizado seguiu essas disposições para a coleta de dados das sociedades cooperativas de produção agropecuárias, como apresentado a seguir:

Quadro 3 - Protocolo de estudo de caso

\section{Introdução ao estudo de caso e finalidade do protocolo}

O estudo versa sobre as diferentes maneiras que as sociedades cooperativas de produção agropecuárias usam para adicionar valor econômico e social indireto e como esses valores são percebidos pelos cooperados. Iniciase a fundamentação teórica pela cooperação para explicar a forma mais eficiente de coordenação, capaz de representar vantagens maiores aos cooperados que os custos de renúncia a uma livre condição de mercado. Parte importante é a análise do ambiente institucional e a dimensão do direito de propriedade, além de estudar a sociedade cooperativa no contexto da teoria da firma e suas peculiaridades.

A linha teórica é dividida nos seguintes enfoques: (i) a sociedade cooperativa e a capacidade de gerar rendas lucros e sobras líquidas; (ii) os ganhos competitivos de eficiência; (iii) a percepção do cooperado pessoa física da renda e sua natureza segundo a teoria, como benefício, bem-estar, segurança, entre outras.

\section{Procedimentos de coleta de dados}

A coleta de dados da pesquisa foi realizada em documentos e trabalhos já publicados disponíveis sobre a temática, utilizando-se de entrevistas com os especialistas (Apêndice 1) com grau relativo de conhecimento técnico, que fossem capazes de explicar a correta apuração dos lucros e das sobras líquidas dessas organizações. As coletas de dados foram complementadas pelas respostas aos questionários junto aos cooperados (Apêndice 2), para identificar as diversas formas de percepção dos ganhos indiretos.

\subsection{Sociedades cooperativas}

Para realização desse estudo de campo, foi necessária a ajuda dessas instituições a fim de colher das pessoas qualificadas e, provavelmente, representativas do universo das maiores sociedades cooperativas localizadas e atuantes no Estado do Rio Grande do Sul.

\subsubsection{Sociedade Cooperativa A}

É uma cooperativa que recebe os produtos agrícolas e animais dos cooperados, destinados à industrialização e, posteriormente, à comercialização nos mercados interno e externo.

\subsubsection{Sociedade Cooperativa B}

Especializada em negociações com os mercados interno e externo das commodities agrícolas, a unidade de grãos proporciona vantagens competitivas, segurança na comercialização, além da possibilidade de realizar a troca de grãos por insumos agrícolas, operação que vem resultando em elevado nível de satisfação dos cooperados.

\subsubsection{Sociedade Cooperativa C}

Ela possui unidades de armazenamento e comercialização de produtos agrícolas, de assistência técnica agronômica e veterinária, de fornecimento de insumos agrícolas, além de lojas, supermercados e unidades de transportes.

\subsubsection{Sociedade Cooperativa D}

Detém mais de 1.100 associadas a entidade, sendo a produção orientada por técnicos que, diariamente, estão 
em contato com o produtor, fornecendo toda a assistência necessária. A equipe técnica se responsabiliza pelo acompanhamento permanente do processo industrial e pela qualidade final dos produtos, sempre com a atenção voltada para o desenvolvimento de uma tecnologia de ponta.

\subsection{Coleta de dados}

Para coleta dos dados, utilizaram-se entrevistas e questionários autopreenchíveis, que foram posteriormente recebidos das sociedades cooperativas via Sedex, em 24 de fevereiro de 2014, 30 de março de 2014 e 5 de maio de 2014: (i) as entrevistas foram realizadas com a presença do autor da pesquisa; tendo-se identificado, no perfil dos respondentes, o conhecimento técnico necessário, e elaborado 20 (vinte) questionamentos sobre a temática fundamentada, segundo a linha teórica da cooperação, o ambiente institucional, o direito de propriedade teórico da firma, a sociedade cooperativa e a capacidade de gerar renda, entre outras. (ii) os questionários foram formulados com base na revisão da literatura e respondidos por 50 (cinquenta) cooperados de cada sociedade cooperativa, sem a presença do autor da pesquisa.

Além do compromisso da não divulgação da razão social das sociedades cooperativas e dos dados de identificação dos cooperados, outras estratégias foram utilizadas, buscando-se maior nível de cooperação e autenticidade dos respondentes: a) solicitou-se o nome do entrevistado, cargo, localidade, e-mail e telefone, frisando-se a confidencialidade das respostas das entrevistas e dos questionários; b) a escolha dos cooperados respondentes dos questionários foi aleatória e de colaboração espontânea, com a participação de um responsável encarregado das explicações necessárias em caso de dúvidas sobre a temática. Foi possível diagnosticar a percepção dos cooperados dos benefícios econômicos e não econômicos do ganho indireto das sociedades cooperativas de produção agropecuária, traduzido pela sensação de segurança, o orgulho, a confiança, e a união. Essa percepção é qualificada pelo bem-estar dos cooperados.

Desse modo, as questões de pesquisas foram suficientes para realização do diagnóstico e concluir que os cooperados que integram o quadro societário das sociedades cooperativas de produção agropecuária percebem os ganhos indiretos, sem, no entanto, ser possível quantificá-lo objetivamente.

\section{Esboço da análise dos casos}

O estudo de caso foi realizado a partir das respostas às entrevistas e aos questionários, cuja temática constou da revisão bibliográfica e, na essência, tratava do instituto da cooperação, da capacidade das sociedades cooperativas para gerar renda, e de como são percebidos os benefícios econômicos e não econômicos pelos cooperados pessoas físicas, produtores rurais, decorrentes das transferências realizadas pela sociedade cooperativa de produção agropecuária.

$\mathrm{Na}$ investigação empírica dos fatos qualitativos foi possível entender o como e o porquê ocorrem as diversas transferências, normalmente, de forma gratuita aos cooperados pessoas físicas. As sociedades cooperativas possuem diferentes justificativas: "A" enfatiza que não só identifica as carências como procura levar e transferir tecnologias e conhecimentos a seus cooperados para que eles cresçam individual e coletivamente em conhecimentos técnicos, de mercado e gerais; "B" se manifesta de forma simples informando que procura realizar as transferências por meio de palestras técnicas e trabalho, dias em campo e em seminários; "C" explica que a participação em eventos para difundir melhores tecnologias são provas de que a reeducação tem que fazer parte do cotidiano dos cooperados; e "D" apresenta a forma expositiva mais esclarecedora, com argumentos de que normalmente os associados possuem grande conhecimento no cultivo de sua produção, sendo que estes buscam junto à cooperativa informações sobre insumos e defensivos agrícolas, tratamentos e prevenção de doenças da parreira, visando a maior produtividade e qualidade. A empresa, por seu turno, procura passar essas orientações e outras, tais como, guarda ou devolução de recipientes, cadernos de campos (histórico de época e tratamentos aplicados) e rastreabilidade dos produtos, que já se inicia nas propriedades. Nesse sentido, os associados respondem bem a essas orientações.

Portanto, as informações colhidas nas entrevistas e nos questionários permitiram a realização de cenários das ações de cooperação, identificando as principais variáveis como suporte para o mapeamento das percepções dos cooperados sobre o ganho indireto.

\section{Avaliação do Estudo de Caso}

Como resultados significativos, percebeu-se que, efetivamente, as sociedades cooperativas proporcionam condições para ofertar aos cooperados as oportunidades de aprendizagem. Esta é o conhecimento que pode ser transferido entre indivíduos, equipes e unidades organizacionais. A estrutura dessas organizações incluem armazenamento do sistema de crenças, das memórias de eventos passados, de história, de modelos de referência ou de valores. Assim, a aprendizagem é dinâmica e há mudanças constantes nos seus níveis, acrescido de um fluxo contínuo que se autor- reproduz.

Neste contexto, com muita força de explicação em relação às informações coletadas, a avaliação do estudo de caso esclareceu que os cooperados das sociedades cooperativas pesquisadas percebem os ganhos indiretos sob as mais diversas formas, tais como, os atributos "crédito para o cooperado", "fornecer insumos mais baratos", "disponibilidade de produtos veterinários" e "qualidade dos produtos", cuja consequência consiste em "melhorar sua atividade". A busca pela melhoria em sua atividade rural tem como efeito a "redução de custos" e "lucro maior", o que retorna sob a forma de "melhoria de sua atividade" e para "produtividade". 
Fonte: Autor 


\section{ANÁLISE E DISCUSSÃo DO RESULTADO}

\subsection{AS SOCIEDADES COOPERATIVAS NO CONTEXTO DA ANÁLISE}

\subsubsection{Sociedade Cooperativa Agroindustrial "A"}

A primeira sociedade cooperativa pesquisada tem claro o objetivo de "proporcionar aos associados a mais ampla defesa de seus interesses profissionais, comprar em comum, beneficiar, industrializar e comercializar a produção recebida, prestar, enfim, toda a assistência que estiver ao alcance da sociedade." Atualmente existem 10.465 cooperados, e 500 funcionários, com sede no leste do Rio Grande do Sul, doravante denominada de Sociedade Cooperativa Agroindustrial "A".

É uma cooperativa que recebe dos cooperados os produtos agrícolas e animais destinados à industrialização e, posteriormente, à comercialização no mercado interno e externo. Ela possui unidades de armazenamento e comercialização de produtos agrícolas, de assistência técnica agronômica e veterinária, de fornecimento de insumos agrícolas, além de lojas, supermercados e unidade de transportes.

\subsubsection{Sociedade Cooperativa Agroindustrial "B"}

Esta cooperativa foi fundada por um grupo de 27 agricultores gaúchos reunidos em busca da sustentabilidade de suas lavouras e preocupados com a preservação do meio ambiente. A sua filosofia e atuação estratégica conquistaram mais de 32 mil produtores rurais cooperados e suas unidades de negócios atravessaram fronteiras do estado do Rio Grande do Sul, possuindo 40 filiais, cuja linha de produção agrícola contempla as culturas de soja, arroz, milho, trigo, feijão, sorgo, cebola, alho, entre outros.

Com o lema "A rentabilidade é proporcional ao conhecimento por hectare", a área técnica se dedica à aplicação prática de conhecimento útil na solução de problemas enfrentados pelos agricultores, além de introduzir estratégias que aumentam a produtividade, com rentabilidade e qualidade. Localizada no centro do Rio Grande do Sul, os cooperados dispõem de moderna 
estrutura preparada para receber, armazenar e comercializar sua produção de grãos. Especializada em negociações com os mercados interno e externo das commodities agrícolas, a unidade de grãos proporciona vantagens competitivas e segurança na comercialização, além da possibilidade de realizar a troca de grãos por insumos agrícolas, operação que vem resultando em elevado nível de satisfação dos cooperados.

Ela também atua no processo de industrialização de grãos, tendo já conquistado importantes espaços no mercado brasileiro e trabalhando ativamente para se tornar referência internacional, como fornecedor de alimentos provenientes de técnicas sustentáveis de plantio. A unidade de alimentos da cooperativa comercializa a produção de seus cooperados através de marcas específicas, cunhadas com o selo de qualidade produto amigo do planeta.

\subsubsection{Sociedade Cooperativa Agroindustrial "C"}

Esta sociedade cooperativa está localizada no centro do Estado do Rio Grande do Sul e suas atividades são de abrangência estadual. O arroz beneficiado corresponde a $100 \%$ da produção recebida dos cooperados, e a soja "in natura" são os principais produtos destinados ao mercado interno e externo. A posição de destaque que ocupa em nível nacional há mais de três décadas foi possível graças à constante modernização de seu parque de armazenamento e industrialização, à alta tecnologia de suas unidades e aos rigorosos padrões exigidos nos processos de produção. Ela possui unidades de armazenamento e comercialização de produtos agrícolas, de assistência técnica agronômica e veterinária, de fornecimento de insumos agrícolas, além de lojas, supermercados e unidade de transportes.

\subsubsection{Sociedade Cooperativa Agroindustrial "D"}

A história desta sociedade cooperativa inicia-se em 1875, com a vinda de imigrantes oriundos do norte da Itália. Estabelecidos no sul do Brasil, numa localidade próxima à cidade de Porto Alegre, encontraram paisagem e clima similares aos do país de origem. Assim, os hábitos e a cultura europeia não foram abandonados, e a antiga arte da vitivinicultura logo foi retomada. No ano de 1931, dezesseis famílias de produtores de uvas reuniram-se para lançar a pedra fundamental do que viria a se transformar no maior empreendimento do gênero no Brasil: A sociedade cooperativa agroindustrial de produção de vinhos e derivados. Um ano mais tarde, 
já contabilizava a produção coletiva de 317 mil quilos de uvas e fixava a base de um empreendimento destinado a ser não apenas o maior, mas também um dos mais qualificados tecnologicamente.

Hoje, a sociedade cooperativa é a maior do Brasil. Mais de 1.100 famílias se associaram à entidade, sendo a produção orientada por técnicos que, diariamente, estão em contato com o produtor, fornecendo toda a assistência necessária. A equipe técnica se responsabiliza pelo acompanhamento permanente do processo industrial e pela qualidade final dos produtos, sempre com a atenção voltada para o desenvolvimento de uma tecnologia de ponta.

A posição de destaque que ocupa em nível nacional há mais de duas décadas foi possível graças à constante modernização de seu parque industrial, à alta tecnologia de suas unidades e aos rigorosos padrões exigidos nos processos de produção. $\mathrm{O}$ cuidado extremo com a rotina produtiva, observado a partir da plantação das mudas ao engarrafamento do produto, faz parte da receita de crescimento constante do empreendimento durante todos esses anos.

\subsection{O AMBIENTE COMPETITIVO DAS SOCIEDADES COOPERATIVAS}

Quando se discutem as estratégias de sociedades cooperativas de produção agropecuária em face do mercado, é importante analisar aquelas que são essenciais, dadas as suas dificuldades de utilização, o que pode ocorrer, em parte, com as estratégias de diversificação e, mais intensamente, com as estratégias de incentivos, regulação da concorrência, financeira e de capitalização.

A estratégia de produção das sociedades cooperativas passou a ser a busca pela integração vertical por meio da industrialização, com o objetivo claro de agregar valor aos produtos agropecuários dos cooperados, para evitar a simples intermediação comercial. Ou seja, os planos de organizações das sociedades cooperativas procuram agir de forma semelhante às sociedades empresariais no ambiente competitivo. 
Para Cechin (2014), entre os diferentes arranjos, as sociedades cooperativas enfrentam desafios particulares para se adaptarem às novas realidades dos mercados agrícolas contemporâneos, em razão de sua arquitetura organizacional. Os cooperados têm uma relação tríplice com a sua cooperativa (Barton,1989): de transação (uso), de propriedade e de controle.

No estudo de caso, verifica-se que as sociedades cooperativas se apresentam como organizações capazes de atuarem em mercados, sem discriminar os cooperados pessoas físicas, e, ainda, com vantagens de prover originalidade da produção, certificar qualidades e processos econômicos, sociais e ambientais. Ressalte-se, ainda, que, para cumprir as exigências do mercado, também estão passando por algumas importantes transformações que visam a obtenção de maior grau de eficiência econômica e competitiva.

Nesse sentido, as características da estrutura de mercado são de fundamental importância para o estudo e análise dos determinantes da competitividade do segmento cooperativo. Isso quer dizer que esses ramos do cooperativismo estão integrados a uma estrutura produtiva, com as características que lhe são peculiares, de produção, beneficiamento e comercialização de commodities agrícolas da soja, milho, e arroz, assim como o processo industrial da uva.

Dessa maneira, ficam evidentes e podem ser distintos, os vários aspectos específicos desses segmentos industriais, que atuam sob forma de sociedades cooperativas de produção agropecuária, com o tipo específico de produto agropecuário industrializado, as suas propriedades físicas e o seu nível de utilização variável, as características da demanda, o padrão de consumo, os tipos de insumos e os bens de capital utilizados diversificados, entre outros, permitindo a caracterização de cada sociedade cooperativa de maneira precisa e facilitando, assim, a percepção do benefício econômico e social que os vários ramos proporcionam aos cooperados e à região em que atuam.

As sociedades cooperativas agropecuárias, em face das exigências do mercado, estão passando por importantes transformações, para obtenção de maior grau de eficiência econômica e de posicionamento. É oportuno registrar as diversas formas de arquitetura das sociedades cooperativas que estão organizadas, seja com contratos de fidelidade e/ou de formas livres de cooperação, sem, contudo, ser possível identificar, na pesquisa, as várias 
coalizões realizadas ao longo prazo com outras organizações empresarias, tão relevantes para alcançar mais benefícios, como o bem-estar e a geração de valor para os cooperados.

Os dados e informações fornecidos por essas organizações são relevantes para análise e discussões, primeiro, sobre as formas de geração de renda; posteriormente, sobre a realização do mapeamento dos ganhos indiretos dos cooperados pessoas físicas, conforme a Figura 5 Sociedades Cooperativas: geração de rendas e ganhos indiretos.

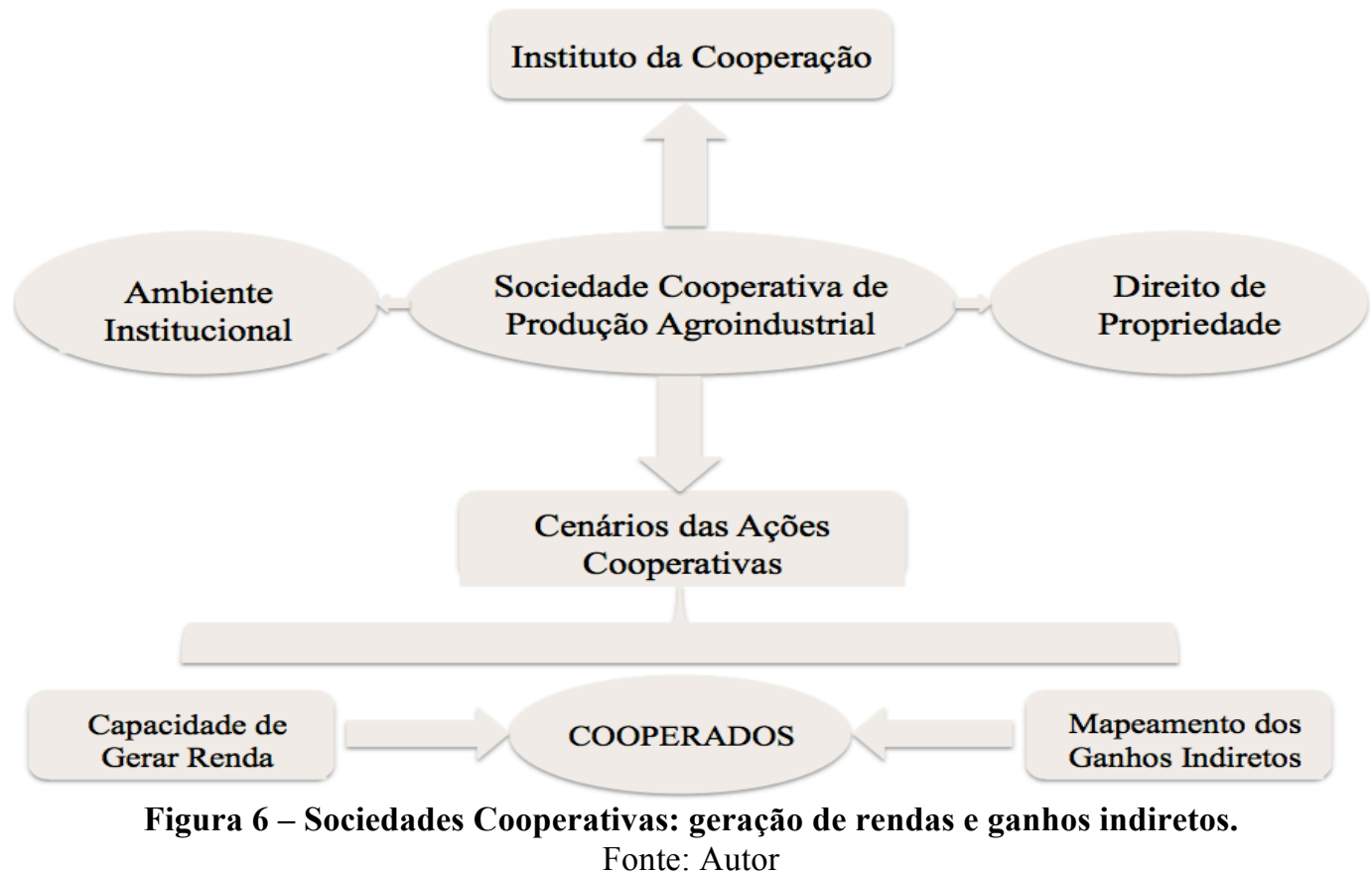

Nesta seção, são apresentadas as análises dos dados e informações da pesquisa sob esses enfoques e, por fim, o mapeamento das percepções dos cooperados acerca dos ganhos indiretos promovidos pelas sociedades cooperativas de produção agropecuária. Os enfoques devem ser acerca da existência de uma percepção da realidade como ela é, a partir do acesso às informações sobre as atividades desenvolvidas pelas sociedades cooperativas e, ainda, que não se fundam no aspecto quantitativo e, sim, no aspecto qualitativo oriundo das entrevistas com os técnicos especializados dessas organizações.

A percepção colhida no estudo é de que os cooperados passam a enxergar a sociedade cooperativa mais como uma opção de mercado, cujo direito de transacionar ele adquiriu ao se tornar membro, do que como sua propriedade. Nesta situação, a sociedade cooperativa cumpre apenas a função de atenuar falhas de mercado nos momentos em que são mais nocivas 
aos seus cooperados; estes têm menores incentivos para monitorar as ações do executivo e contribuir para sua administração, dificultando a adoção de estratégias de longo prazo, por parte da sociedade cooperativa.

Como analisado, a literatura já apresentou diversas críticas à política de sociedade cooperativa aberta. Por meio de um modelo, Leathers (2006) sugere que, mesmo com adesão voluntária, as sociedades cooperativas podem não ser eficientes para os produtores rurais, pois, à medida que o número de membros de uma sociedade cooperativa cresce e, simultaneamente, os custos médios individuais se reduzem, aumentando os custos de transação dos não cooperados, existe a possibilidade de os cooperados serem "varridos" para a sociedade cooperativa, mesmo que a maioria tivesse custos de transação mais baixos caso a cooperativa não existisse. Desta feita, é vantajoso para um produtor rural se associar, porque, quanto mais produtores fizerem parte da sociedade cooperativa, mais difícil será encontrar compradores para aqueles que permanecem sozinhos no mercado.

$\mathrm{Na}$ pesquisa, alguns aspectos relevantes sobressaem. Sob a ótica do escopo e a solidariedade social, a finalidade dessas organizações é latente e foi possível constatar, nas respostas dos entrevistados, a existência do respeito da ajuda mútua, da importância, e a relevância da questão social e econômica. No que se refere ao ambiente econômico desenvolvido, fica evidenciado o dever de proporcionar uma justa e equitativa distribuição da renda aos cooperados, cujo critério é quantificado pelos resultados apurados pela sociedade cooperativa e distribuídos proporcionalmente à participação econômica dos cooperados nos negócios realizados através do empreendimento cooperativo. $\mathrm{O}$ quadro $\mathrm{n}^{\circ} 4$ a seguir resume a opinião de cada sociedade cooperativa, onde se percebe também a ênfase à oferta de técnicas de conhecimentos relacionadas com a aprendizagem dos cooperados. 
Quadro 4 - Solidariedade, finalidade social e econômica

\begin{tabular}{|c|c|c|}
\hline Cooperativas & \multicolumn{2}{|c|}{ Respostas } \\
\hline "A" & \multicolumn{2}{|c|}{$\begin{array}{l}\text { A sociedade cooperativa de produção agropecuária tem como escopo a solidariedade } \\
\text { social e a comunhão de interesses comuns? RESPOSTA. Sim, a sociedade cooperativa } \\
\text { tem como objetivo primordial a ajuda mútua e o envolvimento coletivo de interesses em } \\
\text { detrimento do interesse individual. } \\
\text { Efetivamente, a finalidade principal da organização é a prestação de serviços aos seus } \\
\text { cooperados? RESPOSTA. Sim, como falamos anteriormente, os interesses e benefícios } \\
\text { devem atingir todos os produtores envolvidos com o empreendimento cooperativo. } \\
\text { Em caso positivo, o ambiente econômico desenvolvido propõe uma justa e equitativa } \\
\text { distribuição da riqueza produzida aos cooperados produtores rurais? RESPOSTA. Sim, } \\
\text { diretamente proporcional à sua participação econômica de negócios com o seu } \\
\text { empreendimento cooperativo. }\end{array}$} \\
\hline "B" & \multicolumn{2}{|c|}{$\begin{array}{l}\text { A sociedade cooperativa de produção agropecuária tem como escopo a solidariedade } \\
\text { social e a comunhão de interesses comuns? Sim, mas nunca esquecendo que, além da } \\
\text { questão social, existe também a questão econômica (se a Cooperativa não contiver } \\
\text { sobras, não existirá o social). } \\
\text { Efetivamente, a finalidade principal da organização é a prestação de serviços aos seus } \\
\text { cooperados? Sim. } \\
\text { Em caso positivo, o ambiente econômico desenvolvido propõe uma justa e equitativa } \\
\text { distribuição da riqueza produzida aos cooperados produtores rurais? Acredito que sim. } \\
\text { Atualmente, as técnicas empregadas na agricultura estão muito semelhantes. } \\
\text { Logicamente que aquele produtor rural que seguir com mais afinco as orientações da } \\
\text { nossa equipe técnica na utilização dos produtos de ponta, poderá ter um retorno maior na } \\
\text { sua lavoura. }\end{array}$} \\
\hline "C" & \multicolumn{2}{|c|}{$\begin{array}{l}\text { A sociedade cooperativa de produção agropecuária tem como escopo a solidariedade } \\
\text { social e a comunhão de interesses comuns? Efetivamente, a finalidade principal da } \\
\text { organização é a prestação de serviços aos seus cooperados? Em caso positivo, o } \\
\text { ambiente econômico desenvolvido propõe uma justa e equitativa distribuição da riqueza } \\
\text { produzida aos cooperados produtores rurais? Sim. }\end{array}$} \\
\hline \multirow[t]{6}{*}{ “D” } & \multicolumn{2}{|c|}{$\begin{array}{l}\text { A sociedade cooperativa de produção agropecuária tem como escopo a solidariedade } \\
\text { social e a comunhão de interesses comuns? Efetivamente, a finalidade principal da } \\
\text { organização é a prestação de serviços aos seus cooperados? Em caso positivo, o } \\
\text { ambiente econômico desenvolvido propõe uma justa e equitativa distribuição da riqueza } \\
\text { produzida aos cooperados produtores rurais? } \\
\text { A Cooperativa é composta atualmente por } 1.040 \text { associados }(31 / 12 / 2013) \text {, divididos em } \\
20 \text { núcleos, abrangendo as cidades de Bento Gonçalves, Monte Belo do Sul, Santa } \\
\text { Tereza, Veranópolis, Cotiporã, Guaporé, Dois Lajeados, São Valentin do Sul, } \\
\text { Farroupilha e Garibaldi-RS, pertencendo o maior número a Bento Gonçalves. } \\
\text { A Cooperativa recebe, em média, } 57 \text { milhões de quilogramas de uvas ao ano, } \\
\text { congregando a produção de } 596 \text { conjuntos familiares (tabela abaixo) que, isoladamente, } \\
\text { não teriam volume ou condições de concorrer no mercado, orientada pelas tendências, } \\
\text { identificadas pela empresa. Os associados contam com assistência técnica prestada por } \\
\text { técnicos e engenheiros agrônomos, funcionários, e encaminhamentos para assistência } \\
\text { social, também efetuada por funcionários. } \\
\text { O Conselho de Administração da empresa define o preço da produção a ser pago aos } \\
\text { associados, sendo que este tem sido sistematicamente acima do preço mínimo } \\
\text { determinado pelo Governo Federal. Após encerramento do período, são distribuídas } \\
\text { sobras, consideradas obrigações contratadas ou plano de investimentos. }\end{array}$} \\
\hline & Produção por Conjunto Familiar & $\mathrm{N}^{\circ}$ de Conjuntos Familiares \\
\hline & $0 \mathrm{a} 100.000 \mathrm{~kg}$ & 381 \\
\hline & $100.001 \mathrm{a} 200.000 \mathrm{~kg}$ & 162 \\
\hline & 200.001 a $300.000 \mathrm{~kg}$ & \\
\hline & Acima de $300.000 \mathrm{~kg}$ & 12 \\
\hline
\end{tabular}

Fonte: Informações das entrevistas realizadas pelo autor 


\section{3 É VISÍVEL O INSTITUTO DA COOPERAÇÃO?}

De início, identifica-se no estudo empírico que as sociedades cooperativas observaram alguns aspectos relevantes da linha teórica do instituto da cooperação, ou seja, as operações de comercialização dos produtos agropecuários dos cooperados e a prestação de serviços em geral ocorrem por meio dessas organizações, por prestarem melhor atendimento que a ação direta com o mercado. Neste contexto, constata-se que a sociedade cooperativa só é alternativa vantajosa se a coordenação das atividades econômicas dos agentes resultar em vantagens maiores que os custos da renúncia a uma condição de livre mercado. A decisão dos cooperados, de utilizar os meios disponibilizados pelas sociedades cooperativas, justifica a existência de um arranjo institucional em substituição à contratação direta da produção com o mercado. Ou seja, não haveria, obviamente, nenhum sentido em formar uma organização com essas características, quando uma ação individual independente pudesse servir aos interesses do indivíduo tão bem ou melhor que a própria organização.

A pessoa física produtor rural-cooperado utiliza-se da cooperação quando vê a possibilidade de maior satisfação de suas necessidades ao comparar com outras opções de ação existentes no mercado, a não-cooperação. É a premissa de que as organizações em geral existem tipicamente para promover interesses comuns de grupos de indivíduos. Essa é a principal constatação evidenciada nos dados e informações colhidas na pesquisa com especialistas dessas organizações. O quadro $\mathrm{n}^{\mathrm{o}} 5$ permite identificar as justificativas da formação da cooperação entre os cooperados, com uma posição clara dos benefícios na qualidade de vida, bem-estar e, consequentemente, o ganho indireto para os cooperados.

\section{Quadro 5 - Cooperação e relação contratual}

\begin{tabular}{|l|l|}
\hline Cooperativas & \multicolumn{1}{c|}{ Respostas } \\
\hline & $\begin{array}{l}\text { Na sociedade cooperativa, o instituto cooperação está diretamente envolvido nas } \\
\text { relações contratuais entre os cooperados? RESPOSTA. Sim } \\
\text { Quais as razões que justificam a formação de cooperação entre os cooperados? } \\
\text { RESPOSTA. Principalmente o ganho em escala. } \\
\text { O exercício da cooperação tem como propósito unicamente o benefício financeiro? } \\
\text { Não, o exercício da cooperação visa ao crescimento do cooperado e sua família } \\
\text { como ser humano, econômica e socialmente buscando mais conforto, qualidade de } \\
\text { vida, etc. }\end{array}$ \\
\hline
\end{tabular}




\begin{tabular}{|c|c|}
\hline "B" & $\begin{array}{l}\text { Na sociedade cooperativa, o instituto cooperação está diretamente envolvido nas } \\
\text { relações contratuais entre os cooperados? Sim. Quais as razões que justificam a } \\
\text { formação de cooperação entre os cooperados? Obter melhores resultados na sua } \\
\text { lavoura. Ver o que o outro cooperado esta fazendo, e copiar o que está dando certo. } \\
\text { Os dias de campo propiciam isto. O exercício da cooperação tem como propósito } \\
\text { unicamente o benefício financeiro? Sim }\end{array}$ \\
\hline "C" & $\begin{array}{l}\text { Na sociedade cooperativa, o instituto cooperação está diretamente envolvido nas } \\
\text { relações contratuais entre os cooperados? Sim. De forma ampla, o instituto da } \\
\text { cooperação é visível na organização. Quais as razões que justificam a formação de } \\
\text { cooperação entre os cooperados? Proporciona melhoria na atividade desenvolvida } \\
\text { por todos e fortalece a organização. O exercício da cooperação tem como propósito } \\
\text { unicamente o benefício financeiro? Não só o beneficio financeiro, mas a melhoria da } \\
\text { qualidade de vida do Cooperado. }\end{array}$ \\
\hline “D” & $\begin{array}{l}\text { Na sociedade cooperativa, o instituto cooperação está diretamente envolvido nas } \\
\text { relações contratuais entre os cooperados? Quais as razões que justificam a formação } \\
\text { de cooperação entre os cooperados? O exercício da cooperação tem como propósito } \\
\text { unicamente o benefício financeiro? A cooperativa teve e tem como principal } \\
\text { motivação a necessidade de industrializar e comercializar conjuntamente sua } \\
\text { produção. Esse acúmulo de esforços levou e leva necessariamente a benefícios } \\
\text { financeiros. Mas, além disso, a garantia da entrega da produção e a satisfação de } \\
\text { fazer parte e participar de uma "grande família", também são motivos dessa } \\
\text { cooperação. } \\
\text { Não há um propósito comum claramente explicitado. Muito da relação } \\
\text { Cooperativa/Cooperado vem da garantia de colocação da matéria prima, e do } \\
\text { recebimento por esta de um valor maior que o praticado no mercado. O fator } \\
\text { cooperativismo vem em segundo grau no interesse do Cooperado. }\end{array}$ \\
\hline
\end{tabular}

Fonte: Informações das entrevistas realizadas pelo autor

Por sua vez, os históricos dessas sociedades cooperativas permitem que se possa afirmar que as relações contratuais com os cooperados surgiram pela necessidade de gerar algumas vantagens econômicas e sociais. São informes relevantes colhidos nas entrevistas com os especialistas dessas organizações, a economia de escala na aquisição da informação, economia da aprendizagem e aumento da produtividade, entre outras.

A união desses cooperados motivou o surgimento de diferentes arranjos contratuais com culturas e características próprias, operacionalizadas pelas sociedades cooperativas, para atendimento das finalidades. Assim, é possível afirmar que o modelo de cooperação existente entre as sociedades cooperativas e os cooperados pode ser também uma estratégia empresarial de coordenação de comportamentos, implicando uma conjugação de esforços e de meios da organização envolvida no processo produtivo de vinho, soja, arroz, milho e insumos pecuários em geral. É o que se observa no quadro $n^{\circ} 6$ - As vantagens econômicas e não econômicas descritas no quadro a seguir: 
Quadro 6 - Vantagens e econômicas e não econômicas

\begin{tabular}{|c|l|}
\hline Cooperativas & \multicolumn{1}{c|}{ Respostas } \\
\hline \multirow{2}{*}{ "A" } & $\begin{array}{l}\text { A cooperação apresenta vantagens e desvantagens econômicas. Quais as principais } \\
\text { vantagens oportunizadas aos cooperados integrantes da organização? RESPOSTA. } \\
\text { Maior ganho em suas atividade, pela venda e aquisições em conjunto escala, além de } \\
\text { conhecimentos que a cooperativa transfere a seu cooperado. }\end{array}$ \\
\hline "B" & $\begin{array}{l}\text { A cooperação apresenta vantagens e desvantagens econômicas. Quais as principais } \\
\text { vantagens oportunizadas aos cooperados integrantes da organização? Obter melhores } \\
\text { resultados na sua exploração da atividade rural traduzida pelo compartilhamento do } \\
\text { conhecimento. Ver o que o outro cooperado esta fazendo, e copiar o que está dando } \\
\text { certo. }\end{array}$ \\
\hline "C" & $\begin{array}{l}\text { A cooperação apresenta vantagens e desvantagens econômicas. Quais as principais } \\
\text { vantagens oportunizadas aos cooperados integrantes da organização? Temos certeza } \\
\text { que a correta distribuição de valores aos cooperados, tanto na comercialização de } \\
\text { seus produtos quanto na aquisição dos insumos para implantação de suas lavouras. }\end{array}$ \\
\hline "D" & $\begin{array}{l}\text { A cooperação apresenta vantagens e desvantagens econômicas. Quais as principais } \\
\text { vantagens oportunizadas aos cooperados integrantes da organização? } \\
\text { Segurança na entrega da produção; nos últimos anos preços maiores que as empresas } \\
\text { privadas; distribuição de sobras; e assistência técnica dos agrônomos. Além das } \\
\text { vantagens já relacionadas em relação à produção, da garantia da entrega e do status } \\
\text { social, o número de associados propicia negociações vantajosas na compra de } \\
\text { insumos agrícolas, preços menores em planos de saúde e outros convênios. E todos } \\
\text { estes fatores em conjunto, uma qualidade de vida melhor. }\end{array}$ \\
\hline
\end{tabular}

Fonte: Informações das entrevistas realizadas pelo autor

Essa forma de cooperação, que ocorre por intermédio das sociedades cooperativas, mostra como tais organizações contratam os fatores de produção e os organizam para produzir e vender, iniciando a cadeia produtiva com os produtos agropecuários in natura, recebidos dos cooperados, até a finalização pela industrialização e comercialização ao consumidor final. Para organizar a produção, as sociedades cooperativas analisadas coordenam as decisões e as atividades econômicas de muitos indivíduos, ${ }^{16}$ sempre com o propósito de realizar as tarefas com mais eficiência que os mercados. Essa ideia de que as empresas existem porque há atividades nas quais elas são mais eficientes do que o mercado foi sugerida por Coase (1937), que se concentrou na capacidade de redução ou eliminação dos custos de transação. O quadro $\mathrm{n}^{\mathrm{o}} 7$ permite visualizar a posições dos entrevistados, em relação à vantagem e eficiência do modelo cooperativo.

Quadro 7 - Modelo societário cooperativo

\begin{tabular}{|c|c|c|}
\hline Cooperativas & \multicolumn{2}{|c|}{ Respostas } \\
\hline "A" & O modelo societário cooperativo tem-se considerado eficiente, econômica e \\
\hline
\end{tabular}

\footnotetext{
${ }^{16}$ Sociedade cooperativa "D", com atualmente 1.040 associados $(31 / 12 / 2013)$, recebe em média 57 milhões de quilogramas de uvas ao ano, congregando a produção de 596 conjuntos familiares que, isoladamente, não teriam volume ou condições de concorrer no mercado, orientada pelas tendências, identificadas pela empresa.
} 


\begin{tabular}{|l|l|}
\hline & $\begin{array}{l}\text { socialmente, resultando em vantagens maiores que os custos da renúncia a uma } \\
\text { condição de livre mercado? RESPOSTA. Hoje o cooperativismo, mesmo a reboque } \\
\text { do descaso governamental em incentivar econômica e financeiramente este tipo de } \\
\text { empreendimento, inclusive tributando a nossa prestação de serviço, consideramo- } \\
\text { nos capazes de distribuir renda aos cooperados envolvidos, melhor até mesmo que o } \\
\text { governo. }\end{array}$ \\
\hline O modelo societário cooperativo tem-se considerado eficiente, econômica e \\
socialmente, resultando em vantagens maiores que os custos da renúncia a uma \\
condição de livre mercado? Sim. O modelo cooperativo coordena a atividade \\
econômica de muitos cooperados e tem proporcionado mais vantagens, inibindo o \\
exercício da atividade individual a livre mercado.
\end{tabular}

Fonte: Informações das entrevistas realizadas pelo autor

A análise dos dados e informações fornecidos por essas organizações permite afirmar que as operações com os mercados ocorrem por meio de contratos de longa duração e com produtos determinados, mecanismos típicos dessas atividades econômicas analisadas. Nota-se que os contratos empresariais são usados para evitar ou diminuir os custos de transação, que consistem, fundamentalmente, em custos decorrentes da contratação com mercados. Dessa forma, a unidade básica de análise, quando se trata de custo de transação, é o próprio contrato.

Ante as peculiaridades das atividades econômicas desenvolvidas pelas sociedades cooperativas na contratação com os mercados, percebe-se que os custos de transação estão relacionados ao uso de determinados tipos de contrato das atividades agropecuárias, ao longo da cadeia produtiva, tais como o contrato de integração, o contrato de parceria, entre outros. Tais custos estão associados ao desenho dos contratos, como os de monitorar seu cumprimento, bem como de resolver problemas emergentes a partir do descumprimento.

Portanto, é possível afirmar que o modelo de cooperação existente entre as sociedades cooperativas e os cooperados implica uma conjugação de esforços e de meios da organização envolvida no processo produtivo e na economia da aprendizagem necessários para gerar o 
ganho indireto nas atividades operacionais.

\subsection{AS REGRAS DO JOGO FORMAIS E INFORMAIS}

De modo mais geral, o papel e a razão de ser das instituições consistem em que elas podem reduzir a incerteza ante a racionalidade limitada dos cooperados. Nesse ambiente econômico das sociedades cooperativas, a incerteza está no conhecimento individual adequado de cada cooperado para fazer escolhas e tomar decisões, que devem ser feitas e tomadas em conjunto: pela sociedade cooperativa e pelos cooperados.

A criação da riqueza nas economias regionalizadas do Rio Grande do Sul depende, substancialmente, das trocas em mercados, o que requer ambiente legal - com normas claras e de fácil aplicação - apto a aumentar a capacidade das partes (sociedade cooperativa e cooperados) no que diz respeito à definição dos termos para aperfeiçoar as condições de troca, de modo que garantam a produção da riqueza e a certeza quanto ao cumprimento dos contratos.

O ambiente institucional, referenciado nas entrevistas, é essencialmente composto pelas instituições formais, a Lei $n^{0} 5.764$ e n n $^{\circ}$ 10.406(BRASIL, 1971;BRASIL, 2002). Além disso, percebe-se que, no ambiente institucional, o efeito das leis sobre o comportamento dos agentes econômicos (sociedade cooperativa e cooperados) leva em conta, também, outras instituições informais, não escritas, e também os costumes, como o alicerce cultural, o comportamento ético nas transações mercantis e o respeito à organização.

Entretanto, as próprias normas institucionais não têm sido suficientes para diminuir as incertezas que são traduzidas em custos de transação. É o que se observa nas manifestações dos entrevistados, constantes do quadro $\mathrm{n}^{\circ} 8$, a seguir:

\section{Quadro 8 - Falhas do ambiente institucional}

\begin{tabular}{|c|l|}
\hline Cooperativas & \multicolumn{1}{c|}{ Respostas } \\
\hline & $\begin{array}{l}\text { Quais as principais falhas no ambiente institucional (leis, normas, entre outras) que } \\
\text { implicam restrições ao desenvolvimento da atividade econômica da organização } \\
\text { cooperativa em detrimento de maior ganho ao cooperado? } \\
\text { Tendo em vista que as cooperativas são meramente prestadoras de serviços, elas } \\
\text { deveriam ser isentas de qualquer forma de tributos, pois trata-se de compras e vendas } \\
\text { grupais, onde a cooperativa apenas facilita as transações. }\end{array}$ \\
\hline
\end{tabular}




\begin{tabular}{|l|l|}
\hline & $\begin{array}{l}\text { Quais as principais falhas no ambiente institucional (leis, normas, entre outras) que } \\
\text { implicam restrições ao desenvolvimento da atividade econômica da organização } \\
\text { cooperativa em detrimento de maior ganho ao cooperado? } \\
\text { A cooperativa agropecuária precisa tomar alguns cuidados (e com isto prejudica o } \\
\text { associado), pois caso contrário pode ser confundida como uma Cooperativa de } \\
\text { Consumo e aí sofrer toda uma carga tributária (que é superior)." }\end{array}$ \\
\hline "C" & $\begin{array}{l}\text { Quais as principais falhas no ambiente institucional (leis, normas, entre outras) que } \\
\text { implicam restrições ao desenvolvimento da atividade econômica da organização } \\
\text { cooperativa em detrimento de maior ganho ao cooperado? } \\
\text { Hoje, eu vejo com preocupação a alteração da 5.764, de 1971. Vejo ainda que é uma } \\
\text { legislação atual que protege os Cooperados e suas Empresas Cooperativas. }\end{array}$ \\
\hline "D" & $\begin{array}{l}\text { Quais as principais falhas no ambiente institucional (leis, normas, entre outras) que } \\
\text { implicam restrições ao desenvolvimento da atividade econômica da organização } \\
\text { cooperativa em detrimento de maior ganho ao cooperado? } \\
\text { A livre entrada de vinhos, principalmente da Argentina e do Chile, onde a carga } \\
\text { tributária sobre o vinho é baixa, provoca uma concorrência desleal com o vinho } \\
\text { brasileiro, que possui uma tributação muito alta. }\end{array}$ \\
\hline
\end{tabular}

Fonte: Informações das entrevistas realizadas pelo autor

Portanto, as sociedades cooperativas utilizam-se das instituições como elementos determinantes do desempenho econômico, no longo prazo. Esse ambiente institucional apresenta falhas apontadas nas entrevistas, sendo que devem ser aperfeiçoadas as disposições legais e normativas, para que haja o desenvolvimento do processo econômico. Verifica-se que o modelo da economia é o de essencialmente processadora de produtos agropecuários, constatando-se a existência de incerteza, com informação custosa e assimétrica, tendo as instituições que cumprir o papel de superar tais deficiências, como forma de diminuir os custos de transação, já que não são nulos. Para isso, é muito importante que exista um mercado adequado, capaz de garantir trocas econômicas eficientes, por meio da informação precisa e não assimétrica, facilmente comunicável, e um sistema de decisão acessível aos cooperados.

\subsection{O DIREITO DE PROPRIEDADE É BEM DEFINIDO?}

O principal argumento de Coase (1960) no artigo seminal "The problem of social cost" é que, se não houver custos de transação, então basta que os direitos de propriedade sejam bem definidos, para que os agentes voluntariamente negociem, de modo a levar os recursos ao uso mais eficiente. Trata-se de premissa verdadeira, entretanto, se nas atividades de natureza econômica das sociedades cooperativas os direitos de propriedade fossem bem definidos; 
consequentemente, se não houvesse custos de transação, o uso eficiente dos recursos pela atividade econômica dessas organizações deveria ser, automaticamente, atingido na plenitude.

Em regra, pode-se afirmar que há, sim, um direito comum de propriedade nas sociedades cooperativas, porém não bem definido. Cada cooperado tem poder de interferir no destino das organizações, não proporcionalmente à participação do capital social, mas de acordo com o princípio de, a cada cooperado, o direito a um voto. É evidente que, na ocorrência de um direito de propriedade entre muitos cooperados, este é confundido com recursos de livre acesso. Essa situação leva a outra, em que o direito de propriedade seja exercido por um grupo de cooperados com obrigações de gestão, de acordo com regras formais - estatuto social - e informais - costumes. Assim, os recursos disponíveis acabam por não ser totalmente explorados.

Por sua vez, não é o que se percebeu nos estudos empíricos em sociedades cooperativas, onde há pouca definição do direito de propriedade, originando custos de transação. Senão, vejamos: o direito de propriedade é, essencialmente, a capacidade de desfrutar de parte da propriedade, conforme Alchian (1987, p. 27) e Cheung (1969, p. 27). É o poder de obter renda, consumir ou alienar ativo de uma cooperativa, conforme preceitua Fulton(1995, apud BIALOSKORSKI NETO, 2012, p. 28). Nessas condições plenamente definidas, verifica-se que os cooperados não podem apropriar-se desse direito em forma de lucro residual, por expressas disposições na Lei n ${ }^{0} 5.764$ (BRASIL, 1971). A percepção apontada nas entrevistas versa sobre a pouca definição do direito de propriedade e, como mostra o quadro $\mathrm{n}^{\mathrm{o}} 9$, as informações não são precisas sobre esse direito, com conteúdo econômico à disposição aos cooperados.

\section{Quadro 9- Direito de propriedade}

\begin{tabular}{|c|l|}
\hline Cooperativas & \multicolumn{1}{|c|}{ Respostas } \\
\hline "A" & $\begin{array}{l}\text { A sociedade cooperativa tem consciência de que há um direito comum de } \\
\text { propriedade entre os cooperados? Sim. Quais são esses direitos? RESPOSTAS. Os } \\
\text { direitos previstos no Estatuto e na Legislação. }\end{array}$ \\
\hline & $\begin{array}{l}\text { A sociedade cooperativa tem consciência de que há um direito comum de } \\
\text { propriedade entre os cooperados? Quais são esses direitos? Sim. O patrimônio } \\
\text { Líquido da Cooperativa, representado pelo Capital Social, Sobras Líquidas e o Lucro } \\
\text { decorrente das operações realizadas com os não cooperados. }\end{array}$ \\
\hline
\end{tabular}




\begin{tabular}{|l|l|}
\hline "C" & $\begin{array}{l}\text { A sociedade cooperativa tem consciência de que há um direito comum de } \\
\text { propriedade entre os cooperados? Quais são esses direitos? Sim, respeito ao depósito } \\
\text { espontâneo de sua produção, com consequente disponibilização de recursos, a tempo } \\
\text { e na necessidade de cada Cooperado. }\end{array}$ \\
\hline "D" & $\begin{array}{l}\text { A sociedade cooperativa tem consciência de que há um direito comum de } \\
\text { propriedade entre os cooperados? Quais são esses direitos? } \\
\text { A Cooperativa, que pertence aos seus cooperativados, procura propiciar tratamento } \\
\text { igualitário para todos os associados em todos os assuntos, somente levando em } \\
\text { consideração o valor da safra, quando for aplicável este critério. }\end{array}$ \\
\hline
\end{tabular}

Fonte: Informações das entrevistas realizadas pelo autor

Observa-se que, no estudo empírico das sociedades cooperativas, o aspecto de relevância econômica é a definição do direito de propriedade. Essa definição é essencial para o desenvolvimento das atividades negociais, uma vez que se relaciona aos efeitos da atribuição de direitos sobre o comportamento dos produtores rurais, cooperados e agentes econômicos, e com o funcionamento dos mecanismos de mercado. Ou seja, sem a definição dos direitos de propriedade há prejuízos nas transações econômicas, com dificuldades de implantação e desenvolvimento dessas organizações. Dessa maneira, é possível afirmar que somente existirá uma definição do direito de propriedade, quando se constituir o objeto potencial de transações no mercado e, assim, contribuir para a criação e a organização de mercados e redução de custos de transação.

O estudo pautado nas informações colhidas nas entrevistas com os especialistas permitiu identificar que as sociedades cooperativas têm o poder de obter renda (resultado das operações com os não cooperados - atos não cooperativos) e vender bens do ativo não circulante. Entretanto, o resultado apurado deverá compor o Fates, quadro $n^{\circ} 10$, que tem destinação específica, como explicado no Capítulo 3 - A sociedade cooperativa de produção agropecuária e a capacidade de gerar rendas.

Quadro 10 - Criação do Fates

\begin{tabular}{|l|l|}
\hline Cooperativas & \multicolumn{1}{|c|}{ Respostas } \\
\hline & $\begin{array}{l}\text { O art. 28 da Lei no 5.764, de 1971, prevê a criação do Fundo de Assistência Técnica, } \\
\text { Educacional e Social (FATES), cuja origem decorre dos princípios dos pioneiros de } \\
\text { Rochdale: "dos ganhos, uma parcela seria destinada a um fundo para educação dos } \\
\text { membros cooperados." A sociedade cooperativa constitui anualmente o FATES? } \\
\text { "Além da parcela das sobras líquidas, qual(is) o(s) valor(es) que integra(m) o FATES? } \\
\text { RESPOSTA. Sim, a princípio somente o que determina a Lei, mas também usamos } \\
\text { recursos do Sescoop, e outros recursos de empresas parceiras e da própria } \\
\text { cooperativa para esta finalidade como por exemplo toda a assistência técnica é } \\
\text { gerada pela margem negocial em nosso caso valores superiores a dois milhões. }\end{array}$ \\
\hline
\end{tabular}




\begin{tabular}{|l|l|}
\hline & $\begin{array}{l}\text { O art. } 28 \text { da Lei no 5.764, de 1971, prevê a criação do Fundo de Assistência Técnica, } \\
\text { Educacional e Social (FATES), cuja origem decorre dos princípios dos pioneiros de } \\
\text { Rochdale: "dos ganhos, uma parcela seria destinada a um fundo para educação dos } \\
\text { membros cooperados." A sociedade cooperativa constitui anualmente o FATES? } \\
\text { Sim, exceto nos anos em que possui perdas no exercício. Além da parcela das sobras } \\
\text { líquidas, qual(is) o(s) valor(es) que integra(m) o FATES? Constitui apenas o } \\
\text { percentual legal de 5\% sobre as sobras líquidas. }\end{array}$ \\
\hline "B" & $\begin{array}{l}\text { O art. 28 da Lei no 5.764, de 1971, prevê a criação do Fundo de Assistência Técnica, } \\
\text { Rochdale: "dos ganhos, uma parcela seria destinada a um fundo para educação dos } \\
\text { membros cooperados." A sociedade cooperativa constitui anualmente o FATES? } \\
\text { Além da parcela das sobras líquidas, qual(is) o(s) valor(es) que integra(m) o FATES? } \\
\text { Sim, 5\% das sobras líquidas mais o resultado (lucro) com Não Associados. }\end{array}$ \\
\hline O art. 28 da Lei no 5.764, de 1971, prevê a criação do Fundo de Assistência Técnica, \\
Educacional e Social (FATES), cuja origem decorre dos princípios dos pioneiros de \\
Rochdale: "dos ganhos, uma parcela seria destinada a um fundo para educação dos \\
membros cooperados." A sociedade cooperativa constitui anualmente o FATES? \\
Além da parcela das sobras líquidas, qual(is) o(s) valor(es) que integra(m) o FATES? \\
O FATES é constituído anualmente, pelas sobras líquidas e pelo resultado do Ato \\
Não Cooperativo.
\end{tabular}

Fonte: Informações das entrevistas realizadas pelo autor

Partindo da definição de direitos de propriedade como a posse dos direitos sobre as receitas residuais e dos direitos residuais de controle, observa-se que a legislação cooperativista brasileira, no esforço de manter a propriedade e o controle da organização dispersos e de assegurar a soberania dos usuários sobre a cooperativa, acaba não alocando os direitos de propriedade da forma mais eficiente possível, criando diversos obstáculos para o melhor funcionamento. Em outras palavras, Cook (1994) afirma que, dadas as características particulares de uma cooperativa, a alocação dos direitos de propriedade leva a conflitos sobre os direitos residuais de controle e sobre as receitas residuais, elevando os custos de transação, principalmente quanto mais complexa for a estrutura organizacional da cooperativa.

Nesse contexto, as sociedades cooperativas, ao apurar resultado positivo das operações decorrentes do ato cooperativo denominado de sobras líquidas, e havendo decisão de Assembleia, podem destinar parte das sobras à constituição do Fates e o restante distribuir aos cooperados. É importante ficar consignado que o valor residual das sobras líquidas distribuídos pode constituir uma definição de direito de propriedade. Tal fato justifica o estudo das principais disposições legais e normativas sobre os registros de reconhecimento, a mensuração do lucro contábil e das sobras líquidas, classificadas no patrimônio líquido, fontes de recursos das sociedades cooperativas para o suporte dos encargos dos ganhos diretos e indiretos dos cooperados. 
Observa-se, no tocante aos direitos de propriedade, que estão divididos homogeneamente entre todos os associados devido ao princípio de gestão democrática que, entre outros pontos, estabelece o preceito de um homem - um voto. Por sua vez, os direitos sobre as receitas residuais não estão alocados na proporção do capital integralizado, sob a forma de quotaspartes, mas ao volume de operações realizadas na cooperativa.

Portanto, a definição dos direitos de propriedade é tida como fundamental para determinar os custos e benefícios associados ao uso dos recursos e a alocação destes entre indivíduos, estruturando os incentivos que determinam o comportamento econômico. As instituições que definem e alocam os direitos de propriedade podem afetar as decisões e, por decorrência, o comportamento econômico e os resultados, sendo que essas instituições abrangem tanto as regras formais do ordenamento jurídico estatal - constituição, leis, decisões judiciais - como os arranjos privados, convenções e costumes, com vista à alocação e uso do instituto do direito de propriedade. Entretanto, é possível afirmar que há pouca definição do direito de propriedade, constatado no estudo empírico das sociedades cooperativas de produção agropecuária, inclusive, as agroindustriais.

\subsection{CENÁRIOS DAS AÇÕES DE COOPERAÇÃO}

As investigações realizadas por meio de entrevistas com os técnicos especializados das sociedades cooperativas permitiram melhor compreensão dessa espécie de firma e suas particularidades, no que se refere à estrutura e função socioeconômicas. A partir das respostas às entrevistas, em cotejo com as ações realizadas e com a própria atividade operacional de cada agente econômico, foi possível identificar que as sociedades cooperativas priorizam o interesse comum, embora seja visível pelas informações, quando se manifestaram nas entrevistas, que, às vezes, torna-se difícil conciliar o pensamento de centenas ou milhares de cooperados com os propósitos da própria entidade.

As sociedades cooperativas possuem semelhanças quanto ao número elevado de cooperados (tamanho da firma), que são dispersos e com domicílio em várias localidades no Estado do Rio Grande do Sul. Tal fato não é motivador de trazer prejuízos no que se refere ao exercício da cooperação, principalmente pela ação prática inerente às negociações que são realizadas 
entre os cooperados e a própria sociedade cooperativa. Fica evidenciada a característica de uma nítida ponderação das propostas divergentes (solucionadas em Assembleia) entre os contratantes, nas decisões de cunho negocial. O aumento dos custos de governança cooperativa, seja pelos domicílios dispersos dos cooperados em diversas áreas geográficas de atuação, seja pelo número maior de cooperados, não tem sido obstáculo às sociedades cooperativas para o incentivo à participação dos cooperados nas atividades. As sociedades cooperativas são o propósito dos cooperados, ou seja, estes buscam os benefícios sociais e a eficiência econômica pela prática do ato cooperativo, configurado, principalmente, pela entrega da produção agropecuária à entidade, momento em que se identifica a principal característica dessas organizações: a ajuda mútua entre as partes relacionadas no contrato. Dessa maneira, é visível a cooperação socioeconômica nessa relação contratual entre a sociedade cooperativa e os cooperados.

A análise dos resultados evidencia que as sociedades cooperativas possuem como objeto a ajuda mútua. Além das questões sociais, existe em evidência o aspecto econômico, capaz de promover a justa distribuição de riqueza, principalmente pela adoção de técnicas empregadas na agropecuária, sem deixar de considerar a fidelização do cooperado e preços justos, entre outros. Dessa forma, os cooperados contam com assistência técnica prestada por técnicos, engenheiros agrônomos e funcionários e encaminhamentos para assistência social.

Dentre as sociedades cooperativas a "D" procura aproximar o máximo possível sua atuação aos interesses dos cooperados, embora nem sempre haja condições para tanto, visto estar inserida no mercado em iguais condições das demais vinícolas privadas. A transformação da uva em vinho, suco e espumante, bem como toda a assistência (técnica, social, jurídica) que é prestada ao cooperado, faz com que a prestação de serviços seja a principal finalidade da cooperativa, para o cooperado.

Na prática, essas sociedades cooperativas realizam a cooperação econômica, traduzida nas atividades desenvolvidas, que têm como base a linha teórica de Menard (2005), com a geração de vantagens para aqueles contratantes envolvidos na relação negocial: a economia de escala, a economia de escopo, a economia da aprendizagem, o consequente aumento de produtividade, com a manutenção das atividades do agronegócio. Nessas relações contratuais, a cooperação surge como estratégia empresarial de coordenação de comportamentos, implicando uma conjugação de esforços e de meios da organização envolvida na cadeia 
produtiva de grande variedade, começando pela produção agrícola e pecuária, entre outras, até a produção de vinho.

Essa cooperação é motivo de sucesso regional e se realiza por meio do estabelecimento de formas flexíveis de colaboração mútua, limitadas no objeto social e no tempo, com a prossecução de certos objetivos comuns, que são a prestação de serviços aos cooperados. E, ainda, a cooperação ocorre por intermédio das sociedades cooperativas, no papel de agentes institucionais que contratam os fatores de produção e os organizam, para produzir e vender bens e serviços. Para organizar a produção, as sociedades cooperativas coordenam as decisões e atividades econômicas dos cooperados, sempre com o propósito de realizar essas tarefas com mais eficiência do que os mercados. Aqui, o mercado é entendido como uma instituição que visa a criar incentivos, reduzir incertezas, facilitar operações entre a cooperativa e os cooperados, com nítido aumento de prosperidade e, portanto, de bem-estar geral, com a abrangência e o resultado positivo observado nas regiões atendidas por essas organizações.

O modelo utilizado pelas sociedades cooperativas existe e se fortalece no Estado do Rio Grande do Sul porque as atividades desenvolvidas - recebimentos de produtos agrícolas, inclusive, a produção de uvas, para industrialização e comercialização - têm sido mais eficientes do que o mercado, como se observa nos ensinamentos de Coase (1937), cujos efeitos decorrentes são a concentração na capacidade de redução ou eliminação dos custos de transações. Assim, as sociedades cooperativas, de alguma forma, podem estar economizando em custos de transações, beneficiando-se de economia de escala, escopo e aprendizagem e organizando a produção de forma mais eficiente. ${ }^{17}$ Em sentido contrário, os cooperados integrantes das entidades não estariam mais dispostos a se organizar em sociedade cooperativa justificada pela falta de benefícios socioeconômicos.

Impende acrescentar que as sociedades cooperativas pesquisadas propagam o proveito comum a todos os cooperados que decidiram pela cooperação, ou seja, o resultado direto econômicofinanceiro dos fatores de produção, quando decidido em Assembleia, é distribuído entre todos os cooperados em forma de sobras líquidas. Há, nessas organizações diversidades das atividades, entretanto, observa-se que o custo de administração e monitoramento, embora

\footnotetext{
${ }^{17} \mathrm{~A}$ eficiência da organização da tecnologia é medida em termos de ganho de escala e de escopo. É o quanto atesta Oliver Williamson, para quem a firma é, sobretudo, definida por economia de escala e escopo e é apenas um instrumento para transformar insumos em produtos, conforme as leis da tecnologia (CAVALLI, 2013, p. $160)$.
} 
elevado, não é suficiente para que o mercado possa ser mais eficiente na coordenação dos recursos. Ademais, os cooperados apresentam-se com formações semelhantes (exploração da atividade rural) e homogêneas (nível de formação fundamental), facilitando o desempenho da própria ação coletiva.

Ressalte-se, todavia, que nessas sociedades cooperativas há a presença de aproveitadores, principalmente, pelo elevado número de cooperados integrantes da relação contratual. Os aproveitadores, quando detectados, sofrem restrições por parte da organização política de controle, com o propósito de corrigir as irregularidades ou danos causados, haja vista as respostas aos questionamentos do quadro $\mathrm{n}^{\circ} 11$, a seguir

Quadro 11 - Influência do número de cooperados

\begin{tabular}{|c|c|}
\hline Cooperativas & Respostas \\
\hline "A" & $\begin{array}{l}\text { A influência de grande número de cooperados na organização pode motivar menos } \\
\text { eficiência do que os grupos com menos integrantes. Neste caso, a sociedade } \\
\text { cooperativa considera prejudicial a participação social de cada cooperado, por } \\
\text { motivar o aumento de custo da própria governança? RESPOSTA. Em princípio não } \\
\text { porque o cooperado tem sua participação ativa e apresenta resultado junto à } \\
\text { organização. Na formação dos grupos de cooperados identifica a presença de } \\
\text { aproveitadores? RESPOSTA. Sim. }\end{array}$ \\
\hline "B" & $\begin{array}{l}\text { A influência de grande número de cooperados na organização pode motivar menos } \\
\text { eficiência do que os grupos com menos integrantes. Neste caso, a sociedade } \\
\text { cooperativa considera prejudicial a participação social de cada cooperado, por } \\
\text { motivar o aumento de custo da própria governança? Não. Na formação dos grupos de } \\
\text { cooperados identifica a presença de aproveitadores? Como em qualquer tipo de } \\
\text { sociedade, sempre existem aqueles que querem apenas vantagens. }\end{array}$ \\
\hline "C" & $\begin{array}{l}\text { A influência de grande número de cooperados na organização pode motivar menos } \\
\text { eficiência do que os grupos com menos integrantes. Neste caso, a sociedade } \\
\text { cooperativa considera prejudicial a participação social de cada cooperado, por } \\
\text { motivar o aumento de custo da própria governança? Na formação dos grupos de } \\
\text { cooperados identifica a presença de aproveitadores? Toda a Cooperativa sofre com } \\
\text { os Cooperados imediatistas. Temos a obrigação de tratar os desiguais com } \\
\text { desigualdade. }\end{array}$ \\
\hline "D" & $\begin{array}{l}\text { A influência de grande número de cooperados na organização pode motivar menos } \\
\text { eficiência do que os grupos com menos integrantes. Neste caso, a sociedade } \\
\text { cooperativa considera prejudicial a participação social de cada cooperado, por } \\
\text { motivar o aumento de custo da própria govenança? Na formação dos grupos de } \\
\text { cooperados identifica a presença de aproveitadores? } \\
\text { Nesta sociedade cooperativa, a influência do grande número de associados é mais } \\
\text { sentida nos meses de fevereiro e março de cada ano, onde é efetuada a colheita e } \\
\text { entrega da produção, que de fato prejudica a governança da empresa (processo } \\
\text { industrial, planos de investimentos, finanças). Isso ocorre porque o próprio associado } \\
\text { tem suas despesas de colheita aumentadas, pois contrata terceiros para auxiliá-lo. } \\
\text { Assim, ele procura efetuar a colheita e entrega no menor tempo possível. Ocorre que } \\
\text { os demais associados também aplicam essa estratégia, transferindo para a empresa o } \\
\text { onus de processar, macerar ou limpar grandes quantidades em pouco tempo. Além de } \\
\text { prejudicar a qualidade, essa pressão acaba levando a investimentos que ficam } \\
\text { ociosos a maior parte do ano. A cooperativa busca a organização da colheita, mas, }\end{array}$ \\
\hline
\end{tabular}




\begin{tabular}{|l|l|}
\hline & $\begin{array}{l}\text { como o associado é dono, muitas vezes ocorrem atritos. Após a colheita, o fator } \\
\text { número de cooperados não interfere tanto na governança da sociedade. Quanto à } \\
\text { existência de aproveitadores, maior será a probabilidade quanto maior o número de } \\
\text { participantes, que se procura combater com mecanismos de controle e que muitas } \\
\text { vezes acaba na própria exclusão do associado. }\end{array}$ \\
\hline
\end{tabular}

Fonte: Informações das entrevistas realizadas pelo autor

Dessa maneira, se não forem corrigidas as irregularidades apontadas, por meio de controle, os indivíduos aproveitadores, que representam o oposto da cooperação, provocam perdas econômicas e financeiras às organizações com prejuízos a todos, uma vez que não se preocupam em contribuir para os objetivos comuns, apresentando grande anomalia ao sistema cooperativo. A existência de aproveitadores é tratada por Cook (1994), quando define sociedade cooperativa como organização. Isso porque, embora as organizações configurem uma arquitetura contratual, apresentam direitos de propriedade vagamente definidos, com problemas do carona - free-rider -, em que os benefícios da entidade acabam por albergar também membros não cooperativados. Os aproveitadores não têm atividades definidas, e os custos corporativos podem ser elevados, porque se utilizam dos resultados econômicos e financeiros com práticas irregulares ao arrepio da própria legislação do cooperativismo.

A representação gráfica na Figura $n^{\circ} 7$ resume o cenário de ações de cooperação, em que os cooperados integrantes de cada entidade podem usufruir dos benefícios socioeconômicos decorrentes da ação eficiente e redução ou eliminação dos custos de transação em cada sociedade cooperativa.

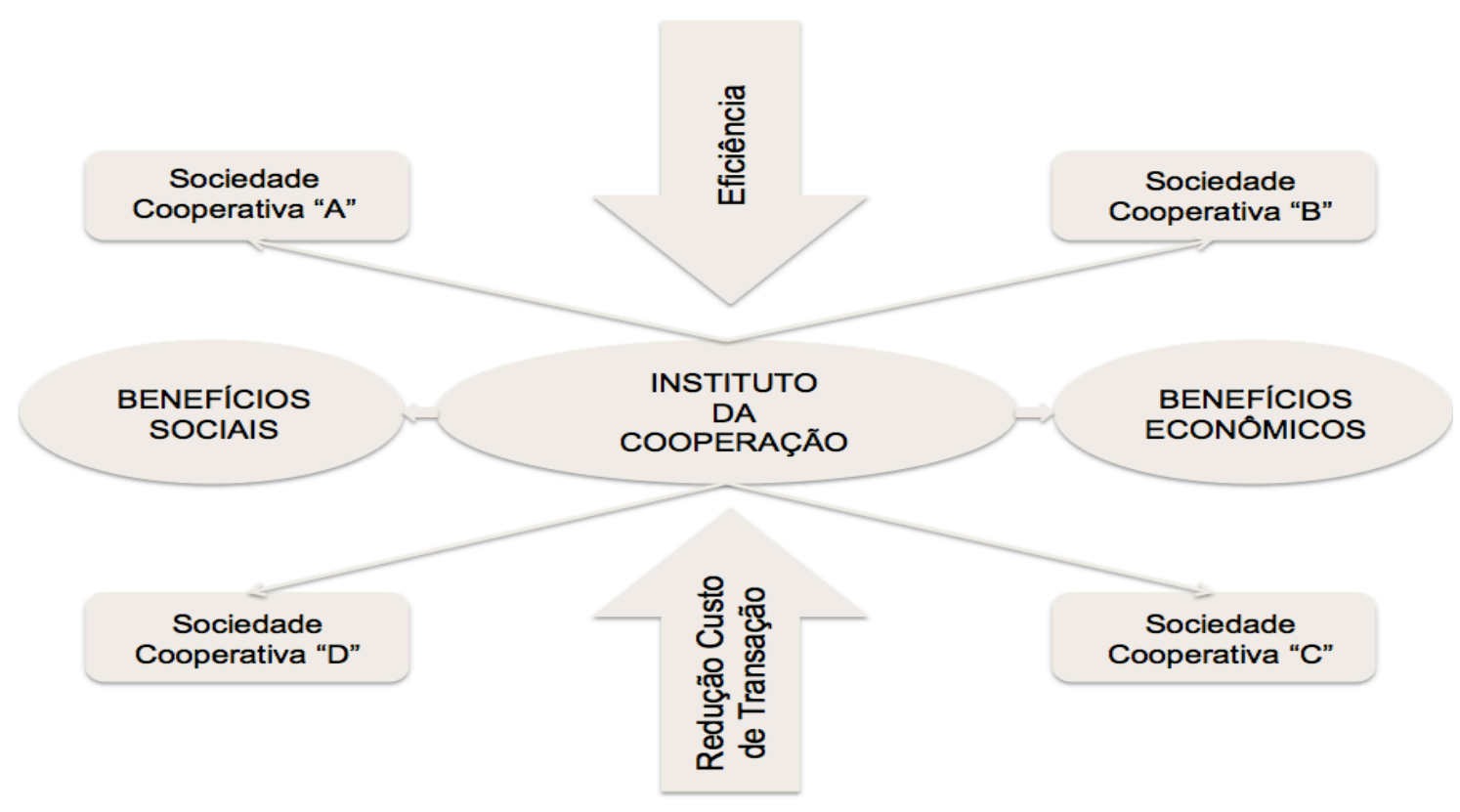




\section{Figura 7 - Instituto da cooperação}

Fonte: Autor

\subsection{SOCIEDADES COOPERATIVAS E GANHOS INDIRETOS DOS COOPERADOS}

As sociedades cooperativas, objeto de análise deste estudo, foram constituídas por pessoas físicas de mesmo grupo social e econômico, objetivando a realização de atividade relevante nesses segmentos. Identificam-se, nas relações contratuais, que foram aglutinadas forças de produção e capacidade de consumo para proporcionar melhores condições socioeconômicas aos cooperados e para a sociedade em geral, principalmente pela oferta da produção no mercado. Assim, as novas formas de organização foram constituídas para tirar proveito das oportunidades geradas pelo ambiente institucional, principalmente, e fortalecer a economia dos cooperados. É nesse sentido que se fortalece a ideia de sociedades de pessoas físicas, com formas próprias e constituídas para prestar serviços aos cooperados.

Entretanto, verifica-se que há manifestação negativa em relação ao ambiente institucional, principalmente sobre as regras específicas, porque não estão reduzindo as incertezas no mercado e, portanto, os custos de transação.

É importante ressaltar que, à medida que se desenvolvem, as novas formas de organização pressionam as instituições a se adaptar. Ou seja, quanto mais adaptáveis as instituições às novas formas de organizações (sem perder de vista, aqui, a necessidade de manter a previsibilidade das regras do jogo), maiores são as possibilidades de as organizações desempenharem a função de satisfazer as necessidades dos cooperados. Pela relevância socioeconômica, o Estado deveria criar o ambiente institucional necessário para o desenvolvimento dessas organizações, quando corresponderem às expectativas das demandas da sociedade.

Assim, é inegável a importância do ambiente institucional na caracterização das sociedades cooperativas, no que se refere ao desempenho econômico; isso permite que o arranjo entre unidades econômicas possa cooperar ou fornecer mecanismo para proporcionar mudanças nas leis ou mesmo no direito de propriedade. É o que se traduz das respostas colhidas em 
entrevistas com os especialistas dessas organizações: a mudança da legislação específica Lei $\mathrm{n}^{\mathrm{o}} 5.764$ (BRASIL, 1971).

$\mathrm{Na}$ perspectiva de mercado em que atuam, é possível afirmar que não se concebe sua existência sem que esteja direcionada para o mercado. Nesses segmentos econômicos, percebe-se que as leis do mercado condicionam a atividade empresarial, ou seja, ao longo do tempo, de uma posição primitiva, subjetivista, deslocou-se para o contexto evoluído, com o avanço do processo tecnológico em várias atividades em que operam, como soja, arroz, uva, entre outras. Em regra, observa-se que essas organizações representam unidades econômicas que produzem e empregam resultados destinados à cobertura de necessidades dos cooperados, procurando respeitar a economicidade e o equilíbrio financeiro. Ademais, as sociedades cooperativas permitem maior segurança, conhecimento, orgulho, entre outros, aos cooperados, inclusive na comercialização da produção, sendo possível afirmar a existência de preferência de negociação dos produtos agropecuários via organizações, como se observa a seguir.

\begin{abstract}
Sociedade Cooperativa " $D$ "
Embora cooperativas sejam bastante suscetiveis a desmandos em sua administração, usualmente os cooperados têm, sim, vantagens em relação a comercializar com empresas privadas. No caso da uva, nos últimos anos, a dificuldade na comercialização de vinhos fez com que empresas privadas reduzissem suas aquisições de matéria-prima, o que ocasionou perdas a muitos produtores. Por outro lado, as Cooperativas, embora inseridas no mesmo contexto, dão uma segurança para o Cooperado na entrega da produção e, também, de comercialização do produto transformado, o que lhe garante o recebimento pela matéria-prima.'
\end{abstract}

Vê-se, então, que não há posição unívoca de que as leis de mercado condicionam a atividade empresarial do cooperativismo, porque existem outros fatores (tributários) que de alguma forma provocam redução dos ganhos, destinados à cobertura das necessidades dos cooperados, a exemplo do descaso governamental referido por algumas das organizações, conforme a transcrição a seguir:

\title{
Sociedade Cooperativa “ $A$ ”
}

"Hoje o cooperativismo. mesmo a reboque do descaso governamental em incentivar econômica e financeiramente este tipo de empreendimento, inclusive tributando a nossa prestação de serviço, nos consideramos capazes de distribuir renda aos cooperados envolvidos, melhor até mesmo que o governo." 
A existência das sociedades cooperativas está relacionada à cooperação nas relações econômicas, que reside em organizar a produção mediante a concentração de todas as relações contratuais. Em termos de eficiência, as sociedades cooperativas estão remunerando os cooperados na proporção da entrega dos produtos (produtividade); com o pagamento das sobras líquidas apuradas anualmente, considerados ganhos diretos, e quando destinada parcela dessas sobras líquidas, esta é revertida para o aprimoramento do conhecimento dos cooperados, consideradas como ganhos indiretos. Constatou-se que há transferências pelas sociedades cooperativas, que são percebidas pelos cooperados na forma de ganhos pecuniários e não pecuniários. Os ganhos não pecuniários são relacionados ao status, conforto, conhecimento, segurança, entre outros, descritos como privilégio no âmbito da organização. Esses ganhos não são voltados ao aumento de riqueza, mas contribuem para o aumento do bem-estar de todos os cooperados, como se observa nas informações constantes do quadro $\mathrm{n}^{\mathrm{o}} 12$ a seguir.

Quadro 12 - Promoção do ganho indireto

\begin{tabular}{|c|c|}
\hline Cooperativas & Respostas \\
\hline "A" & $\begin{array}{l}\text { Como o modelo cooperativo adotado pela sociedade cooperativa pode promover o } \\
\text { ganho direto aos cooperados? RESPOSTA. Simplesmente porque estamos próximo } \\
\text { ao produtor e prestamos diversos serviços a eles. } \\
\text { Qual (is) a (s) forma (s) utilizada (s) pela organização para proporcionar o ganho } \\
\text { indireto não financeiro ao cooperado? RESPOSTAS. Como já nos referimos, a } \\
\text { cooperativa atua próximo às propriedades de seus cooperados, facilitando a logística } \\
\text { para o produtor, e devido às precárias condições de estradas junto às lavouras } \\
\text { produtoras o ganho é considerável. Além da logística, prestamos o serviço de } \\
\text { limpeza, secagem, armazenagem, conservação, assistência técnica agronômica e } \\
\text { veterinária etc. } \\
\text { É perceptível a melhoria econômica e não econômica do cooperado produtor rural? } \\
\text { RESPOSTA. É visível a melhoria econômica daquele produtor cooperativado, se } \\
\text { comparado com aquele não cooperativado, pois as cooperativas transferem } \\
\text { tecnologias e conhecimento importantes a seus cooperados através de reuniões com } \\
\text { este objetivo. }\end{array}$ \\
\hline "B" & $\begin{array}{l}\text { Como o modelo cooperativo adotado pela sociedade cooperativa pode promover o } \\
\text { ganho direto aos cooperados? Através da divulgação das melhores técnicas agrícolas; } \\
\text { dos melhores insumos, enfim pela melhor prestação de serviço ao associado. Qual } \\
\text { (is) a (s) forma (s) utilizada (s) pela organização para proporcionar o ganho indireto } \\
\text { não financeiro ao cooperado? Através da prestação de serviço técnico na lavoura do } \\
\text { associado. É perceptível a melhoria econômica e não-econômica do cooperado } \\
\text { produtor rural? Sim. A cada ano, o produtor tem conseguido melhores resultados na } \\
\text { sua lavoura. Salvo quando acontecem as intempéries climáticas. }\end{array}$ \\
\hline "C" & $\begin{array}{l}\text { Como o modelo cooperativo adotado pela sociedade cooperativa pode promover o } \\
\text { ganho direto aos cooperados? Qual (is) a (s) forma (s) utilizada (s) pela organização } \\
\text { para proporcionar o ganho indireto não financeiro ao cooperado? É perceptível a } \\
\text { melhoria econômica e não-econômica do cooperado produtor rural? Sim, os } \\
\text { Cooperados que são assistidos pela Assistência Técnica tem visíveis melhorias em } \\
\text { suas produções e, consequentemente, em sua qualidade de vida. }\end{array}$ \\
\hline
\end{tabular}




\begin{tabular}{|l|l|}
\hline & $\begin{array}{l}\text { Como o modelo cooperativo adotado pela sociedade cooperativa pode promover o } \\
\text { ganho direto aos cooperados? Qual (is) a (s) forma (s) utilizada (s) pela organização } \\
\text { para proporcionar o ganho indireto não financeiro ao cooperado? É perceptível a } \\
\text { melhoria econômica e não-econômica do cooperado produtor rural? } \\
\text { A vantagem mais perceptível para o associado e que gera ganho financeiro direto ao } \\
\text { associado é a garantia da entrega da produção. Esta normalmente ocorre por preços } \\
\text { mais elevados que o mercado e de acordo com a valorização de cada variedade (uvas } \\
\text { finas ou comuns), o que muitas vezes não ocorre com produtores não associados, que } \\
\text { precisam entregar sua produção por preços abaixo de seu valor real, por falta de } \\
\text { mercado e por ser produção que necessita ser processada até no máximo 2 dias após } \\
\text { a colheita, sob pena de perda total. A garantia da entrega da produção propicia } \\
\text { tranquilidade para os associados e motivação para aumentar, converter ou melhorar a } \\
\text { qualidade de seus produtos. } \\
\text { A Cooperativa possui uma marca forte, pelo que consegue bons resultados } \\
\text { econômicos. Estes resultados, conforme decisões do Conselho de Administração, se } \\
\text { revertem em preços maiores para a matéria prima e em pagamentos de sobras. E, } \\
\text { ainda, possui assistência técnica prestada por engenheiros agrônomos, que } \\
\text { diariamente estão a campo instruindo os cooperados para produzir mais e melhor. } \\
\text { Além disso, possui um setor de assistência social, que atende o cooperado nas suas } \\
\text { mais diferentes necessidades. }\end{array}$ \\
\hline
\end{tabular}

Fonte: Informações das entrevistas realizadas pelo autor

No tocante ao patrimônio das sociedades cooperativas, representado pelo conjunto de bens, direitos e obrigações registrados contabilmente, ele está sujeito à administração com a finalidade de auferir resultado, criar renda ou ganho aos cooperados. Há no patrimônio líquido o valor residual, cuja subclassificação no balanço patrimonial se refere aos recursos aportados pelos cooperados, as reservas resultantes de apropriações das sobras líquidas e de lucros, entre outras.

O resultado apurado por essas organizações é segregado na Demonstração de Resultado do Exercício (DRE), com a finalidade de evidenciar: o ato cooperativo, denominado de sobras ou perdas líquidas, e o ato não cooperativo, denominado de lucro ou prejuízo. Ou seja, o resultado quantifica a situação patrimonial e as mutações ocorridas em determinado período, permitindo apurar as sobras ou perdas líquidas decorrentes do ato cooperativo e o lucro ou prejuízo contábil resultante das operações realizadas com não cooperados.

Nas entrevistas, os especialistas explicam que as sobras líquidas ou resultado positivo entre a receita (ingressos) e os custos e as despesas (dispêndios) decorrem do resultado econômico, jurídico e financeiro apurado na escrituração comercial das sociedades cooperativas, vinculado às operações típicas classificadas como ato cooperativo. Neste caso, os cooperados são os beneficiários das sobras líquidas considerados como ganhos diretos. 
Em decorrência da apuração das sobras líquidas, as sociedades cooperativas pesquisadas constituem o Fundo de Reserva, que possui duas destinações bastante específicas, quais sejam: reparar perdas, assemelhando-se à compensação de prejuízos, e atender ao desenvolvimento de atividades operacionais, que podem ocorrer para o aprimoramento da tecnologia da informação utilizada pela sociedade cooperativa, além de financiamento de todas as atividades que proporcionam ganho e bem-estar aos cooperados, entre outras. Em sintonia com as regras societárias, os especialistas explicam a forma do cálculo do fundo de reserva, no mínimo de $10 \%$ das sobras líquidas do exercício, e do fundo de assistência técnica, educacional e social, destinado à prestação de assistência aos cooperados e familiares e, quando previsto nos estatutos, aos empregados da cooperativa, constituído de $5 \%$, pelo menos, das sobras líquidas apuradas no exercício.

Para a constituição e destinação desses valores - reserva e fundos -, são seguidas as disposições legais e normativas na integridade, ficando claro que os resultados positivos são suficientes para proporcionar o financiamento das atividades aos cooperados, condições para existência dos ganhos indiretos, conforme as informações do quadro $\mathrm{n}^{\circ} 13$, a seguir:

Quadro 13 - Geração de resultado positivo

\begin{tabular}{|c|l|}
\hline Cooperativas & \multicolumn{1}{c|}{ Respostas } \\
\hline "A" & $\begin{array}{l}\text { Qual a capacidade que a sociedade cooperativa possui para gerar resultados positivos } \\
\text { no período, e nos próximos anos, de forma gradual, segura e rentável, autos- } \\
\text { sustentando suas atividades operacionais e proporcionado ganhos aos cooperados? } \\
\text { RESPOSTA. Como temos planejamento estratégico e orçamentação não tem como } \\
\text { dar errado e só seguirmos os dois instrumentos buscando atingir os planos traçados. }\end{array}$ \\
\hline "B" & $\begin{array}{l}\text { Qual a capacidade que a sociedade cooperativa possui para gerar resultados positivos } \\
\text { no período, e nos próximos anos, de forma gradual, segura e rentável, autos- } \\
\text { sustentando suas atividades operacionais e proporcionado ganhos aos cooperados? } \\
\text { Infelizmente os resultados da cooperativa estão diretamente ligados aos ganhos dos } \\
\text { associados, que de certa forma estão ligados ao clima. Ou seja, se as condições } \\
\text { climáticas dos próximos anos for favorável, podemos afirmar que teremos condições } \\
\text { de obter resultados positivos e satisfatórios a todos os envolvidos. }\end{array}$ \\
\hline "C" & $\begin{array}{l}\text { Qual a capacidade que a sociedade cooperativa possui para gerar resultados positivos } \\
\text { no período, e nos próximos anos, de forma gradual, segura e rentável, autos- } \\
\text { sustentando suas atividades operacionais e proporcionado ganhos aos cooperados? } \\
\text { O agronegócio vive um extraordinário momento, mas temos que nos precaver com } \\
\text { relação aos mercados futuros. Mercado é mercado. }\end{array}$ \\
\hline "D" & $\begin{array}{l}\text { Qual a capacidade que a sociedade cooperativa possui para gerar resultados positivos } \\
\text { no período, e nos próximos anos, de forma gradual, segura e rentável, autos- } \\
\text { sustentando suas atividades operacionais e proporcionado ganhos aos cooperados? A } \\
\text { Cooperativa tem apresentado faturamentos crescentes e apurado sobras nos últimos } \\
\text { anos, permitindo a distribuição de parte dessas sobras, lembrando que o preço pago } \\
\text { ao seu associado tem sido sistematicamente superior ao preço definido pelo Governo } \\
\text { Federal. Ainda necessita de empréstimos de curto prazo para seu giro. }\end{array}$ \\
\hline
\end{tabular}




\begin{tabular}{|l|l|}
\hline & $\begin{array}{l}\text { Com referência a investimentos, tem efetuado com caixa do dia a dia ou obtido } \\
\text { financiamentos de longo prazo, uma vez que conta com boa imagem. Para o futuro, } \\
\text { busca-se a repetição deste passado, através de inovações e/ou ações seguras ("pés no } \\
\text { chão"). }\end{array}$ \\
\hline
\end{tabular}

Fonte: Informações das entrevistas realizadas pelo autor

A par dessa análise, é possível afirmar que as sociedades cooperativas de produção agropecuárias, inclusive, as agroindustriais, geram resultado econômico e financeiro fundamentado nas sobras líquidas apuradas anualmente, base para a constituição do Fates (Figura 7). Também, ficou explícito que, na hipótese de inexistência das sobras líquidas, os ganhos indiretos são concedidos de formas variadas, como mostram as respostas no quadro $\mathrm{n}^{\mathrm{o}}$ 14, a saber:

Quadro 14 - Capacidade de geração de resultado

\begin{tabular}{|c|c|}
\hline Cooperativas & Respostas \\
\hline "A" & $\begin{array}{l}\text { Na hipótese de a sociedade cooperativa não possuir capacidade econômica e } \\
\text { financeira, para gerar anualmente resultado positivo, sob a forma de sobras líquidas, } \\
\text { e/ou não destina esse valor, qual a sistemática de apuração de ganhos classificados } \\
\text { como indiretos que são transferidos aos cooperados? RESPOSTA. Neste caso, } \\
\text { somente os ganhos em informações tecnológicas e comerciais, bem como referências } \\
\text { comerciais referidas, pois a cooperativa está próxima de suas propriedades etc. }\end{array}$ \\
\hline "B" & $\begin{array}{l}\text { Na hipótese de a sociedade cooperativa não possuir capacidade econômica e } \\
\text { financeira, para gerar anualmente resultado positivo, sob a forma de sobras líquidas, } \\
\text { e/ou não destina esse valor, qual a sistemática de apuração de ganhos classificados } \\
\text { como indiretos que são transferidos aos cooperados? RESPOSTA. A forma de } \\
\text { transferência dos ganhos aos associados é através da assistência técnica. Nos últimos } \\
\text { anos, a cooperativa não distribuiu sobras (reinvestiu na própria cooperativa), pois foi } \\
\text { um período de imobilizações (fabrica, etc.) }\end{array}$ \\
\hline "C" & $\begin{array}{l}\text { Na hipótese de a sociedade cooperativa não possuir capacidade econômica e } \\
\text { financeira, para gerar anualmente resultado positivo, sob a forma de sobras líquidas, } \\
\text { e/ou não destina esse valor, qual a sistemática de apuração de ganhos classificados } \\
\text { como indiretos que são transferidos aos cooperados? RESPOSTA. Não consigo } \\
\text { imaginar uma Cooperativa sem sobras. É uma obrigação das Direções transformar as } \\
\text { Cooperativas em Empresas rentáveis, com distribuição de sobras. }\end{array}$ \\
\hline "D" & $\begin{array}{l}\mathrm{Na} \text { hipótese de a sociedade cooperativa não possuir capacidade econômica e } \\
\text { financeira, para gerar anualmente resultado positivo, sob a forma de sobras líquidas, } \\
\text { e/ou não destina esse valor, qual a sistemática de apuração de ganhos classificados } \\
\text { como indiretos que são transferidos aos cooperados? RESPOSTA. Por ora, a } \\
\text { Cooperativa, através de operações com terceiros e associados, tem gerado e } \\
\text { destinado recursos para o FATES. }\end{array}$ \\
\hline
\end{tabular}

Fonte: Informações das entrevistas realizadas pelo autor 


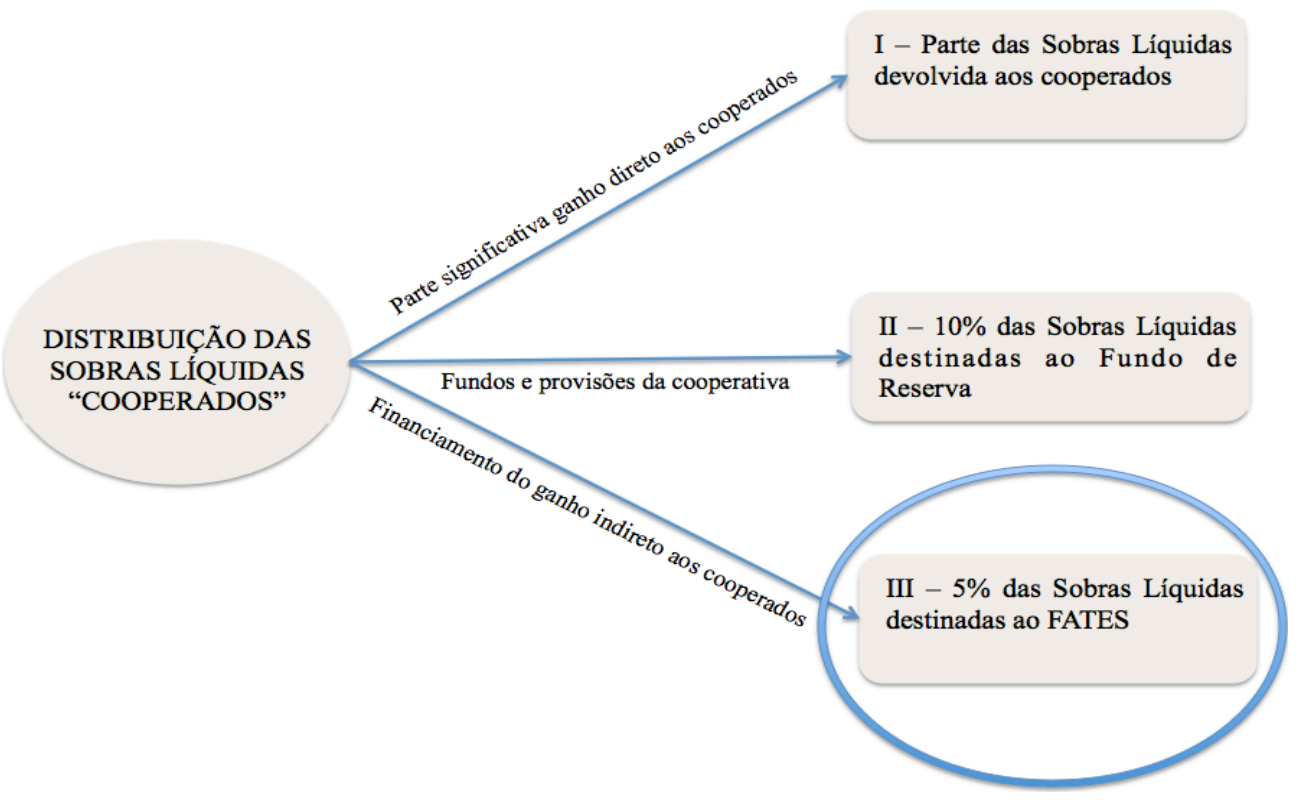

Figura 8 - Distribuição das sobras líquidas

Fonte: Autor

As sociedades cooperativas, em regra, procuram agir de forma semelhante às sociedades empresariais, no tocante à gestão em busca da operacionalidade de suas atividades junto aos cooperados, aplicando as normas de qualidade para o fornecimento, controle de qualidade dos produtos e o monitoramento dos processos produtivos dos cooperados.

Percebe-se que as sociedades cooperativas em análise adotam estratégias competitivas (gastos em aumento de eficiência produtiva, qualidade, inovação, propaganda, entre outras), com a finalidade de obter ou alcançar um certo nível de capacidade que favoreça a concorrência em preço, esforço de venda ou diferenciação de produtos, de acordo com o padrão de concorrência vigente no seu mercado específico. Ou seja, agindo dessa maneira, a competitividade depende da criação e renovação das vantagens competitivas por parte dessas organizações, em processo no qual cada produtor busca obter particularidades que o distingam favoravelmente dos demais, em termos de custo e/ou preço, qualidade, ritmo de inovação e habilidade de servir os próprios cooperados.

Em relação aos eixos estratégicos, as sociedades cooperativas devem converter as adequações de combinação de atividades desenvolvidas de valor, para conseguir custos menores em parcerias, a fim de obter novos recursos e captações, e as transferências de aptidões em vantagens competitivas. Assim, a geração de receita poderá decorrer de várias estratégias. 
Em relação ao instituto de coalizão, no qual a sociedade cooperativa poderá extrapolar as transações de mercado normais, embora o ambiente institucional brasileiro permita o arranjo contratual de participação societária em outras sociedades, a pesquisa não indicou que as organizações cooperativas tenham utilizado esses institutos para melhorar a geração de receita e diminuir os custos operacionais.

Por sua vez, fomentar a competitividade, em mercados cada vez acirrados, é uma tarefa de grande importância na atualidade, exigindo dos agentes a confiança no ambiente cooperativo. Ressalte-se que não há regras que dificultem ou restrinjam esse fomento, podendo ser utilizado para uma variedade ilimitada de objetivos.

As sociedades cooperativas pesquisadas estão localizadas em centros urbanos e a proximidade com outras organizações facilita relações negociais baseadas na confiança. Entretanto, devese destacar que os cooperados, por possuírem expectativas ligadas às trocas futuras com as sociedades cooperativas e, ainda, por compartilharem características comuns, tais como os laços de família, a religião, a cultura, entre outras, estão inseridos em um ambiente que permite a intensificação da confiança, possibilitando cada vez mais a cooperação. A confiança torna-se fator essencial para o ganho competitivo da organização cooperativa, resultando, ao final, em ganho indireto para o cooperado, fomentado pela melhora e consecução de tarefas por meio da aprendizagem.

Por último, no estudo percebe-se, também, comprometimento do cooperado com a organização cooperativa em que atua, caracterizado como uma atitude particularmente importante para os negócios, em vista de suas associações com outras atitudes, tais como a forma de produção agropecuária, a satisfação com o vínculo e com comportamentos dos indivíduos que influenciam a organização, em conformidade com o desempenho em tarefas e a rotatividade voluntária. 


\subsection{MAPEAMENTO DAS PERCEPÇÕES ECONÔMICAS E NÃO-ECONÔMICAS DOS COOPERADOS}

É sabido que as teorias que fundamentam a mensuração da renda auferida por pessoa física, na ótica do bem-estar, é tarefa notadamente difícil. Holmes (2001) afirma que a mensuração depende de fatores que não comportam exata quantificação, como, por exemplo, a felicidade ou a adequação da situação do indivíduo ao estilo de vida desejado. A própria conceituação de bem-estar contém em si um debate caloroso, que acresce as dificuldades em alcançar um consenso em torno de uma definição, uma vez que, em última instância, cada indivíduo, como o produtor rural, possui uma concepção própria do que venha a ser bem-estar.

Dessa forma, mesmo frente a tais obstáculos na mensuração do bem-estar, deve-se buscar alguma forma de percepção de ganho indireto, considerando sempre a premissa de que a renda refletida pelo bem-estar pode ser o parâmetro de uma qualificação mais justa, inclusive para fins de diferenciação dos produtores agropecuários pertencentes ao quadro societário das sociedades cooperativas de produção agropecuária, inclusive, as agroindustriais.

É nesse contexto que se restringiu o problema de pesquisa a verificar como ocorrem as transferências dos ganhos indiretos e como são percebidos os benefícios econômicos e não econômicos (renda) e sociais pelos cooperados pessoas físicas. Para alcançar os objetivos pretendidos do trabalho, foram aplicados questionários (Apêndice 2) para 200 membros das sociedades cooperativas, que colaboraram espontaneamente fornecendo dados, informações e declarações utilizados nesta análise.

De início, verificam-se algumas características dos cooperados que participaram da pesquisa e contribuíram para o mapeamento das percepções, sobressaindo as seguintes:

a) são majoritariamente do sexo masculino;

b) de modo geral, a média de escolaridade dos cooperados é o Ensino Fundamental incompleto, situação esta representativa da classe social em estudo, uma vez que é a realidade na agricultura familiar das várias regiões dos domicílios dos cooperados;

c) o número de pessoas da unidade familiar que trabalham e são beneficiados com a renda da propriedade rural corresponde, em média, a 4 (quatro) indivíduos; 
d) considerando a situação fundiária e as respostas aos questionários, foi possível identificar que a maioria dos entrevistados é detentora do imóvel rural utilizado na atividade explorada;

e) a diversidade das atividades agropecuárias implantadas pelos cooperados, considerada na pesquisa, provém do fato de tratar-se da agricultura familiar, pois, além de a mão-de-obra ser basicamente familiar, apresenta uma gama diversificada de cultivos agrícolas e pecuários;

f) quando questionados sobre os principais motivos pelo quais o produtor rural se associa às sociedades cooperativas, os respondentes apresentaram uma variedade de respostas, mas as principais razões foram: maior facilidade de comercialização da produção; busca de melhorias e conhecimentos técnicos para o desenvolvimento da atividade agropecuária; facilidade na compra e venda de produtos e insumos; prazos para pagamento das obrigações contraídas; opção de depositar e armazenar produtos, como grãos, entre outros, para esperar melhores preços de comercialização; busca e a entrega dos produtos na casa do produtor rural; e garantia de mercado para os produtos agropecuários;

g) de maneira geral, os cooperados conhecem os atos legais e normativos que fundamentam a relação contratual com a sociedade cooperativa;

h) os cooperados participam das assembleias, anualmente;

i) os cooperados percebem os serviços ofertados pela sociedade cooperativa, que tem motivado o aumento do conhecimento técnico e a melhoria da atividade produtiva; e

j) os serviços prestados de forma gratuita pelas sociedades cooperativas correspondem, em média, a R\$6.000,00, anualmente.

Nesse sentido, cabe destacar os ensinamentos de Knight et alii (1985) quando fazem referências aos três princípios representantes dos valores sociais cooperativos:

a) altruísmo - maximização do resultado de outrem;

b) igualdade - minimização da diferença entre o próprio resultado e o resultado de outrem;

c) grupo de valorização - maximização de ganhos conjuntos.

Já os valores sociais competitivos seriam distribuídos em: rivalidade, que minimiza o 
resultado de outrem, e superioridade, que maximiza o próprio resultado relativo. Por fim, os autores apresentam a distribuição do valor social individualista: individualismo maximiza o próprio resultado. Assim, torna-se notória a importância de valores sociais, como igualdade e grupo valorizado, para o bom desenvolvimento das organizações cooperativas, já que por meio destes se manifestam os ganhos indiretos, que são maximizados conjuntamente, sendo as diferenças individuais reduzidas (KNIGHT et alii, 1985).

Por sua vez, em diversos questionamentos aos cooperados em relação à visão que possuem das instituições, surgiram várias opiniões de potencialidades para uns e limitações para outros. Assim, não houve uniformidade de pensar e interpretar as informações, uma vez que existem diversas maneiras de pensar, e não se deve ignorar que em um mesmo indivíduo coexistem várias formas de pensar distintas ou contraditórias. É o que se verifica nas respostas aos questionamentos quando os cooperados apresentam contradições nas opiniões ao afirmar desconhecimento da política de distribuição das sobras líquidas, que ao final de cada período os beneficia diretamente pela distribuição e indiretamente pelas oportunidades de aperfeiçoamento profissional.

Analisando as informações colhidas nos questionários, é possível afirmar que o comportamento dos cooperados em relação à cooperativa é orientado principalmente por valores como: satisfação, orgulho, autoestima e realização, tranquilidade, família, segurança, confiança, união e cooperativismo. Foram esses valores que guiaram as ações, escolhas e julgamentos dos cooperados em relação à sociedade cooperativa e contribuíram de alguma forma para a identificação dos ganhos indiretos.

As assertivas de Seligman (1926 apud HOLMES, 2001) identificam-se com esses valores, ou seja, o ganho indireto como medida de riqueza é fundamentalmente psicológico, bem como histórico. As sensações de segurança, o orgulho, a confiança, a união e o cooperativismo são a verdadeira renda. Portanto, teoricamente, o ganho indireto é um conceito originário de renda, ou seja, a renda-prazer ou a renda-benefício. Parece claro, portanto, que a renda psicológica, que consiste na sensação de satisfação obtida pelo cooperado, decorre da utilização de determinados fluxos de sentimentos de satisfação, decorrentes de experiências psicológicas intangíveis.

Com força de explicação em relação aos dados dos questionários, tem-se como atributos 
crédito para o cooperado, fornecimento de insumos mais baratos, disponibilidade de produtos veterinários, qualidade dos produtos entregues pelos cooperados, serviços técnicos especializados, inovação tecnológica, bolsa de mercadorias e preço de transferências, que possuem como consequência melhoria da atividade rural. A busca por tal melhoria resulta em direta redução de custos e lucro maior e, indiretamente, em conhecimento técnico, bem-estar, segurança e tranquilidade, redirecionados à melhoria da atividade rural e da produtividade. Entretanto, deve-se atentar para valores como conhecimento, satisfação, tranquilidade, segurança. Embora existam, não é possível atribuir valores aos ganhos indiretos de natureza econômica e não econômica, que são percebidos pelos cooperados.

Exemplifica-se: O valor satisfação do cooperado tem relação direta com a melhoria na atividade rural. Trabalhar e ver a atividade prosperar gera satisfação para os cooperados. A paixão e a propriedade da terra podem ser ligadas ao valor satisfação. $\mathrm{O}$ atributo "cooperativa como compradora dos produtos produzidos pelo cooperado" (café, milho, uva etc.), que poderia ter muita importância como fator de união, também é visto de forma positiva, pois se liga à consequência "produtividade" com "ajuda ao cooperado na comercialização". Os atributos "cooperativa como suporte para o cooperado" e "agrupamento dos produtores em prol de um bem comum" ligam-se a duas consequências: "não ser explorado por terceiros" e "bem coletivo", que fazem com que surjam os valores "confiança" e "união e coletivismo". Todos são valores econômicos e não econômicos mapeados como ganho indireto pelos cooperados.

Impende acrescentar as potencialidades na percepção dos cooperados que responderam aos questionários em relação às sociedades cooperativas: ajuda muito os cooperados, principalmente na comercialização de insumos e escoamento da produção agropecuária; deve continuar a trabalhar em benefício dos cooperados para manter a estrutura adequada; deve continuar com o bom atendimento aos cooperados; deve aperfeiçoar a política de armazenamento, a "possibilidade de armazenar a produção para esperar melhores preços para a venda" -visto que é "administrada por cooperados se identifica com eles". Esses valores são percebidos indiretamente pelos cooperados, entretanto, não há como quantificá-los com objetividade.

Portanto, a sociedade cooperativa se apresenta em várias dessas situações analisadas, ofertando meios favoráveis e imprescindíveis para o desenvolvimento dos cooperados, 
podendo ser qualificada como uma organização com finalidade, em vez de mera prestadora de serviços. Por outro lado, também é possível observar as várias formas de ocorrências de transferências aos cooperados, que percebem os benefícios econômicos e não econômicos necessários ao desenvolvimento das atividades, principalmente representados pelas economias de aprendizagem, que diretamente resultam em reduções de custos unitários e indiretamente fortalecem os cooperados no acúmulo da experiência ao longo do tempo. Nesse contexto, não pode ser desprezada a melhoria do bem-estar do social do cooperado, manifestada pelo valor econômico de difícil mensuração pelo uso da tecnologia, da experiência acumulada, sendo responsável pela melhoria da capacidade e do conhecimento intelectual dos cooperados, para transformar as ideias econômicas criativas na melhoria da qualidade e da produtividade dos produtos agropecuários. 


\section{CONSIDERAÇÕES FINAIS}

Em linhas gerais, o estudo empírico permite identificar que, nas relações das sociedades cooperativas com os cooperados, ficam latentes alguns aspectos do instituto da cooperação, principalmente identificados nas operações típicas de ato cooperativo, qualificadas pela comercialização dos produtos agropecuários dos cooperados e prestação de serviços em geral por meio dessas organizações, por atendê-los melhor que a ação direta com o mercado.

O comportamento racional, entendido pelo desejo dos cooperados de melhorar a condição de vida, é juntado ao comportamento solidário, para que simultaneamente sejam alcançados objetivos redistributivos, melhoria dos mercados, bem-estar individual, desenvolvimento comunitário e a consequente dinamização, oportunizando a distribuição do ganho indireto.

A percepção, na análise, se resume ao fato de que a sociedade cooperativa pode ser a alternativa vantajosa, quando a coordenação das atividades econômicas dos agentes resultar em vantagens maiores que os custos da renúncia a uma condição de livre mercado. A decisão dos cooperados, de utilizar os meios disponibilizados pelas sociedades cooperativas, é justificada pela existência de um arranjo institucional em substituição à contratação direta de produção com o mercado.

No contexto histórico das sociedades cooperativas, as relações contratuais com os cooperados decorrem do mecanismo para regular as transações e são utilizadas para reduzir riscos e incertezas no processo de troca de produtos ou mercadorias. As relações contratuais surgiram pela necessidade de gerar algumas vantagens econômicas e sociais, como a economia de escala na aquisição da informação e de aprendizagem e o aumento da produtividade, entre outras. Sobressai para os ganhos indiretos a economia da aprendizagem.

O ambiente institucional referenciado nas entrevistas é essencialmente composto pelas instituições formais, a Lei $n^{0} 5.764$, de 1971, e a Lei $n^{0} 10.406$, de 2002. Embora se perceba que no ambiente institucional o efeito da legislação sobre o comportamento dos agentes econômicos (sociedade cooperativa e cooperados) leva em conta, também, outras instituições informais, não escritas, e os costumes, como o alicerce cultural dos cooperados de descendência estrangeira, o comportamento ético nas transações mercantis e o respeito à própria organização. 
A premissa básica na análise do estudo empírico é que, nas atividades de natureza econômica das sociedades cooperativas, os direitos de propriedade sejam bem definidos e, consequentemente, não haja custos de transação, devendo o uso eficiente dos recursos pela atividade econômica dessas organizações ser automaticamente atingido na plenitude, proporcionando melhores ganhos indiretos aos cooperados.

A partir das respostas às entrevistas, em cotejo com as ações realizadas com a própria atividade operacional de cada agente econômico, foi possível identificar que as sociedades cooperativas priorizam o interesse comum, embora seja visível, nas afirmações técnicas, que às vezes se torna difícil conciliar o pensamento de centenas ou milhares de cooperados com os propósitos da própria organização.

As sociedades cooperativas possuem semelhanças quanto ao número elevado de cooperados (tamanho da firma), que são dispersos e com domicílios em várias localidades no Estado do Rio Grande do Sul. Tal fato não é motivador para ocasionar prejuízos às atividades decorrentes do exercício da cooperação, principalmente, porque a ação prática inerente às negociações mercantis é realizada, preponderantemente, entre os cooperados e a própria sociedade cooperativa.

Nesse sentido, fica evidenciada a característica de nítida ponderação das propostas divergentes (solucionadas em Assembleia) entre os contratantes das sociedades cooperativas e os cooperados, nas decisões de cunho negocial. O aumento dos custos de governança cooperativa, seja pelos domicílios dispersos dos cooperados em diversas áreas geográficas de atuação, seja pelo maior número de cooperados, não tem sido obstáculo às sociedades cooperativas para o incentivo à participação dos cooperados nas atividades de interesse comum. Entretanto, o aumento do custo da governança pode, sim, ser constatado, quando comparado às atividades das sociedades cooperativas com as sociedades não cooperativas, principalmente levando em consideração a especificidade dos ativos de cada organização.

O modelo utilizado pelas sociedades cooperativas existe e se fortalece no Estado do Rio Grande do Sul, porque as atividades desenvolvidas - recebimentos dos produtos agrícolas -, inclusive na produção de uvas para industrialização e comercialização, têm sido mais eficientes do que o mercado, cujos efeitos decorrentes são a concentração na capacidade de redução ou eliminação dos custos de transações. 
As sociedades cooperativas, de alguma forma, podem economizar em custos de transações, beneficiando-se de economia de escala, escopo e aprendizagem e organizando a produção de forma mais eficiente. Em sentido contrário, os cooperados integrantes dessas entidades não estariam mais dispostos a se organizar em sociedade cooperativa, principalmente pela falta de benefícios econômicos ou sociais.

O estudo empírico pautado nas informações colhidas nas entrevistas com os especialistas permite afirmar que as sociedades cooperativas têm, sim, o poder de obter renda (resultado das operações com os não cooperados - atos não cooperativos) e vender bens do ativo não circulante. Entretanto, o resultado apurado deverá compor o Fundo de Assistência Técnica, Educacional e Social (Fates), que tem destinação específica.

As sociedades cooperativas, ao apurar resultado positivo das operações decorrentes do ato cooperativo denominado de sobras líquidas, e havendo decisão em assembleia, destinam parte das sobras para constituição do Fates, podendo o restante ser distribuído aos cooperados. Pode-se afirmar que esse valor residual das sobras líquidas distribuídos constitui uma definição de direito de propriedade de uso limitado pelos cooperados.

Constatou-se que há transferências indiretas pelas sociedades cooperativas que são percebidas pelos cooperados em forma de ganhos pecuniários e não pecuniários. Os ganhos não pecuniários são relacionados ao status, conforto, conhecimento, segurança, entre outros, descritos como privilégios no âmbito dessas organizações. Tais ganhos não são voltados ao aumento de riqueza, mas contribuem para o aumento do bem-estar de todos os cooperados.

Analisando as informações colhidas nos questionários, é possível afirmar que o comportamento dos cooperados em relação à sociedade cooperativa é orientado principalmente por valores como satisfação, orgulho, autoestima e realização, tranquilidade, família, segurança, confiança e união e cooperativismo. Foram esses valores que guiaram as ações, escolhas e julgamentos dos cooperados em relação à sociedade cooperativa e contribuíram de alguma forma para a identificação dos ganhos indiretos.

Identifica-se a transferência e a percepção pelos cooperados do ganho indireto como medida de riqueza do bem-estar. As sensações de segurança, o orgulho, a confiança, a união e o cooperativismo podem ser consideradas renda. Parece claro, portanto, que a renda psicológica (HOLMES, 2001), que consiste na sensação de satisfação obtido pelo cooperado, decorre da 
utilização de determinados fluxos de sentimentos, de satisfação, decorrentes de experiências psicológicas intangíveis.

Cabe acrescentar as potencialidades na percepção dos cooperados que responderam aos questionários em relação às sociedades cooperativas: ajuda aos cooperados na comercialização de insumos e escoamento da produção agropecuária; deve continuar a trabalhar em benefício dos cooperados para manter a estrutura adequada; com o bom atendimento aos cooperados; aperfeiçoar a política de armazenamento "possibilidade de armazenar a produção para esperar melhores preços para a venda", como é "administrada por cooperados se identifica com eles". Esses valores são percebidos indiretamente pelos cooperados, entretanto, não há como quantificá-los com objetividade.

Observam-se várias formas de transferência aos cooperados, que percebem os benefícios econômicos e não econômicos no desenvolvimento de sua atividade, principalmente representados na economia de aprendizagem, que diretamente traz redução de custo unitário e indiretamente fortalece os cooperados no acúmulo da experiência ao longo do tempo.

Percebe-se que as sociedades cooperativas em análise adotam estratégias competitivas (gastos em aumento de eficiência produtiva, qualidade, inovação, propaganda, entre outras), com a finalidade de obter ou alcançar um certo nível de capacidade que favoreça a concorrência em preço, esforço de venda ou diferenciação de produtos, de acordo com o padrão de concorrência vigente no seu mercado específico. Ou seja, agindo dessa maneira a competitividade depende de criação e renovação das vantagens competitivas por parte dessas organizações, em processo no qual cada produtor busca obter particularidades que o distingam favoravelmente dos demais, em termos de custo e/ou preço, qualidade, ritmo de inovação e habilidade de servir os próprios cooperados.

Em relação aos eixos estratégicos, as sociedades cooperativas devem converter as adequações de combinação de atividades desenvolvidas de valor, para conseguir custos menores em parcerias para obtenção de novos recursos e captações, e as transferências de aptidões em vantagens competitivas. Assim, a geração de receita poderá decorrer de várias estratégias.

Em relação ao instituto de coalizão, no qual a sociedade cooperativa poderá extrapolar as transações de mercado normais, embora o ambiente institucional brasileiro permita o arranjo contratual de participação societária em outras sociedades, a pesquisa não indicou que as 
organizações cooperativas tenham utilizado esses institutos para melhorar a geração de receita e diminuir os custos operacionais.

As sociedades cooperativas pesquisadas estão localizadas em centros urbanos e a proximidade com outras organizações facilita relações negociais baseadas na confiança. Entretanto, devese destacar que os cooperados, por possuírem expectativas ligadas às trocas futuras com as sociedades cooperativas e, ainda, por compartilharem características comuns, tais como os laços de família, a religião, a cultura, entre outras, estão inseridos em um ambiente que permite a intensificação da confiança, possibilitando cada vez mais a cooperação. A confiança torna-se fator essencial para o ganho competitivo da organização cooperativa, resultando, ao final, em ganho indireto para o cooperado, fomentado pela melhora e consecução de tarefas por meio da aprendizagem.

No estudo percebe-se, também, o comprometimento do cooperado com a organização cooperativa em que atua, caracterizado como uma atitude particularmente importante para os negócios, em vista de suas associações com outras atitudes, quais sejam a forma de produção agropecuária, a satisfação com o vínculo e com comportamentos dos indivíduos que influenciam a organização, como o desempenho em tarefas e a rotatividade voluntária.

Esta tese, apesar das limitações inerentes a qualquer trabalho de pesquisa, realizou-se um esforço para averiguar o seguinte: Diante da existência de ganhos socioeconômicos indiretos de caráter não financeiro, como são percebidos esses benefícios econômicos e não econômicos pelos cooperados pessoas físicas, produtores rurais, decorrentes das transferências realizadas pela sociedade cooperativa de produção agropecuária.

As respostas colhidas nas entrevistas e nos questionários foram suficientes para entender que os cooperados percebem os ganhos indiretos, principalmente em forma de economia da aprendizagem. Espera-se que este esforço possa, de alguma forma, estimular a produção de novos trabalhos, pesquisas ou busca por informações. Assim como todo o processo de produção de conhecimento científico, os passos são dados de forma lenta e custosa, mas na direção da agregação de novo conhecimento. 


\section{REFERÊNCIAS BIBLIOGRÁRICAS}

ALCHIAN, Armen A. Some economics of property rights. Il Politico 30, no. 4: 816-29. Reprinted in ALCHIAN,Armen A. Economic forces at work. Indianapolis, Ind.: Liberty Press, 1965.

ALCHIAN, Armen A. Property Rights. In The new palgrave: a dictionary of Economics.New York: Norton, 1987.

ALCHIAN, Armen A.; DEMSETZ, Harold. Production, information costs, and economic organization. The American EconomicReview, v. 62, n. 5, p. 777- 795, Dec., 1972.

ALLEN, N. J.; MEYER, J. P.The measurement and antecedents of affective, continuance, and normative commitment to the organization.Journal of Occupational Psychology, 63: 1- 18, 1990

ALIANÇA COOPERATIVA INTERNACIONAL (ACI). Princípios cooperativos. Disponível em:

http://www.peaunesco-

sp.com.br/ano_inter/ano_cooperativas/os_principios_alianca_cooperatica_internacional.pdf.

Acesso em: 10 nov 2012.

ALMEIDA, Verônica ScriptoreFerire. A tributação dos Trusts. Biblioteca Nacional de Portugal. ISBN 978-972-40-3447-9. Coimbra: 2009.

ARANZADI, Dionisio. La empresa cooperativa desde la experiência de euskadi. Anuário de Estudios Cooperativos, Bilbau (Espanha): Universidade de Deusto, 1987.

ASSAF NETO, Alexandre. Finanças corporativas e valor. 4a . Ed. São Paulo: Atlas, 2009.

BANCO CENTRAL DO BRASIL. Resolução $\mathrm{n}^{0}$ 3.239. Disponível em $<$ http://www.bcb.gov.br/pre/normativos/res/2004/pdf/res_3239_v1_O.pdf $>$. Acesso em 15 set. 2013.

BANCO CENTRAL DO BRASIL. Manual de Crédito Rural. Disponível em: $<$ http://www4.bcb.gov.br/NXT/gateway.dll? $\mathrm{f}=$ templates \& $\mathrm{fn}=$ default.htm\&vid=nmsGeropMC R:idvGeropMCR > . Acesso em: 2 dez 2011.

BARNEY, Jay e HANSEN, Mark H. Trustworthiness as a source of competitive advantage.Strategic Management Journal, vol. 1, p. 175-190, 1994.

BARTON, D. G. What is a cooperative? In: COBIA, D. W. (Ed.). Cooperatives in agriculture.New Jersey: Prentice- Hall, 1989. p. 1-20.

BELBELLO, Edmondoet al. II bilancio dele societàcooperative. Franco AngeliTextbook Franco. Milano, Italy: 2011.

BEVERLAND, M. B.; LINDGREEN, A. Implementing market orientation in industrial firms: a multiple case study. Industrial Marketing Management, New York, v. 36, n. 4, p. 430-442, 2007. 
BESANKO, David et al. A economia da estratégia. Trad. Bazan Tecnologia e Linguística. $3^{\text {a }}$ ed. Porto Alegre: Bookman, 2006.

BHUYAN e LEISTRITZ (2001) An examination of characteristics and determinants of success of cooperatives in the non-agricultural sectors.Journal of Cooperatives, 16, p. 45-62.

BHUYAN, SAHJIB (2007). The people factor in cooperatives: na analysis of member attitudes and behavior. Canadian Journal of Agricultural Economics, 55, p. 275-298.

BIALOSKORSKI NETO, Sigismundo. Agribusiness cooperativo: economia, doutrina e estratégias de gestão. Dissertação de mestrado - Escola Superior de Agricultura Luiz de Queiroz - ESALQ, Universidade de São Paulo, Piracicaba, 1994. 135p.

.Agribusiness cooperativo: a questão do capital nas empresas de trabalho. Revista Preços Agrícolas, 118: 11-13, 1996.

. Gestão do agribusiness cooperativo. In: Gestão Agroindustrial. Vol.1. BATALHA, M.O. (COORD.), Editora Atlas, São Paulo, 1997.

Cooperativas: Economia, Crescimento e Estrutura de Capital. Tese de doutorado - Escola Superior de Agricultura Luiz de Queiroz - ESALQ, Universidade de São Paulo, Piracicaba, 1998.

. NEVES, E.M.; MARQUES, P.V. Agribusiness cooperativo, eficiência e princípios doutrinários.Revista de Economia e Sociologia Rural,33: 85-121, 1995: UFSC, 2005.

. Economia e gestão de organizações cooperativas. $2^{\text {a }}$ ed. São Paulo: Atlas, 2012.

BIJMAN, J.; HENDRIKSE, G.; OIJEN, A. van.Accommodating two worlds in one organization: changing board models in agricultural cooperatives. Managerial and Decision Economics, Chichester, v. 34, n, 3-5, p. 204- 217, 2013.

BLACK, T. Doing quantitative research in the social sciences: an integrated approach to research design, measurement and statistics. New York: Sage, 1999.

BLAU, G. Testing for a four-dimensional structure of occupational commitment. Journal of Occupational and Organizational Psychology, 76: 469-488. 2003.

BONI, Valdete; QUARESMA, Sílvia Jurema. Aprendendo a entrevistar: como fazer uma entrevista em Ciências Sociais. Em tese, v.2, n.1, jan/jul 2005. Disponível em: http:www.emtese.ufsc.br/3_art5.pdf. Acesso em: 12,Nov 2013.

BRAGA, Eugênio Carlos Ferreira. Entre fatos e discursos: sobre o debate em torno da convergência técnico-metodológica. Revista Brasileira de Informação Bibliográfica em Ciências Sociais (BIB), São Paulo, nº 64, 2007.

BRASIL, Lei $\mathrm{n}^{\mathrm{o}}$ 5.764, de 16 de dezembro de 1971. Define a Política Nacional de Cooperativismo, institui o regime jurídico das sociedades cooperativas, e dá outras providências. Diário Oficial da República Federativa do Brasil, Brasília, DF, 16 dez. 1971. Disponível em: <http://www.planalto.gov.br/ccivil_03/Leis/L5764.htm>. Acesso em: 12nov 2012. 
Lei $\mathrm{n}^{0}$ 6.404, de 15 de dezembro de 1976. Dispõe sobre as sociedades anônimas. Diário Oficial da República Federativa do Brasil, Brasília, DF, 17 dez 1976. Disponível em: http://www.planalto.gov.br/ccivil_03/leis/L6404consol.htm>. Acesso em: 12 Nov 2012.

. Medida Provisória $n^{0}$ 1.961-25, de 25 de agosto de 2000. Dispõe sobre o Programa de Revitalização de Cooperativas de Produção Agropecuária - RECOOP, autoriza a criação do Serviço Nacional de Aprendizagem do Cooperativismo - SESCOOP, e dá outras providências.http://www.planalto.gov.br/ccivil_03/leis/L6404consol.htm>. Acesso em: 24 Nov 2014.

Lei $\mathrm{n}^{\circ}$ 10.406, de 10 de janeiro de 2002. Institui o Código Civil. Diário Oficial da República Federativa do Brasil, Brasília, DF, 11 jan 2002. Disponível em: $<$ http://www.planalto.gov.br/ccivil_03/Leis/2002/L10406.htm>. Acesso em: 12Nov de 2012.

Lei $\mathrm{n}^{\mathrm{o}} 11.638$, de 28 de dezembro de 2007. Altera e revoga dispositivos da Lei no 6.404, de 15 de dezembro de 1976, e da Lei $\mathrm{n}^{\circ}$ 6.385, de 7 de dezembro de 1976, e estende às sociedades de grande porte disposições relativas à elaboração e divulgação de demonstrações financeiras. Diário Oficial da República Federativa do Brasil, Brasília, DF, 28 dez 2007. Disponível em <http:/www.planalto.gov.br/ccivil_03/_ato2007-2010/2007/lei/111638.htm>. Acesso em: 12 Nov 2012.

. Lei $\mathrm{n}^{0} 11.941$, de 27 de maio de 2009. Altera legislação societária. Diário Oficial da República Federativa do Brasil, Brasília, DF, 28 maio 2009. Disponível em http://www.planalto.gov.br/ccivil_03/_ato2007-2010/2009/lei/111941.htm. Acessoem: 12 Nov 2012.

BRITO, C.M. Towards an institutional theory of the dynamics of industrial network.Journal of Business \& Industrial Marketing, v.16, n.3, p.150-66, 2001.

CARMINES, E.G.; ZELLER, R.A. Reliability and validity assessment.Beverly Hills, CA: Sage Publications, Inc. Séries: Quantitative Applications in Social Sciences, v. 17, 1988.

CAVALLI, Cássio. Empresa, direito e economia. Rio de Janeiro: Forense, 2013.

CECHIN, Andrei. Cooperativas brasileiras nos mercados agroalimentares contemporâneos. Imites e perspectivas. In: $O$ mundo rural no Brasil do século 21: a formação de um novo padrão agrário. Buainain, Antônio Marcio, et al (2014). Brasília - DF: Embrapa, 2014.

CHADDAD, Fabio R.; COOK, Michael L. Understanding new cooperative models: an ownership-control rights typology. Review of Agricultural Economics, v. 26, n. 3, p.348-60, 2004.

CHADDAD, F.; ILIOPOULOS, C. Control rights, governance, and the costs of ownership in agricultural cooperatives. Agribusiness: an International Journal, New York, v. 29, n. 1, p. 322, 2013.

CHEUNG, Steven N. S. A theory of share tenancy. Chicago: University of Chicago Press, 1969. 
CHILD, John e FAULKNER, David. Strategies of co-operation: Managing Aliances, Networks, and Join Ventures. Oxford University Press, 1998.COASE, R.H. The nature of the firm.Economic, n. 4, p.386-405, nov. 1937.

. The problem of Social Cost.Journal of Law and Economics, 3, nº 1- 44, 1960.

COASE, RH. The institutional structure of production.Nobel Lecture.The Nobel Foundation, 1991.

COHEN, Morris; NAGEL, Ernest. Introdución a la lógica y al método científico. 2. ed. Buenos Aires: Amarrortu, 1971, 2v.

CONSELHO FEDERAL DE CONTABILIDADE, Resolução $n^{\circ}$ 920, de 19 de dezembro de 2001. Aprova Da NBC Dos Aspectos contábeis específicos em entidades diversas, o item: NBC T 10.8 - Entidades Cooperativas. Brasília (DF) 19 dezembro 2001. Disponível em http://www2.cfc.org.br/sisweb/sre/detalhes_sre.aspx?codigo=2001/00920. Acesso em: 14 dez. 2012.

. Resolução $\mathrm{n}^{\mathrm{o}}$ 959, de 14 de março de 2003. Aprova a NBC $\mathbf{1 0 . 2 1}$ - IT2 Regulamentação do Item 10.21.4 - Demonstração de Sobras e Perdas. Brasília (DF) 14 março 2003. Disponível em http://www2.cfc.org.br/sisweb/sre/detalhes_sre.aspx?codigo=2001/00959. Acesso em: 14 dez 2012.

Resolução CFC n ${ }^{0} 1.121$, de 2008 - NBCT 1 - Estrutura Conceitual para a Elaboração e Apresentação das Demonstrações Contábeis. Brasília (DF) 4 de abril de 2008. Disponível em:http://www2.cfc.org.br/sisweb/sre/detalhes_sre.aspx?cod=2009/001151. Acesso em: 14 dez. 2012.

. Resolução $n^{0} 1.151$, de 23 de janeiro de 2009. Aprova NBC TG 12 -Ajuste a valor presente. Brasília (DF) 23 janeiro 2009. Disponível em http://www2.cfc.org.br/sisweb/sre/detalhes_sre.aspx?cod=2009/001151. Acesso em: 14 dez. 2012.

. Resolução $n^{0} 1.153$, de 23 de janeiro de 2009. Aprova NBC TG 19.19 Instrumentos financeiros: reconhecimento, mensuração e evidenciação. Brasília (DF) 23 janeiro $2009 . \quad$ Disponível em http://www2.cfc.org.br/sisweb/sre/detalhes_sre.aspx?cod=2009/001153. Acesso em: 14 dez. 2012.

. Resolução $n^{0} 1.305$, de 25 de novembro de 2010. Aprova NBC TG 07 -Subvenção e assistência governamentais. Brasília (DF) 25 novembro 2010. Disponível em http://www2.cfc.org.br/sisweb/sre/detalhes_sre.aspx?cod=2010/001305. Acessoem: 14 Dez 2012.

COOK, Michel. L.; CHADDAD, F. R.; ILIOPOULOS, C. Advance in cooperatives theory since 1990: a review of agricultural economic literature. In HENDRIKSEN, G.W.J. (org.).Restructuring agricultural cooperatives. Amsterdam: Editora, 2004. p. 65-90.

.The Role of Management Behavior in Agricultural Cooperatives.Journal of Agriculture Cooperatives, Vol. 9, 1994. 
The future of U.S. agricultural cooperatives: a neo-institutional approach. American Journal Agricultural Economy, n. 77, p. 1153-1159, 1995a.

COOK, Michel L.; ILIOPOULOS, C. The future of U.S. agricultural cooperatives: a neoinstitutional approach. American Journal of Agriculture Economics, v. 77, pp. 1153-9, 1995b.

COOPER, Donald R. et al.Métodos de pesquisa em administração. Trad. Luciana de Oliveira Rocha. $7^{\mathrm{a}}$ ed. Porto Alegre: Bookman, 2003.

COOPER-HAMIK, A.; VISWESVARAN, C. The constructofworkcommitment: Testinganintegrative framework. PsychologicalBulletin, 131: 241-259. 2005.

COSTA, Eliud José Pinto da. ICMS Mercantil. São Paulo: QuartierLatin, 2008.

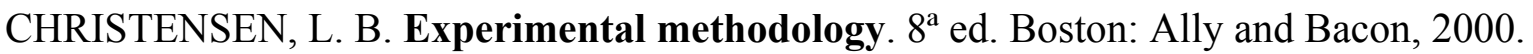

DA COSTA, Fernando Ferreira. Código cooperativo anotado. Anotação ao art. 71, p. 94. Coimbra: Livraria Petrony, 1981.

DEMSETZ, Harold. Toward a Theory of Property Rights.The American Economic Review, Vol. 57, No. 2, Papers and Proceedings of the Seventy-ninth Annual Meeting of the American Economic Association. May, 1967, p. 347-359.

DEMSETZ, Harold. The Structure of Ownership and the Theory of the Firm.Journal of Law and Economics, v. 26, n. 2, p. 375-390, June, 1983.

DEMSETZ, Harold; LEHN, Kenneth.The Structure of Corporate Ownership: Causes and Consequences. The Journal of Political Economy, v. 93, n. 6, p. 1155-1177, Dec., 1998.

DE PLÁCIDO E SILVA. Vocabulário jurídico. 22ª ed. São Paulo: Forense, 2003.

DI DIEGO, Sebastiano. Le società cooperative. IV ed.Roma: Maggioli, 2011.

DOMINGUES, Tarso et al. Estudos de direito das sociedades. Coimbra: Almedina, 2007.

DUARTE, Rosália. Entrevista em pesquisas qualitativas. Educar em Revista. Curitiba, nº 24 , de 2004.

DYER, Jeffrey; CHU, Wujin.The Role of Trustworthiness in Reducing Transaction Costs and Improving Performance: Empirical Evidence from the United State, Japan and Korea. Organization Science, v. 14 n. 1, january-february 2003, p.57-68, 2003.

ESCHENBURG, Rolf. Una breve introducción a la teoria económica de lacooperación. Perspectiva Econômica. São Leopoldo, v. 13, p. 7-14, 1983.

EISENHARDT, K. M. Building theories from case study research. The Academy of Management Review.v. 14, n. 4, p. 532-550, 1989.

FARINA, Elizabeth M. M. Q. et al.Competitividade: mercado, estado e organizações.São Paulo: Singular, 1997. 
FERRAZ, J.C; KUPFER, D.; HAGUENAUER, L. Made in Brazil: desafios competitivos para a indústria. Rio de Janeiro: Campus, 1995.

FULTON, M. E. The future of Canadian agricultural cooperatives: a property rights approach. American JournalofAgriculturalEconomics, v. 77, p. 1144 -1152, 1995.

FUSCO,J.P.A. Cadeias de fornecimento e redes de empresas: abordagem metodológica para avaliação de competitividade. São Paulo: Arte e Ciência, 2004.

FRANKE, Valmor. Direito das sociedades cooperativas. São Paulo: Edusp, 1973.

GASSNER, Wolfgang. The influence of tax principles on the taxation of income from capital: A response. In: ESSERS, Peter; RIJKERS, Arie (orgs.). The notion of income from capital. Amsterdam: IBFD, 2005, pp. 33-52.

GILLIES, R. Cooperative Learning - integrating theory and practice. The University of Queensland. California: Sage Publications, Inc. 2007.

GINTIS, Herbert et al. Moral sentiments and material interest: the foundations of cooperation in economic life. Massachusetts: Massachusetts of technology, 2005.

GIORGI, Maurizio; VACIAGO, Giuseppe.Le società cooperative.Tipi di cooperative strumenti di tutela, aspectticivili, concorsuall, tributari e penali.Roma: Antonio Millani, 2011.

GRANOVETTER, Mark. Economic action and social structure: the problem of embeddedness. American Journal of Sociology, v.91, p.481-510, 1985.

GRAZIANO DA SILVA, J. Impactos das tecnologias da informação na agricultura. Revista de Economia e Sociologia Rural, v. 34, p. 7-30, nov./dez.1995.

HANEKOM et. al. IFRS 2012. Interpretação e aplicação. Equipe da KPMG no Brasil. Porto Alegre: Bookman, 2013.

HANSMANN, Henry (1996). The ownership of enterprise. The Belknap Press of Harvard University Press.

HANSMANN, Henry. Ownership of the firm.Journal of Law, Economics \& Organization, v. 4, n. 2, p. 267-304, 1988.

HARRISON, B. Industrial district: oldwines in new bottles?. Regional Studies, v. 26, n. 5, p. 469-481, 1991.

HARSANYI, John. Rational-Choice Models of Political Behavior vs. Functionalist and Conformist Theories. World Politics, v. 21, n. 4, p. 513-38, jul. 1969.

HESS, M. Spacialrelationships? Towards a reconceptualizationofembeddedness. Progress in HumanGeography, v. 28, n. 2, p.165-186, 2003.

HENDRIKSE, G.W.J. Cooperatives and financial structure.Tilburg University. (1993) Disponível

em: $<$ http://www.fondazionebarberini.it/allegati/HendrikseVeerman_1995_110125011611.pdf $>$. Acessoem: 12nov. 2012. 
. On the co-existence of spot and contract markets: the delivery requirement as contract externality. European Review of Agricultural Economics, Amsterdam, v. 34, n. 2, p. 257-282, 2007.

HOLMES, Kevin. The concept of income.A multi-disciplinary analysis. The Netherlands, IBFD Publications BV, 2001.

HOUAISS, Antônio. Dicionário Houaiss da língua portuguesa. Rio de Janeiro: Objetiva, 2004.

HUMAN, Sherrie E. e PROVAN, Keith G.An emergent theory of structure and outcomes in small-firm strategic manufacturing network.Academy of Management Journal, p.368$403,1997$.

IUDÍCIBUS, Sérgio; MARTINS, Eliseu. Uma investigação e uma proposição sobre o conceito e o uso do valor justo. Revista de Contabilidade e Finanças,edição de 30 anos de Doutorado, p. 9-18, 2007.

IUDÍCIBUS, Sérgio et al. Manual de contabilidade societária. São Paulo: Atlas, 2010.

JARILLO, C. J. Strategic Networks: CreatingtheBorderlessOrganization. Butterworth. InternationalConsiderations, 1998.

JOHNSON, David W. JOHNSON, Roger T. STANNE, Mary Beth. Cooperative_Learning_Methods_A_Meta_Analysis_Cooperative_Learning_Methods_A_Met a-Analysis.Disponível em: $<$ https://www.academia.edu/5206954/EXHIBIT_B_>. Acesso em 20 nov. de 2014.

KERLINGER, Fred N. Foundations of behavioral research. 2. Ed. New York: Holt, Rinehart and Winston, 1973.

KERLINGER, Fred N. Metodologia da pesquisa em ciências sociais: um tratamento conceitual. São Paulo: EPU: Edusp, 1980.

KLEIN, H. J.; MOLlOY, J. C.; COOPER, J. T. Conceptual foundations: Constructdefinitionsandtheoreticalrepresentationsofworkplacecommitment. In H. J. Klein, T. Becker, \& J. P. Meyer (Eds.), Commitment in organizations: Accumulatedwisdomand new directions. London: Routledge/Taylor \& Francis. 2009.

KNIGHT, G. P. et al. Information process ingand the development of cooperative, competitive, and individualistic social values. DevelopmentalPsychology, v.21, n.1, p.37-45, 1985.

KOZA, Mitchell P. and LEWIN, Arie Y. The Co-evolution of Strategic Alliances.Organization Science, v. 9, n. 3, p. 255-264, 1998.

KRUEGER, G. Cooperativismo e o novo Código Civil. Belo Horizonte: Mandamentos, 2003. 223p. 
LAKATOS, Eva Maria. MARCONI. Marina de Andrade. Metodologia científica. $5^{\text {a }}$ ed. São Paulo: Atlas, 2009.

LAVILLE, Christian; DIONNE, Jean. A construção do saber: manual de metodologia da pesquisa em ciências humanas. Belo Horizonte: UFMG, 1999.

LEATHERS, HOWARD (2006) Are cooperatives efficient when membership is voluntary?Journal of Agricultural and Resource Economics, Western Agricultural Economics Association, 31, vol 3, p. 667-676.

LIMA, Reginaldo Ferreira. Direito cooperativa tributário. São Paulo: Max Limonad, 1997.

LYLES, Marjorie A. Fleury, Maria Tereza Leme e Oliveira Junior, Moacir de Miranda (Coord). In: Gestão estratégica do conhecimento: integrando aprendizagem, conhecimento e competência. 1. ed. São Paulo: Atlas, 2010.

LOPES DE SÁ, Antônio. Dicionário de contabilidade. 9. ed. São Paulo: Atlas, 1995.

MAGRETTA, Joan. Entendendo Michael Porter: o guia essencial da competição e estratégia. Tradução Carlos Szlak. São Paulo: HSM Editora, 2012.

MAILHIOT, GÉRALD B. Dinâmica e gênese dos grupos: atualidades das descobertas de Kurt Lewin. 2.ed. São Paulo: Livraria Duas Cidades, 1973.

MATHIEU, J. E.; ZAJAC, D. M. A reviewand meta-analysisoftheantecedents, correlates, andconsequencesoforganizationalcommitment. PsychologicalBulletin, 108: 171-194. 1990.

MANN, Peter. Métodos de investigação sociológica. Rio de Janeiro: Zahar, 1983.

MEM, Devair Antônio. Normas brasileiras de contabilidade para sociedades cooperativas: um expressivo avanço aos anseios cooperativistas. OCEPAR, abr. 2006. Disponível: http://www.ocepar.org.br/UPL/Outro/ArtigoNBCTCompleto2.pdf. Acesso em: 15 abr 2012.

MENDES, Judas Tadeu Grassi; PADILHA JUNIOR, João Batista. Agronegócio: uma abordagem econômica. São Paulo: Pearson Prentice Hall, 2007.

MENARD, C.; A new institutional approach to organization. In: MENARD, C.; SHIRLEY,M. M. (ed.).Handbook of New Institutional Economics. Springer: p.p. 281-318. 2005.

MEYER, J. P. Commitment in a Changing World of Work. In H. J. Klein, T. Becker, \& J. P. Meyer (Eds.), Commitment in organizations: Accumulated wisdom and new directions. London: Routledge/Taylor \& Francis. 2009.

MEYER, J. P., STANLEY, D. J., HERSCOVITCH, L., TOPOLNYTSKY, L. Affective, continuance, and normative commitment to the organization: A meta-analysis of antecedents, correlates, and consequences. Journal of Vocational Behavior, 61: 20-52. 2002.

MINTZBERG, Henry [et al.]. O processo da estratégia: conceitos, contextoe casos selecionados. Tradução Luciana de Oliveira da Rocha. 4a . Ed. Porto Alegre: Bookman, 2006. 
MOWDAY, R. T., STEERS, R. M., PORTER, L. W. The measurement of organizational commitment.Journal of Vocational Behavior, 14: 224-227. 1979

NAMORADO, Rui. Introdução ao direito cooperativo. Coimbra: Livraria Almedina, 2000.

NASCIMENTO, Fernando Rios do. Cooperativismo como alternativa de mudança. Rio de Janeiro: Forense, 2000.

NASSAR, André M.; ZYLBERSZTAJN, Decio. Associações de interesse no agronegócio brasileiro: análise das estratégias coletivas. Revista de Administração, n $^{\circ}$ 39, nº 2, 2004.

NEISSER, U. Cognition and Reality, Ed. W.H. Freeman, San Francisco. 1976.

NOOTEBOOM, B. Inter-firmalliances: Analysisand Design. Routledge: London, 1999.

NORTH, D. C. Institutions, institutional change and economic performance. Cambridge: Cambridge University Press, 1990.

NORTH, D. C. Institutions.Journal of Economic Perspective, v.5, p.97-112, Winter, 1991.

OFFICE OF TECHNOLOGY ASSESSMENT.A new era for American Agriculture.U.S. Government Printing Office, Washington, D. C., 1992.

OLSON, Mancur. The logic of collective action: public goods and theory of groups. Cambridge: Harvard University Press, 1965.

OLSON, Mancur. A lógica da ação coletiva. Trad. Fabio Fernandes. São Paulo: Edusp, 1999.

OSTROM, Elinor. Collective Action and Local Development Processes. Bologna:Sociologica, 2007.

OSTROM, Elinor. Governing the commons: the evolution of Institutions for collective action. Cambridge: 1990.

PANICO, Paolo. La FunzionedelTrustee in Italia. Il TrustnelDiritto dele Persone e dela Famiglia, Milano, 2003. p. 76.

PARKIN, Michael. Economia. Tradução Cristina Yamagami; revisão técnica Nelson

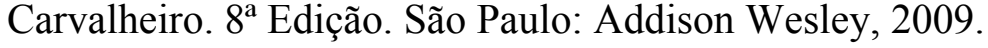

PINDYCK, Robert S., RUBINFELD, Daniel L. Microeconomia. $7^{\text {a }}$ ed. São Paulo: Person Education do Brasil, 2010.

PINHEIRO, Armando Castelar; SADDI Jairo. Direito, economia e mercado. Rio de Janeiro: Elsevier, 2005.

PINHO, Diva B. Presidente do Comitê OCB de Gênero em Cooperativas - Tradução e adaptação de publicações de divulgação da ACI, 1995. Disponível em: <http: www.itcp.usp.br/drupal/node/209>. Acesso em: 20 abr. 2012.

PORTER, Michael. Vantagem competitiva: criando e sustentando um desempenho superior. Rio de Janeiro: Elsevier, 1989. 
PORTER, M. E. Competição/OnCompetition.Tradução de Afonso da Cunha Serra. ed. rev. amp. Rio de Janeiro. Elsevier, 2009.

ROJAS, Ricardo Arturo Osorio. El cuestionario. 2001. Disponível em: $<$ http://www.nodo50.org/sindpitagoras/Likert.htm>. Acesso em 18 nov de 2013.

SACHS, Ignacy. Inclusão social pelo trabalho: desenvolvimento humano, trabalho decente e o futuro dos empreendedores de pequeno porte. Rio de Janeiro: Garamond, 2003.

SAMPIERI, Roberto Hernández et al. Metodologia de pesquisa. $3^{\text {a }}$ ed. São Paulo: McGrawHill, 2006.

SANDLER, Todd. Collective Action: Theory and Applications. Michigan: Michigan University Press, 1995.

SANDRONI, Paulo. Dicionário de economia do século XXI. Rio de Janeiro: Record, 2005.

SAKO, Mari. Does Trust Improve Business Performance? In: Bachmann, R. e Lane, C. (Orgs). Trust within and between organization. Oxford University Press, p.88-117, 1998.

SELLTIZ, C. et al. Métodos de pesquisa nas relações sociais. 3. ed. São Paulo: Herder/Edusp, 1967.

SLACK, N. ; CHAMBERS, S.; HARLAND, C. A administração da produção. São Paulo: Atlas, 1997.

SPEIDEL, R. Article 2 and relational sales contracts.Loyola of Los Angeles Law Review, 26, abr. 1993, p. 789-810.

SILVA, Tania Nunes; PEDROZO, Eugenio Avila. (Orgs); ESTIVALETE, Vânia F.B; BEGNIS, Heron S. M; BARATA, Tiago S.; JARDIM, Paulo Antonio M.; JERÔNIMO, Fátima B.; MARASCHIM, Angela F.; PASQUAL, Cássia A.; SILVEIRA, Helena S. Relações de Cooperação e ConfiançaemOrganizaçõesCooperativasPromovendo Capital Social. III Encontro de Investigadores Latino-Americanos de Cooperativismo, São Leopoldo: UNISSINOS - Working Paper, 2004.

SHMIZU. R. The Growth of firms in Japan. Tokyo: Keio Tsushin, 1980.

STAATZ, John M. The structural characteristics of farmers cooperatives and their behavioral consequences. Washington, D.C.: Unite Estates Department of Agriculture (USDA), 1987, 28p. Disponível em: <http://www.rurdev.usda.gov/rbs/pub/sr18/strcture.pdf $>$ Acesso em: 30 nov 2011.

SZTAJN, Raquel et al. Economia dos contratos. In: SZTAJN, Raquel, ZYLBERSZTAJN, Decio (orgs.). Direito e economia: análise econômica do direito e das organizações. Rio de Janeiro: Elsevier, 2005.

STOBERL, Paulo Roberto. Ato cooperativo nos ramos do cooperativismo: Ramo agropecuário. In: Ato cooperativo. KRUEGER, Guilherme (Coord.). Belo Horizonte: Mandamentos, 2004. 
THOMPSON, Artur A. [et al.]. Administração estratégica. Tradução Roberto Galman, Katia Aparecida Roque. São Paulo: McGraw-Hill, 2008.

TROESTER, Roberto Luís. Introdução à microeconomia. In: Manual de Economia.Organizadores Diva Benevides, Marco Antônio Sandoval de Vasconcelos e RudneiToneto Jr. 5 ed. São Paulo: Saraiva, 2004.

TRIVIÑOS, A. N. S. Introdução à pesquisa em ciências sociais: a pesquisa qualitativa em educação. São Paulo: 1987.

VITALIANO, Peter. An Alternative Conceptual Basis for Analyzing a Complex Institution.American Journal of Agricultural Economics, v. 65, n. 5, p. 1078-1083, Dec., 1983.

WAACK, Roberto Silva; MACHADO FILHO, Claudio Pinheiro; Administração estratégica em cooperativas agroindustriais. 1999. Disponível em <http:// http://www.fearp.usp.br/egna/arquivo/13.pdf>. Acesso em: 24 nov. 2014.

WILLIAMSON, O. E.The economic institutions of capitalism. New York: Free Press, 1985.

Comparative economic organization: the analysis of discrete structural alternatives. Administrative Science Quarterly, 1991.

As instituições econômicas do capitalismo: firmas, mercados, relações contratuais. São Paulo: Pezco, 2012.

WILLIAMSON, O. E. WINTER, S. G. The nature of the firm: origins, evolution, and development. Oxford University Press, 1993.

WILLIAMSON, O. E.The mechanisms of governance. New York: Oxford University Press, 1996.

YIN, Robert K. Estudo de caso: planejamento e métodos. Trad. Ana Thorell; ver.téc. Cláudio Damacena. $4^{\mathrm{a}}$ ed. Porto Alegre: Bookman, 2010.

ZYLBERSZTAJN, Decio. Organizational challenges for farmers cooperatives." In: Symposium of the International Agribusiness Management Association. San Francisco, CA, 1993.

Administração, 29(3): 23-32, 1994.

Organização de cooperativas: desafios e tendências. Revista de

.Entre o mercado e a hierarquia: análise de casos de quebra contratual no agribusiness. Série Estudos Temáticos n.1, Pensa-FEA/USP, 1996.

ZUCKER, Lynne G. Productionoftrust: institucional sourcesofeconomicstruture, 1840-1920. Research in OrganizationalBehavior, v. 08, p. 53-111, 1986. 


\section{APÊNDICE 1 - Roteiro de entrevista para técnicos especializados}

\begin{tabular}{|c|c|}
\hline Organização: & Localidade: \\
\hline Nome: & E-mail: \\
\hline Cargo: & Fone: \\
\hline \multicolumn{2}{|c|}{$\begin{array}{l}\text { Introdução: } \\
\text { Descrição geral do projeto (propósito, participantes escolhidos, motivo pelo qual foram } \\
\text { selecionados, utilização dos dados obtidos) }\end{array}$} \\
\hline $\begin{array}{l}\text { Característica } \\
\text { Confidencialid }\end{array}$ & a entrevista \\
\hline
\end{tabular}

1. A sociedade cooperativa de produção agropecuária tem como escopo a solidariedade social e a comunhão de interesses comuns? Efetivamente, a finalidade principal da organização é a prestação de serviços aos seus cooperados? Em caso positivo, o ambiente econômico desenvolvido propõe uma justa e equitativa distribuição da riqueza produzida aos cooperados produtores rurais?

2. Quais os produtos comercializados para os mercados interno e externo? Em que nível de valores agregados (industrialização) são comercializados?

3. Para atingir os objetivos contratualmente, como a sociedade cooperativa utiliza a combinação de fatores de produção, com o fim de obter os produtos e serviços e a racionalidade econômica, para que se efetive o máximo de produto com os recursos limitados e o equilíbrio financeiro?

4. Como o modelo cooperativo adotado pela sociedade cooperativa pode promover o ganho direto aos cooperados? Qual (is) a (s) forma (s) utilizada (s) pela organização para proporcionar o ganho indireto não financeiro ao cooperado? É percebível a melhoria econômica e não-econômica do cooperado produtor rural?

5. A sociedade cooperativa identifica no cooperado, a educação e as informações qualificadas necessárias, para que a cooperação atinja estágios importantes no desenvolvimento da organização? Ela tem permitido o crescimento individual do cooperado por meio da união de interesses com a atuação econômica?

6. Na sociedade cooperativa, o instituto cooperação está diretamente envolvido nas relações contratuais entre os cooperados? Quais as razões que justificam a formação de cooperação entre os cooperados? O exercício da cooperação tem como propósito unicamente o benefício financeiro?

7. A cooperação apresenta vantagens e desvantagens econômicas. Quais as principais vantagens oportunizadas aos cooperados integrantes da organização?

8. Quais os desafios do trabalho coletivo, quando os cooperados não são atores e conseguem aproveitar de alguns dos benefícios da coletividade na organização cooperativa?

9. O modelo societário cooperativo tem-se considerado eficiente, econômico e socialmente, resultando em vantagens maiores que os custos da renúncia a uma condição de livre mercado?

10. Existem outras relações contratuais entre a sociedade cooperativa e o cooperado? Quais as características dessas relações contratuais (formais/informais)?

11. A influência de grande número de cooperados na organização pode motivar menos 
eficiência do que os grupos com menos integrantes. Neste caso, a sociedade cooperativa considera prejudicial a participação social de cada cooperado, por motivar o aumento de custo da própria governança? Na formação dos grupos de cooperados identifica a presença de aproveitadores?

12. Em termos práticos, o papel da sociedade cooperativa está em organizar o ambiente de negócio, reduzir as incertezas e, em conjunto com outros instrumentos econômicos, definir um conjunto possível de escolhas, criando um ambiente favorável para o processo de tomada de decisão. Quais as principais ações realizadas para criação de um processo de tomada de decisão?

13. A sociedade cooperativa tem consciência de que há um direito comum de propriedade entre os cooperados? Quais são esses direitos?

14. A escrituração comercial da sociedade cooperativa permite a divisão da apuração do resultado do exercício em: (i) ato cooperativo correspondente aos ingressos diminuídos dos dispêndios; (ii) ato não cooperativo vinculando as receitas e diminuídas dos custos de despesas?

15. Qual da capacidade da sociedade cooperativa possui para gerar resultados positivos no período, e nos próximos anos, de forma gradual, segura e rentável, auto-sustentando suas atividades operacionais e proporcionado ganho aos cooperados?

16. O art. 28 da Lei $n^{0}$ 5.764, de 1971, prevê a criação do Fundo de Assistência Técnica, Educacional e Social (Fates), cuja origem decorre dos princípios dos pioneiros de Rochdale: "dos ganhos, uma parcela seria destinada a um fundo para educação dos membros cooperados." A sociedade cooperativa constitui anualmente o Fates? Além da parcela das sobras líquidas, qual(is) o(s) valor(es) que integra(m) o Fates?

17. Na hipótese de a sociedade cooperativa não possuir capacidade econômica e financeira, para gerar anualmente resultado positivo, sob a forma de sobras líquidas, e/ou não destina esse valor, qual a sistemática de apuração de ganhos classificados como indiretos que são transferidos aos cooperados?

18. Como a sociedade cooperativa deve gerar, por meio de provimento de uma rede de segurança, as condições necessárias para que o cooperado possa obter a continuidade a geração de renda, nas operações inerentes à exploração de sua atividade rural? Como proporcionar condições favoráveis para o cooperado possa auferir os ganhos indiretos?

19. Quais as principais falhas no ambiente institucional (leis, normas, entre outras) que implicam restrições ao desenvolvimento da atividade econômica da organização cooperativa em detrimento de maior ganho ao cooperado?

20. Quais as principais redes formais produtivas consideradas ideais a ponto de vista da coordenação dos negócios envolvendo a ação conjunta com o cooperado pessoa física? Há redes produtivas informais que possam ser identificadas no processo de integração cooperado e sociedade cooperativa de produção agropecuária? 


\section{APÊNDICE 2 - Questionário aplicado a cooperados pessoa física}

\begin{tabular}{|l|l|}
\hline Nome: & Localidade: \\
\hline Fone: & E-mail: \\
\hline
\end{tabular}

1. Qual a atividade principal?

(Produção de soja, arroz, milho, uva, frango, suínos, etc.)

2. Qual o grau de escolaridade?

\begin{tabular}{|l|l|}
\hline () Ensino fundamental incompleto & () Ensino Superior \\
() Ensino fundamental completo & () Nível de Especialização \\
() Ensino médio incompleto & () Nível de Mestrado \\
() Ensino médio completo & () Nível de Doutorado \\
\hline
\end{tabular}

3. Qual a localização da propriedade?

(Distrito, Município)

4. Quantas pessoas integram a força de trabalho na propriedade explorada?

Números de Membros da Família:

Números de Empregados Fixos:

Números de Empregados Temporários:

5. Quantas pessoas (unidade familiar) são beneficiadas com a renda da propriedade?

() Até 4 (quatro) pessoas

() Até 6 (seis) pessoas

() Até $10(\mathrm{dez})$ pessoas

() Mais de 10 (dez) pessoas

6. A sociedade cooperativa é uma organização de pessoas, com forma e natureza jurídica próprias, constituída com a finalidade para prestar serviços para o cooperado. Quais os principais de serviços que são oferecidos aos cooperados?

() Apenas os serviços de intermediação de produção do cooperado

() Serviços de assistências técnicas e especializados em extensão rural

() Serviços de industrialização da produção do cooperado

() Serviços de assistência social, educativa e profissional

() Serviços de assistência jurídica e empresarial

() Serviços de créditos e financiamento agropecuário

() Serviços de transportes e armazenagens da produção

() Serviços de cotação de produto na bolsa de mercadorias

() Vendas de insumos, combustíveis, máquinas e equipamentos

() Outros

7. O cooperativismo possui legislação específica que regula várias atividades formais que se estabelecem entre o cooperado e a sociedade cooperativa. Qual (is) a(s) principal (is) matéria(s) que é (são) regulada(s) pelos atos legais e normativos de seu conhecimento?

() Ingresso e saída do cooperado na sociedade cooperativa

() Estatuto social da sociedade cooperativa

() Capital social da sociedade cooperativa

() Conselho fiscal

() Distribuição de despesas 
() Distribuição das sobras líquidas

() Outras

8. Na condição de cooperado, o Sr.(a) participa das assembleias promovidas pela sociedade cooperativa?

() Nunca participei das assembleias

() Sempre participei das assembleias anualmente

() Sempre participei das assembleias para decisões e aprovações de investimentos

() Sempre participei das assembleias da distribuição das sobras ou perdas líquidas

() Sempre participei de todas as assembleias, inclusive, as extraordinárias

9. Qual(is) as razão (ões) que levou (aram) a integrar, como cooperado, o quadro societário da sociedade cooperativa?

() Acesso a informações econômica e o comportamento do mercado

() Assistência técnica e extensão rural

() Auxílio econômico e financeiro na exploração da atividade

() Oportunidade de mercado para a comercialização dos produtos

() Acesso a inovações tecnológicas, inclusive, aquisição de insumos

() Segurança em período de crise econômica ou restrição no mercado

() Assistência social, educativa e profissional

() Serviços de transportes e armazenagens da produção

() Outros

10. A ação coletiva (cooperação) entre o cooperado e a sociedade cooperativa tem proporcionado melhores condições para exploração da atividade rural?

() $\operatorname{Sim}()$ Não

Em caso afirmativo: Quais as principais vantagens da cooperação?

() Em cooperação promove a melhoria e incremento da economia individual

() Em cooperação ocorre a troca de experiência com melhorias da produção

() Em cooperação o benefício econômico é maior que o individual e livre mercado

() Em cooperação há respeito às decisões majoritárias e igualitárias de governança

() Em cooperação concilia benefícios sociais e a eficiência econômica

() Em cooperação há conjugação de esforços e de meios da organização

(...) Em cooperação permite a garantia contratual dos negócios realizados

() Em cooperação o resultado econômico da produção será distribuído entre todos

() Outras

11. Há alguma(s) vantagem (ens) em realizar a comercialização da produção por intermédio da sociedade cooperativa?

() $\operatorname{Sim}()$ Não

Em caso afirmativo: Quais as principais vantagens?

() Melhores preços

() Assistência técnica

() Facilidade de negociação da produção

() Assessoria na compra de insumos

() Menor distância para entrega da produção

() Garantia de recebimento do valor da produção comercializada

() Outras 
12. O cooperado é obrigado a cumprir alguma(s) exigência(s) para comercializar a produção por intermédio da sociedade cooperativa?

() $\operatorname{Sim}()$ Não

Em caso afirmativo: Quais?

() Exigência de alta qualidade do produto

() Restrição na utilização de determinados insumos

() Restrição na variedade do produto

() Limite de produção por área explorada

() Limite na entrega da produção previsto em cláusulas contratuais

() Outras

13. Os produtos entregues a sociedade cooperativa sofrem algum processo de beneficiamento e/ou industrialização antes de serem comercializados para o mercado?

() $\operatorname{Sim}()$ Não

Em caso afirmativo: Quais os processos?

() Simples beneficiamento, sem alterar as suas características in natura

() Simples beneficiamento, porém, com alteração das suas características in natura

(...) Industrialização, com baixo valor agregado

() Industrialização, com alto valor agregado

() Não possuo essa informação

14. Qual(is) o(s) destinos dos produtos entregues a sociedade cooperativa?

() Mercado interno

() Mercado externo

() Mercado interno e externo

() Retorno ao cooperado, após industrializados

() Outros

15. Na hipótese de existir contratos de parceria de integração vertical (contrato formal) realizados durante os últimos 5(cinco) anos, houve alguma quebra contratual pela comercialização da produção sem o intermédio da sociedade cooperativa?

() $\operatorname{Sim}()$ Não

Em caso afirmativo:

(i) Quem motivou a quebra contratual? () Cooperado; () Sociedade cooperativa; (ii) Quais os motivos?

() Preço contratado do produto na sociedade cooperativa era menor que o mercado

() O produto oferecido não atendia às condições previstas no contrato

() $\mathrm{O}$ valor da venda do produto era para saldar as dívidas na sociedade cooperativa

() A sociedade cooperativa estava em dificuldades financeiras

() Outras

16. As palavras e expressões utilizadas, como instrumentos de comunicação pela sociedade cooperativa, são integralmente conhecidas e expressam significados familiares (conhecidas)?

() $\operatorname{Sim}()$ Não

Em caso afirmativo: São conhecidas e de significados familiares?

() Ato cooperativo

() Ato não cooperativo

() Sobras e perdas líquidas

() Lucro e Prejuízo Contábil 

() Quota-parte
() Assembleia
() Fundo de Assistência Técnica, Educacional e Social - Fates

17. A sociedade cooperativa ao promover a divulgação das demonstrações financeiras anualmente, esclarece a forma de apuração das sobras ou perdas líquidas?

() $\operatorname{Sim}()$ Não

Em caso afirmativo: As sobras líquidas são distribuídas?

() São distribuídas integralmente aos cooperados

() São distribuídas, porém, com percentual limitado ao pela assembleia anual

() Não há distribuição das sobras líquidas

() As sobras líquidas têm sido capitalizadas para investimentos

() As sobras líquidas são destinadas para formação do Fates

() Outras

18. Em termos percentuais, qual o valor recebido a mais decorrente da comercialização da produção, por intermédio da sociedade cooperativa, em comparação com aquele que seria comercializado por conta própria? (Período de referência: últimos 5 anos)
() Até 5\%
() Até $10 \%$
() Até $20 \%$
() Até 30\%
() Outros.

19. Qual a forma que é disponibilizada a diferença a maior em decorrência da comercialização da produção por intermédio da sociedade cooperativa?
() A diferença integra o valor da Nota Fiscal de Venda da produção
() A diferença é distribuída sob a forma de Sobras Líquidas
() A diferença é retida pela sociedade cooperativa para investimentos
() A diferença é compensada na aquisição de insumos da sociedade cooperativa
() Outra.

20. A sociedade cooperativa tem oportunizado as condições necessárias para que haja aprimoramento técnico, com resultado na melhoria de produtividade da cultura explorada e na criação de animais?
() Sim () Não
Em caso afirmativo: Quais os eventos promovidos?
() Cursos e palestras em temáticas específicas
() Seminários com atividades de extensão rural na propriedade
() Curso de especialização
() Curso de mestrado/doutorado
() Outra.

21. Como são percebidos individualmente os serviços ofertados de forma gratuita pela sociedade cooperativa?
() Pelo aumento do conhecimento técnico e na melhoria da atividade produtiva
() Pelo aumento do bem-estar econômico e social familiar
() Pelo aumento do consumo de bens e serviços
() Pelo aumento no investimento na propriedade explorada
() Pela comparação do nível econômico e social com outros produtores rurais 

() Pela oportunidade de comercialização do produto em outros mercados
() Pela diminuição de gastos com insumos, máquina e equipamentos, entre outros
() Pelo aumento das reservas em poupança e/ou aplicações financeiras
() Outras

22. Os serviços prestados pelas sociedades cooperativas são em sua maioria gratuita, e demonstram que essa condição (gratuita) valoriza as relações de usuário da sociedade cooperativa, mas dificulta um julgamento de valor, quanto ao recebimento desses serviços. Em sua opinião, qual a valorização em reais (aproximado) dos serviços prestados de forma gratuita anualmente?
() Até $\mathrm{R} \$ 6.000,00$
() Acima de $\mathrm{R} \$ 6.000,00$ até $\mathrm{R} \$ 12.000,00$
() Acima de R\$12.000,00 até R\$18.000,00
() Acima de R\$18.000,00 Até 24.000,00
() Acima de R $\$ 24.000,00$

23. A sociedade cooperativa é caracterizada pela prestação de serviços de excelência em benefícios dos cooperados.
1. Concorda muito
2. Concorda
3. Nem concorda e nem discorda
4. Discorda
5. Discorda muito

24. Os serviços prestados de forma gratuita sempre oportunizam ganho na atividade profissional do cooperados.

1. Concorda muito

2. Concorda

3. Nem concorda e nem discorda

4. Discorda

5. Discorda muito

25. O cooperado sempre percebe o ganho decorrente dos serviços prestados de forma gratuita pelo bem-estar familiar ou pelo consumo de bens.

1. Concorda muito

2. Concorda

3. Nem concorda e nem discorda

4. Discorda

5. Discorda muito

26. A sociedade cooperativa sempre informa ao cooperado quais os serviços prestados de forma gratuita.
1. Concorda muito
2. Concorda
3. Nem concorda e nem discorda
4. Discorda
5. Discorda muito

27. A sociedade cooperativa sempre escolhe o cooperado com maior produtividade para ofertar-lhe serviços de forma gratuita. 
1. Concorda muito

2. Concorda

3. Nem concorda e nem discorda

4. Discorda

5. Discorda muito

28. A sociedade cooperativa proporciona ao cooperado a oferta de serviços de forma gratuita decorrente de recursos proveniente do Fates.

1. Concorda muito

2. Concorda

3. Nem concorda e nem discorda

4. Discorda

5. Discorda muito

29. A sociedade cooperativa oferta serviços de forma gratuita decorrente de fontes de recursos governamentais como a subvenção econômica concedida ao produtor rural e/ou sua cooperativa, a exemplo do PEPRO - Prêmio Equalizador Pago ao Produtor.

1. Concorda muito

2. Concorda

3. Nem concorda e nem discorda

4. Discorda

5. Discorda muito

30. O cooperado sempre tem vantagem de comercializar sua produção por intermédio da sociedade cooperativa.

1. Concorda muito

2. Concorda

3. Nem concorda e nem discorda

4. Discorda

5. Discorda muito

31. A cooperação entre a sociedade cooperativa e o cooperado sempre produz ganho indireto de difícil avaliação monetária.

1. Concorda muito

2. Concorda

3. Nem concorda e nem discorda

4. Discorda

5. Discorda muito

32. O aumento do número de cooperados em uma sociedade cooperativa é fator limitante à oferta de serviços de forma gratuita.

1. Concorda muito

2. Concorda

3. Nem concorda e nem discorda

4. Discorda

5. Discorda muito 


\section{APÊNDICE 3 - Termo de Consentimento de Livre Esclarecimento (TCLE)}

\section{Prezado (a) Senhor (a)}

Pedro Einstein dos Santos Anceles, do Curso de Doutorado em Administração, na Faculdade de Administração, Economia e Contabilidade (FEA) da Universidade de São Paulo (USP) está realizando uma pesquisa científica. Para o alcance do problema definido no projeto de pesquisa é imprescindível à obtenção de informações e dados a serem fornecidos por técnicos especialistas e cooperados integrantes da sociedade cooperativa de produção agropecuária.

Dessa forma, solicita suas ordens no sentido de disponibilizar, o mínimo de tempo possível, para as entrevistas com os técnicos especialistas, e coleta dos questionários a serem respondidos pelos cooperados. Igualmente, esclarece-se que a pesquisa segue as regras de comportamento ético respeitando a confiabilidade dos dados e informações fornecidos.

A leitura do presente texto é muito importante porque esclarece todas as dúvidas a julgar necessárias.

Título da Tese: Sociedade Cooperativa de Produção Agropecuária: Estudo dos Ganhos Indiretos dos Cooperados

Pesquisador: Pedro Einstein dos Santos Anceles, doutorando em Administração pela FEA/USP e Professor Adjunto da Universidade Federal de Santa Maria - RS. E-mail pedroanceles@terra.com.br, e Telefone: (051) 99741464.

Orientador da Pesquisa de Doutorado: Professor Dr. Cláudio Antônio Pinheiro Machado Filho da FEA - Universidade de São Paulo.

\section{Descrição do Projeto de Pesquisa}

O projeto de pesquisa tem como questão central investigar quais as diferentes maneiras pelas quais a sociedade cooperativa de produção agropecuária adiciona valor econômico e social para o cooperado, no espaço temporal anual, em que se desenvolvem as atividades operacionais dessa organização. O tema pesquisado é contemporâneo, apresenta empatia e interesse dos principais integrantes das organizações cooperativas. A matéria é complexa e desperta curiosidade dos pesquisadores, da comunidade científica em geral, e demais entidades públicas e privadas.

A pesquisa é muito útil e a sua participação é de grande valor, haja vista, a lacuna existente no tema sobre a prestação de serviços de forma gratuita ao cooperado, proporcionando ganho indireto a ser mensurado. Ressalva-se, que os dados não serão analisados de forma individual, e sim, serão tabulados em conjunto, de forma que o nome do entrevistado/cooperado e as respectivas respostas, não serão apresentadas no trabalho. Portanto, a pesquisa ganha o merecido relevo no ambiente econômico visando demonstrar as particularidades da riqueza produzida pelo cooperado.

\section{São Paulo, fevereiro de 2014}

\section{Pedro Einstein dos Santos Anceles}

\section{Consentimento de Participação e Assinatura do Entrevistado}

Tendo examinado e compreendido o texto acima descrito, eu concordo de livre espontânea vontade em participar da pesquisa dirigida por Pedro Einstein dos Santos Anceles, doutorando em Administração FEA/USP - Universidade de São Paulo.

\begin{tabular}{|l|l|l|}
\hline Data & Nome do Entrevistado & Assinatura \\
\hline & & \\
\hline
\end{tabular}

